\title{
Páros összehasonlítás mátrixok a többszempontú döntéselméletben
}

\author{
Ábele-Nagy Kristóf
}

2019 
Operációkutatás és Aktuáriustudományok Tanszék

\author{
Témavezetô: \\ Dr. Bozóki Sándor Ph. D.
}

(c) Ábele-Nagy Kristóf 


\section{Budapesti Corvinus Egyetem}

Általános és kvantitatív közgazdaságtan Doktori Iskola

Páros összehasonlítás mátrixok a többszempontú döntéselméletben

Doktori értekezés

Ábele-Nagy Kristóf

Budapest, 2019 



\section{Tartalomjegyzék}

1. Bevezetés 4

1.1. Az értekezés célja . . . . . . . . . . . . . . . . 4

1.2. Az értekezés felépítése . . . . . . . . . . . . . . 4

1.3. Önálló eredmények . . . . . . . . . . . . . . 6

2. A preferenciák számszerüsítése páros összehasonlítások alap$\begin{array}{ll}\text { ján } & 8\end{array}$

2.1. Többszempontú döntések . . . . . . . . . . 8

2.2. Páros összehasonlítás mátrixok . . . . . . . . . 15

2.3. Súlyvektor számítási módszerek . . . . . . . . . . . 20

2.3.1. Sajátvektor módszer . . . . . . . . . 20

2.3.2. Legkisebb négyzetek módszere . . . . . . . . . . 21

2.3.3. Logaritmikus legkisebb négyzetek módszere . . . . . 22

2.3.4. További súlyvektor számítási módszerek . . . . . . 24

2.4. Inkonzisztencia indexek . . . . . . . . . . . . . . 34

2.4.1. A $C R$ index ................ 35

2.4.2. A $C M$ index ............... 38

2.4.3. A GCI index ................ . . 41

2.4.4. Távolságminimalizáló módszerek indexei . . . . . . . 42

2.5. Nem teljesen kitöltött páros összehasonlítás mátrixok ... 44

2.5.1. Gráf reprezentáció _. . . . . . . . . . 47 
2.5.2. Súlyvektor számítási módszerek a nem teljesen kitöltött mátrixok esetében . . . . . . . . . . . 49

2.6. Páros összehasonlítás mátrixok és a mértani közép . . . . . . . 57

2.7. Az Analytic Hierarchy Process . . . . . . . . . . . . . 60

3. Páros összehasonlítás mátrixok gazdasági alkalmazásai $\quad 65$

3.1. Irodalmi áttekintés . . . . . . . . . . . . . 65

3.2. Autóbuszos tömegközlekedés minőségének modellezése . . . . . . . . . . . . . . . 68

4. Pareto-hatékonyság 72

4.1. Egy elemtôl eltekintve konzisztens páros összehasonlítás mát-

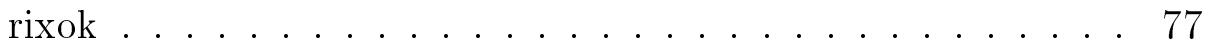

4.2. Két elemtól eltekintve konzisztens páros összehasonlítás mát-

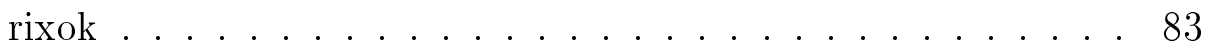

5. A sajátvektor számítása ciklikus koordináták módszerével 92

5.1. Optimális kitöltés Newton-módszerrel _. . . . . . . . . . 93

5.1.1. Egyváltozós Newton-módszer . . . . . . . . . . . 93

5.1.2. Többváltozós Newton-módszer _ . . . . . . . . . 97

5.2. Pozitív mátrixok domináns sajátvektora ciklikus koordinátákkal 98

6. Összefoglalás 


\section{Köszönetnyilvánítás}

Szeretném hálás köszönetemet kifejezni témavezetőmnek, Bozóki Sándornak, a dolgozat létrejöttéhez nyújtott rengeteg segítségéért, az egyetemi és a doktori képzés évei alatti útmutatásáért, valamint azért, hogy felkeltette az érdeklődésemet a téma iránt.

Szintén köszönettel tartozom társszerzôimnek, Bozóki Sándornak, Fülöp Jánosnak és Rebák Örsnek a közös munkáért, illetve a cikkek megjelenéséhez nyújtott segítségükért.

Köszönöm azoknak, akik szintén valamilyen módon hozzájárultak az eredményeink megszületéséhez: Farkas Andrásnak, aki Rebák Örs szakdolgozatának kapcsán nyújtott hasznos meglátásokat, melyeket késóbb a közös cikkbe is be tudtunk építeni, illetve Temesi Józsefnek, aki a Bozóki Sándorral közös cikkünk alapötletét adta.

Köszönet illeti továbbá a BCE Általános és Kvantitatív Közgazdaságtan Doktori Iskoláját és az OTKA K 111797: Páros összehasonlítás alapú preferenciamodellezés és rangsorolás projektjét, valamint az MTA SZTAKI Mérnöki és Üzleti Intelligencia Kutatólaboratórium Operációkutatás és Döntési Rendszerek Kutatócsoportját a kutatásaim és konferencia-részvételeim támogatásáért. 


\section{1. fejezet}

\section{Bevezetés}

\subsection{Az értekezés célja}

Az értekezésem célja a többszempontú döntéselmélet témakörébe tartozó páros összehasonlítás mátrixok és a hozzájuk kapcsolódó fogalmak és alkalmazások, valamint az ezen a téren elért új eredményeim bemutatása. A páros összehasonlítás mátrixok a preferenciamodellezés eszközei, melyek a bonyolult, többtényezôs szubjektív problémákban és rangsorolási feladatokban egyaránt alkalmazhatók.

\subsection{Az értekezés felépítése}

A 2. fejezetben a páros összehasonlítás mátrixokat és a kapcsolódó fogalmakat mutatom be. A 2.1. alfejezetben a többszempontú döntésekrôl és döntési módszerekrôl írok általánosságban, majd ezután a 2.2. alfejezetben a páros összehasonlítás mátrixok bevezetése következik. A 2.3. alfejezet arról szól, milyen módszerekkel lehet egy páros összehasonlítás mátrixból egy súlyvektort kiszámolni, aminek a segítségével a döntési probléma már elemezhető. A páros összehasonlítás mátrix és a súlyvektor közötti transzformáció teszi lehetôvé a páros összehasonlítás mátrixok módszertanának alkalmazását a 
többszempontú problémákra. A következő, 2.4. alfejezetben inkonzisztencia indexeket mutatok be, melyek a döntéshozó által szolgáltatott preferencia információ megbízhatóságát hivatottak mérni. A páros összehasonlítás mátrixok kiterjesztését a hiányos információs esetre, azaz a nem teljesen kitöltött páros összehasonlítás mátrixok módszertanát a 2.5. alfejezetben mutatom be. A 2.6. alfejezetben a páros összehasonlítások és a mértani közép közti kapcsolatra világítok rá, végül pedig a 2.7. alfejezetben az Analytic Hierarchy Process-ról esik szó, amelynek a páros összehasonlítás mátrixok népszerúségét és a mai napig egyik legfontosabb felhasználási területét köszönhetjük.

A 3. fejezetben a páros összehasonlítások gazdasági alkalmazásainak sokrétúségét mutatom be. Ennek érdekében a 3.1. alfejezetben egy gazdasági alkalmazásokkal kapcsolatos irodalmi áttekintést végzek, a 3.2. alfejezetben pedig egy konkrét, a tömegközlekedés minőségével kapcsolatos alkalmazást mutatok be.

A következő, 4. fejezet már új eredményeket mutat be. Itt az egyik legelterjedtebb súlyvektor számítási módszer, a sajátvektor módszer által számolt súlyvektor hatékonyságát vizsgáljuk, tehát azt, hogy mennyire jól becsli a döntéshozó által adott preferencia arányokat. Sajnos a sajátvektor módszer által számolt súlyvektor nem minden esetben Pareto-hatékony, azonban eredményeink alapján bizonyos, gyakorlatban is lényeges esetekben mégis biztosítható a hatékonyság. Elôször a 4.1. alfejezetben az egy elemtól eltekintve konzisztens páros összehasonlítás mátrixok esetére látjuk be a sajátvektor Pareto-hatékonyságát, majd ezt az eredményt a 4.2. alfejezetben kiterjesztjük a két elemtôl eltekintve konzisztens mátrixok esetére is.

Az 5. fejezetben szintén új eredmények kerülnek bemutatásra. Ebben a fejezetben is a sajátvektor módszer a vizsgált súlyvektor számítási módszer. Mindkét, ebben a fejezetben szereplô új eljárás a ciklikus koordináták módszerének segítségével számolja ki a sajátvektor módszer súlyvektorát, azaz a domináns sajátvektort. Az 5.1. alfejezetben nem teljesen kitöltött páros összehasonlítás mátrixok sajátvektor módszer szerinti kitöltését számoljuk 
egy Newton-módszeren alapuló iteratív eljárással. Ez az 5.1.1. alfejezetben bemutatott módon egyváltozós Newton-módszerrel ciklikus koordináták segítségével, illetve az 5.1.2. alfejezetben leírtak alapján többváltozós Newtonmódszerrel is lehetséges. A többváltozós Newton-módszer ugyan nem a ciklikus koordináták módszerét használja, de szorosan kötődik az egyváltozós változathoz. Az 5.2. alfejezetben egy másik új iteratív eljárást mutatok be pozitív mátrixok domináns sajátértékének és sajátvektorának számítására. Ez az eljárás a páros összehasonlítás mátrixoknál is szélesebb körben alkalmazható, melyeket speciális esetként tartalmazza. Végül a 6. fejezetben az összefoglalás és a konklúzió zárja az értekezést.

\section{3. Önálló eredmények}

Az értekezésben bemutatott új eredmények közül az alábbiakban felsorolom a saját hozzájárulásaimat a közös cikkekhez.

A 4.1. alfejezetben bemutatott, Bozóki Sándorral közös Efficiency analysis of simple perturbed pairwise comparison matrices címú [3] cikkben a saját hozzájárulásaim:

- Az (5)-(6) (az értekezésben (4.4) és (4.5)) sajátvektor formulák ellenórzése.

- A 3.1., 3.2., 3.3. Lemmák (az értekezésben 1., 2. és 3. Lemma) bizonyítása és annak felismerése, hogy a 3.1. Lemma az (5) formulából, a 3.2. Lemma az (5) és (6), a 3.3. Lemma pedig a (6) formulából vezethetô le.

- Részvétel a cikk szerkesztésében.

A 4.2. alfejezetben bemutatott, Bozóki Sándorral és Rebák Örssel közös Efficiency analysis of double perturbed pairwise comparison matrices címú [4] cikkben a saját hozzájárulásaim: 
- A $2 \mathrm{a}-2 \mathrm{j}$ és $3 \mathrm{a}-3 \mathrm{~h}$ lemmák bizonyítása, valamint az összes lemma bizonyításának ellenôrzése.

- A (9)-(21) sajátvektor formulák ellenôrzése.

- Remark 5 és bizonyítása.

- A legfeljebb két elem megváltoztatásával konzisztenssé tehetô páros összehasonlítás mátrixok relevanciájának vizsgálata (az Introduction fejezetben).

- A cikk szerkesztése.

Az 5.1. alfejezetben bemutatott egyszerzős saját Minimization of the Perron eigenvalue of incomplete pairwise comparison matrices by Newton iteration címú [2] cikkel kapcsolatban köszönettel tartozom Bozóki Sándornak a probléma felvetéséért és a cikk írásában nyújtott segítségéért.

Az 5.2. alfejezetben bemutatott, Fülöp Jánossal közös On computing the principal eigenvector of positive matrices by the method of cyclic coordinates címú [5] cikkben a saját hozzájárulásaim:

- Az algoritmushoz tartozó alapvetô képletek kiszámítása.

- Az algoritmus implementálása ( $\mathrm{C}++$ környezetben).

- A számpéldák és az ábrák készítése.

- A cikk szerkesztése.

A fentieken túl az értekezés 2.5. alfejezetében szereplő 1. Állítás is új eredmény, melynek a kérdését én vetettem fel, a bizonyítását pedig Bozóki Sándor végezte. 


\section{2. fejezet}

\section{A preferenciák számszerüsítése páros összehasonlítások alapján}

\subsection{Többszempontú döntések}

Döntési szituációban vagyunk minden olyan esetben, amikor egynél több lehetséges alternatíva közül kell választanunk. Ez lehet egyszerúen a legjobb alternatíva kiválasztása, de előfordul, hogy rangsorolnunk kell az alternatívákat. Néha a probléma leegyszerúsíthető egyetlen szempont szerinti döntésre, például lehetséges, hogy egy vállalat csak a profit szempontjából vizsgál meg mindent. Ilyen esetekben egy szempontú döntési problémánk van, azaz egy célfüggvényt kell minimalizálni vagy maximalizálni, amelyet az operációkutatás hagyományos eszköztárával oldhatunk meg. Azonban még egy olyan, látszólag egyszerú célfüggvény, mint a profit sem biztos, hogy leegyszerûsíthetô egyetlen szemponttá, hiszen ezt is számos tényezô befolyásolhatja. Ha ezt az egyszerúsítést nem áll módunkban megtenni, akkor egy többszempontú döntési problémával állunk szemben.

Hasonló a helyzet, ha mindent a hasznosság, avagy a végsố megelégedés szempontjából vizsgálunk. Ugyan egy racionális döntéshozó végsô célja mindig a legnagyobb hasznosságot nyújtó alternatíva kiválasztása, azonban a 
hasznosságot gyakran annyi tényező befolyásolja, hogy nem tudjuk ránézésre megmondani, melyik alternatívára lesz maximális. Ekkor a hasznosságra úgy gondolhatunk, mint a fôszempont, a hasznosságot befolyásoló tényezőkre pedig, mint annak alszempontjai. Ilyen értelemben a többszempontú döntéselmélet célja az absztrakt hasznosságmaximalizálás finomítása egy gyakorlatban könnyebben kezelhetô struktúra létrehozásával.

A mindennapi problémák során nem alkalmazunk komoly módszertant egy-egy kisebb döntés meghozatalakor, mert egyszerúen túl nagy lenne az idő és esetlegesen az erőforrás igénye. Ilyen helyzetekben gyorsan, bejáratott sémák szerint, illetve heurisztikák alapján döntünk. Nagyobb, fontosabb és bonyolultabb döntések esetén azonban érdemes lehet igénybe venni egy olyan megalapozott döntéselméleti módszertant, ami hozzásegít, hogy a problémát részenként elemezzük és értékeljük ki. Egy nagy döntési feladat kisebb részekre való visszavezetése megkönnyíti a pontos értékelést, ezáltal a jobb döntéshozatalt. Ehhez azonban már a mindennapi heurisztikáknál komolyabb apparátusra lehet szükségünk.

A döntéselméleti modellek első lépcsőfoka az úgynevezett elemi döntési módszerek alkalmazása. Ezek olyan egyszerú, de egzakt módszerek, melyek egy nem túl bonyolult, de a heurisztikák alkalmazásánál komolyabb megfontolást igénylő feladatban alkalmazhatóak. Az elemi döntési módszerekból itt csak egy rövid ízelító szerepel, a részletesebb tárgyalást ld. például Temesi: A döntéselmélet alapjai címú könyvében [81].

Ha több szempontunk van (vagy ha úgy tetszik, a végsố megelégedésnek alszempontjai is vannak), akkor azok között vagy fennáll valamilyen átváltás lehetôsége, vagy nem. Ha nem áll fenn az átváltás lehetôsége, akkor az jelentkezhet olyan formában, hogy egy szempont annyira fontos, hogy elsősorban csak az alapján döntünk, és a második legfontosabb szempont csak akkor számít, ha az elsô szerint holtverseny van. Ez a lexikografikus rendezésnek felel meg.

Más elemi döntési módszerek is hasonló elven múködnek. Néhányuk bár- 
milyen döntési feladatban használható, mivel egy előzetes szûrôként funkcionál. Ezeknek a módszereknek a feladata, hogy még a komolyabb modellek alkalmazása előtt eltávolítsa azokat az alternatívákat, amelyek valamilyen szempontból nem felelnek meg. Például minden szempont szerint meghúzhatunk egy minimum szintet, és ha az alternatíva ezek közül valamelyiket nem teljesíti, akkor eltávolítjuk. Ezt az eljárást hívjuk konjunktív szabálynak. A konjunktív szabályhoz hasonló gondolatmenetet követ a diszjunktív szabály. Ekkor azok az alternatívák maradnak versenyben, amelyeknek legalább egy szempont szerint kiemelkedô a teljesítményük. Itt is minden szempont szerint egy-egy (kiválósági) küszöbérték van meghatározva, és az alternatíváknak legalább egy szempont szerint el kell érniük ezt a szintet, a többi szempont szerint nyújtott esetleges rossz teljesítménynek viszont nincsen további következménye.

Egy további, igen alapvetô szưrési eljárás a dominancia-szúrés. Racionális döntéshozó nem választ olyan alternatívát, aminél van egyértelmúen, minden szempont szerint jobb. Az olyan alternatívákat pedig, amelyekre létezik egy másik alternatíva, ami minden szempont szerint legalább ugyanolyan jó, és legalább egy szempont szerint határozottan jobb, dominált alternatíváknak nevezzük. A dominált alternatívák elhagyása a modellból a legtöbb esetben indokolt. Kivételt képezhetnek az olyan esetek, ahol kevés az alternatíva, és a dominált alternatívák segítségével még pontosabban tudjuk modellezni a döntéshozó preferenciáit, például még több összehasonlítást tudunk végezni. Ha kiderül, hogy a döntéshozó mégis szívesebben választott volna egy dominált alternatívát, akkor (a racionalitást továbbra is feltéve) nem vettünk figyelembe elég szempontot. A dominancia-szúrés elônye, hogy nincs szükség hozzá kívülrôl adott küszöbértékekre, csupán a többi alternatíva értékelései alapján elvégezhető.

A szürési módszerek ugyan nagyon hasznosak, de ritkán sikerül csak ezek alapján dönteni. Ennek oka, hogy nem szolgáltatnak sorrendet, és ritka az az eset, hogy csupán egyetlen alternatíva maradna meg a szúrés után. A leg- 
kézenfekvôbb továbblépési mód az elemi döntési módszerek alkalmazása. A két legegyszerúbb módszer az optimista és a pesszimista döntési elv. Ahhoz, hogy ezeket alkalmazni tudjuk, azonos skálára kell az összes szempont szerinti értékeléseket hozni. Ezt megtehetjük például úgy, hogy minden szempont szerint a legjobb értékelésnek 1-es értéket adunk, a többit pedig ehhez viszonyítjuk, ami egy 0 és 1 közötti értéket eredményez. Az optimista avagy maximax elv azt az alternatívát választja, amelynek az összes szempontot figyelembe véve a legjobb értékelése a legerôsebb. A pesszimista, más néven biztonságra törekvô, avagy maximin elv szerint azt az alternatívát választjuk, amelynek a legrosszabb értékelése a legjobb, ezzel biztosítva, hogy semmiból sem lesz túlságosan gyenge.

Az esetek többségében azonban, ahogy ezt a továbbiakban fel is fogjuk tenni, lehetôség van átváltásra. Ez azt jelenti, hogy elnézzük egy alternatívának, hogy egy szempont szerint kevésbé jó, cserébe azért, ha egy másik szempont szerint jobb. Az átváltási arányok kérdése a továbbiakban a legfontosabb kérdéseink közé fog tartozni. Meg kell vizsgálnunk, hogy mennyivel kell az egyes szempontok szerint jobban teljesíteni, ha másokban rontunk. Az átváltási arányok kérdése ugyanaz, mint ha megmondjuk, hogy melyik szempontnak mekkora a súlya a döntésben. Ezt a továbbiakban a szempont fontossági súlyának, röviden súlyának fogjuk nevezni.

Ha a döntéshozó rendelkezésünkre tudja bocsátani, vagy hajlandó a döntéstámogató segítségével megkonstruálni a többszempontú hasznossági függvényét, akkor alkalmazható a többszempontú hasznosságelmélet (angolul Multi-Attribute Utility Theory, röviden MAUT) [48, 51, 88]. A MAUT alkalmazása azonban általában nagyon idő- és információigényes.

Az egyes döntési alternatívák teljesítményét az egyes szempontok szerint külön-külön mérhetjük. Ha ezeket az egyes szempontok szerinti értékeléseket valamilyen módon aggregáljuk, akkor az alternatívák végső döntési értékelését, illetve rangsorát is meghatározhatjuk. Az alternatívák teljesítményét mérhetjük valamilyen abszolút vagy relatív skálán. A relatív skálán való mé- 
résre egy módszer a páros összehasonlítások módszere, ami során egyszerre mindig két alternatívát hasonlítunk össze. A későbbiekben ezt a megközelítést vesszük majd alapul. A relatív skálára is két természetes megközelítés adódik, a különbség-, illetve az arányskála. A páros összehasonlítások különbségskáláját használja a MACBETH (Measuring Attractiveness by a Cathegorical Based Evaluation Technique) [32], míg az arányskálát a 2.7. alfejezetben tárgyalt AHP (Analytic Hierarchy Process) [69] módszer. Az értekezés további fejezeteiben az arányskálát fogjuk alapul venni.

Egy másik igen jelentős döntéselméleti módszercsalád az „outranking” módszerek csoportja. Ezek körében a klasszikus értelemben vett átválthatóságra nincs lehetőség. Ugyan a szempontoknak vannak fontossági súlyai, de az alternatívákon meghatározott „outranking” preferencia relációból indulunk ki. Ez a reláció úgy adódik, hogy egy alternatíva jobb egy másiknál, ha az ezt alátámasztó szempontok többen vannak, vagy súlyozva erôsebbek, mint az ezt cáfoló szempontok. Ennek az elvnek a konkrét megvalósítása már magától az adott módszertől függ. A módszerek némelyike megengedi két alternatíva összehasonlíthatatlanságát és csak részleges rangsort ad, míg mások nem engedik meg és teljes rangsort szolgáltatnak eredményül. A két legjelentősebb outranking módszercsalád az ELECTRE és a PROMETHEE. Részletes összefoglalók megtalálhatóak magyar nyelven például Temesi [81] könyvében, illetve angol nyelven például Ishizaka és Nemery [48] könyvében. Mindkét módszercsalád különbségskálát használ, a [0,1] intervallum elemeit használja a preferencia intenzitásának számszerúsítésére, továbbá mindkettốben meg lehet határozni indifferencia, illetve preferencia küszöböket. Az indifferencia küszöb azt ragadja meg, hogy bizonyos apró különbségeket még elhanyagolhatónak tekinthetünk, azonban ugyanazon szempont szerint a különbségek nem összeadhatóak. Például két termék ára között mondhatjuk, hogy 500Ft különbség még nem számít, de 1000Ft már igen. Ekkor ha az A alternatíva 5000Ft-ba kerül, a B 5500Ft-ba, a C pedig 6000Ft-ba, akkor a B az ár szempontjából indifferens mindkét másikkal, az A a C-vel viszont már 
nem. Hasonlóan múködik a preferencia küszöb is, ekkor azt mondjuk, hogy az egyik alternatíva ezen a különbségen túl már egyértelmúen preferált a másikhoz képest. Az ELECTRE módszereknél ezen kívül még egy vétó küszöböt is meg kell határozni, amely tulajdonképpen az indifferencia küszöb tükörképe. Az indifferencia küszöb akkor lép életbe, amikor azt vizsgáljuk, hogy egyetérthetünk-e azzal, hogy A jobb B-nél egy bizonyos szempont szerint. Ha az elôny B számára nem haladja meg az indifferencia küszöböt, akkor a válasz igen. Ugyanezt a szerepet a vétó küszöb tölti be akkor, amikor azt vizsgáljuk, hogy cáfolható-e ugyanez az állítás. Ha az elôny B számára nagyobb, mint a vétó küszöb, akkor cáfolható.

Egy további megközelítési lehetôség valamilyen cél vagy referenciaszint alapján történő döntéshozatal. Ilyen megközelítést képvisel például a célprogramozás, illetve a TOPSIS módszer. A TOPSIS (Technique of Order Preference Similarity to the Ideal Solution) [46] módszer alapja, hogy egy ideális és egy anti-ideális alternatívától való távolságot vizsgálja. Az lesz a legjobb alternatíva, amelyik az ideálishoz a legközelebb, az anti-ideálistól pedig a legtávolabb van. Elôször az alternatívák egyes szempontok szerinti teljesítményét kell kardinálisan értékelni, majd ezeket az értékeléseket valamilyen normalizálással egy skálára kell hozni. A normalizálás tipikusan az ideális módszerrel, ahol szempontonként a szempont legjobb alternatívájának értékelésével osztjuk a többi alternatíváét, vagy a disztributív módszerrel történik, amely esetén az értékeléseket a szempont szerinti értékelések négyzetösszegének gyökével osztjuk le. Ezután a szempontok a döntéshozó által előre meghatározott súlyaival beszorozva megkapjuk a végső értékeléseket az egyes szempontok szerint, melyek a [0,1] skálán helyezkednek el. A következô lépésben az alternatívák távolságát kell meghatározni az ideális és az anti-ideális alternatíváktól. Az ideális (illetve az anti-ideális) alternatíva meghatározása is történhet több módon. Az egyik, hogy minden szempont szerint vesszük a legjobb rendelkezésre álló végső értékelést, és ezt adjuk az ideális alternatíva értékelésének. A másik lehetőség, hogy minden szempont 
szerint 1-es, azaz maximális értékelést adunk az ideális alternatívának. Egy további lehetôség, hogy a döntéshozó határoz meg egy ideális alternatívát, ennek az elôző két módszer értéke között kell lennie minden szempont szerint, azonban ez plusz információt igényel a döntéshozótól. Az ideális és anti-ideális alternatívától való távolságot is több módon lehet mérni, például négyzetes vagy abszolút normában. Végül minden alternatívára kiszámoljuk a közelségi együtthatót, az anti-ideális ponttól vett távolságot osztva az ideális és az anti-ideális ponttól számolt távolság összegével, és a legnagyobb együtthatójú alternatívát választjuk gyôztesnek.

A többszempontú döntéselmélet (angolul Multi-Criteria Decision Making, röviden $\mathrm{MCDM}$ ) a konkrét alkalmazott módszertantól függetlenül a döntéshozó preferenciáinak modellezéséról szól. Ilyen bonyolult kérdésekben a döntéshozó általában nem tud annyi szempontot akkurátusan figyelembe venni, a szempontok fontosságait közvetlenül megfelelóen meghatározni, hogy végül a saját szubjektív preferenciáinak legmegfelelőbb döntés szülessen. Ebben a döntéselméleti módszertanok alkalmazásával segíthetjük a döntéshozót, ezért ezt a tudományterületet többszempontú döntéstámogatásnak (Multi-Criteria Decision Aid, MCDA) is nevezik. Az MCDA rövidítés olykor a Multi-Criteria Decision Analysis rövidítéseként szerepel, mely tulajdonképpen ugyanazt takarja, mint az MCDM. A többszempontú döntéselmélet nem kizárólag egy döntéshozó egy döntésben való támogatásáról szól, hanem például csoportos döntésekkel, bizonytalanság melletti döntéshozatallal és alternatívák más szituációban történô rangsorolásával is foglalkozik, illetve jelentôs tematikai átfedés tapasztalható a szavazások és társadalmi döntések elméletével.

Egy többszempontú döntési problémát elő kell készíteni. Meg kell határozni a szóba jöhetô szempontokat és alternatívákat. Szintén meg kell határozni, hogy mennyire legyen részletesen lebontva kisebb kérdésekre a feladat, annak struktúráját meg kell határozni. Nem érdemes túl apró részletekbe menően meghatározni a feladatot, mert áttekinthetetlenné és túl időigényessé válhat. Szintén nem érdemes túl egyszerúen, például túl tág szempontok- 
kal meghatározni a feladatot, mert ez a pontosság rovására mehet. Továbbá gondoskodni kell róla, hogy azok a feltételek, amelyek mellett a választott módszertant alkalmazni kívánjuk, fennállnak.

Összefoglalva tehát, ha az alkalmazandó döntési módszer kiválasztásra került, egy többszempontú döntési feladat megoldása a következôképpen történik [68, I.1.8. fejezet]: Elôször meg kell határozni a célt, a figyelembe veendố szempontokat és a szóba jövô alternatívákat. Ezután következik az így felépített döntési modell megoldása, mely a következô lépésekból áll:

1. Minden alternatíva minden szempont szerinti értékelése.

2. Az összes szempont súlyának meghatározása.

3. A szempontok szerinti alternatíva-értékelések összegzése a szempontsúlyok alapján.

4. A kapott eredmény alapján a legjobb alternatíva vagy alternatívák kiválasztása.

\subsection{Páros összehasonlítás mátrixok}

Ebben a fejezetben a Saaty [69] által bevezetett páros összehasonlítás mátrixokról lesz szó, az itt szereplő fogalmak és állítások megtalálhatóak Saaty könyvében [70], valamint például Rapcsák jegyzetében [68] és Temesi könyvében [81].

Gyakran előfordul, hogy alternatívák értékeléseinél vagy a szempontok fontossági súlyainak meghatározásánál nem állnak közvetlenül rendelkezésünkre maguk a számszerú értékek, csupán azok arányaira vannak becsléseink. Például nem valószínú, hogy egy döntéshozó sok szempont esetén kellô bizonyossággal meg tudja mondani, hogy az egyes szempontok milyen súllyal befolyásolják a döntését. A szempontok súlyainak viszonyát azonban általában jobban tudja a döntéshozó becsülni. Amennyiben a viszonyok arányok, 
akkor a kérdés, melyre a döntéshozónak minden szempontpár esetén válaszolnia kell, az, hogy hányszor fontosabb az egyik szempont a másiknál. Ebben az esetben tehát kardinális összehasonlításokról van szó, a válaszok konkrét számértékek. Az arányokból $n$ összehasonlítandó elem esetén egy $n \times n$ es páros összehasonlítás mátrixot alkothatunk (angolul pairwise comparison matrix, röviden PCM):

1. Definíció. Az $\mathbf{A}=\left[a_{i j}\right]_{i, j=1, \ldots, n} \in \mathbb{R}_{+}^{n \times n}$ mátrixot páros összehasonlítás mátrixnak nevezzük, ha

1. $a_{i j}>0$ és

2. $a_{i j}=1 / a_{j i}$,

minden $i, j=1, \ldots, n$ indexpár esetén.

A második tulajdonságból következik, hogy $a_{i i}=1$. Az $n \times n$-es páros összehasonlítás mátrixok halmazát $\mathcal{P C} \mathcal{M}_{n}$-el jelöljük.

Egy $\mathbf{A} \in \mathcal{P C} \mathcal{M}_{n}$ páros összehasonlítás mátrix általános alakban tehát a következôképpen írható fel:

$$
\mathbf{A}=\left(\begin{array}{ccccc}
1 & a_{12} & a_{13} & \ldots & a_{1 n} \\
a_{21} & 1 & a_{23} & \ldots & a_{2 n} \\
a_{31} & a_{32} & 1 & \ldots & a_{3 n} \\
\vdots & \vdots & \vdots & \ddots & \vdots \\
a_{n 1} & a_{n 2} & a_{n 3} & \ldots & 1
\end{array}\right) .
$$

Az $a_{i j}$ értékek egy ilyen mátrixban tehát például azt jelenthetik (más lehetséges jelentéseket ld. később), hogy az $i$ szempont hányszor fontosabb a $j$ szempontnál. Ha a kardinális tranzitivitási tulajdonság is teljesül egy páros összehasonlítás mátrixra, akkor konzisztensnek nevezzük:

2. Definíció. Az $\mathbf{A} \in \mathcal{P C} \mathcal{M}_{n}$ páros összehasonlítás mátrix konzisztens, ha

$$
a_{i k} a_{k j}=a_{i j}
$$

minden $i, j, k=1, \ldots, n$ indexhármasra. 
Konzisztens mátrix esetén tehát, ha például az A szempont 2-szer fontosabb a B szempontnál, a B pedig 3-szor fontosabb a C-nél, akkor A 6-szor fontosabb C-nél. Az $n \times n$-es konzisztens páros összehasonlítás mátrixok halmazát $\mathcal{P C} \mathcal{M}_{n}^{*}$-al jelöljük.

Egy páros összehasonlítás mátrixot inkonzisztensnek nevezünk, ha nem konzisztens, azaz:

3. Definíció. Egy $\mathbf{A} \in \mathcal{P C} \mathcal{M}_{n}$ páros összehasonlítás mátrix inkonzisztens, ha legalább egy $i, j, k=1, \ldots, n$ indexhármasra

$$
a_{i k} a_{k j} \neq a_{i j}
$$

Egy $\mathbf{A} \in \mathcal{P C} \mathcal{M}_{n}^{*}$ konzisztens páros összehasonlítás mátrix $a_{i j}$ elemeit $a_{i j}=\frac{w_{i}}{w_{j}}$ alakban is felírhatjuk, mert ekkor $\frac{w_{i}}{w_{k}} \frac{w_{k}}{w_{j}}=\frac{w_{i}}{w_{j}}$ miatt az alábbi általános alakú mátrixra teljesül a 2. Definícióbeli (2.2) összefüggés:

$$
\mathbf{A}=\left(\begin{array}{ccccc}
1 & \frac{w_{1}}{w_{2}} & \frac{w_{1}}{w_{3}} & \ldots & \frac{w_{1}}{w_{n}} \\
\frac{w_{2}}{w_{1}} & 1 & \frac{w_{2}}{w_{3}} & \ldots & \frac{w_{2}}{w_{n}} \\
\frac{w_{3}}{w_{1}} & \frac{w_{3}}{w_{2}} & 1 & \ldots & \frac{w_{3}}{w_{n}} \\
\vdots & \vdots & \vdots & \ddots & \vdots \\
\frac{w_{n}}{w_{1}} & \frac{w_{n}}{w_{2}} & \frac{w_{n}}{w_{3}} & \ldots & 1
\end{array}\right)
$$

Az $x_{i}=w_{1} / w_{i-1}, i=2,3, \ldots, n$ jelöléssel a (2.3) alakkal ekvivalens a következô felírás:

$$
\mathbf{A}=\left(\begin{array}{ccccc}
1 & x_{1} & x_{2} & \ldots & x_{n-1} \\
\frac{1}{x_{1}} & 1 & \frac{x_{2}}{x_{1}} & \ldots & \frac{x_{n-1}}{x_{1}} \\
\frac{1}{x_{2}} & \frac{x_{1}}{x_{2}} & 1 & \ldots & \frac{x_{n-1}}{x_{2}} \\
\vdots & \vdots & \vdots & \ddots & \vdots \\
\frac{1}{x_{n-1}} & \frac{x_{1}}{x_{n-1}} & \frac{x_{2}}{x_{n-1}} & \ldots & 1
\end{array}\right)
$$

amelyet a 4. fejezetben alkalmazni is fogunk. A (2.3) és (2.4) alakok ekvivalenciája abból következik, hogy egy konzisztens mátrix egyértelmúen meghatározott tetszóleges, így például az elsô sorának elemei által. Ez onnan 
látható, hogy a (2.3) alakban az $i$. sor az elsô sor $w_{i} / w_{1}$-szerese, így a mátrix rangja 1.

Páros összehasonlítás mátrixot tulajdonképpen bármilyen, aránnyal történô összehasonlítás esetén használhatunk. A leggyakoribb felhasználási módjai:

- Szempontok súlyai,

- Alternatívák értékelései,

- Események valószínúségei,

- Csoportos döntéshozatalban a döntéshozók szavazóerôi.

Néhány további, ritkábban használt értelmezési lehetőség [19]:

- Átváltási arányok,

- Az adott szempont szerinti átlagos értékelések relatív hozzájárulása,

- A szempontok megkülönböztetô ereje az alternatívákon,

- Az optimális alternatíva esetén a szempont hozzájárulása a végsố pontszámhoz,

- A szempont által hordozott relatív információtartalom.

A továbbiakban általában szempontok súlyaival illusztráljuk a páros összehasonlítás mátrixok szerepét.

A célunk tehát az, hogy a szempontok páros összehasonlításait alkalmazva megkapjuk az egyes szempontok súlyait, pontosabban azok becslését a döntési szituációban, melyek vektora az úgynevezett súlyvektor. A döntéshozó preferenciáit a szempontok valódi súlyai testesítik meg, ezt azonban nehéz számszerúsíteni, ezért alkalmazzuk a páros összehasonlítás mátrixok 
módszertanát. A súlyvektort tekintjük a döntéshozó (szempont-) preferenciáinak végső becsléseként. A súlyvektor meghatározására több módszer is van, melyeket a 2.3. alfejezetben tárgyalunk.

A cél az, hogy a w > 0 súlyvektor elemeit úgy határozzuk meg, hogy (valamilyen értelemben) a lehető legközelebb legyenek a páros összehasonlítás mátrix elemeihez, azaz a súlyarányokra adott becslésekhez. Konzisztens esetben nincsenek nehézségek, a $\mathbf{w}=\left(w_{1}, w_{2}, \ldots, w_{n}\right)^{\top}$ súlyvektort tökéletesen közelíti a (2.3)-ban adott mátrix.

Fordított gondolatmenettel egy w súlyvektor elemeinek arányaiból mindig konstruálható egy (2.3) alakú konzisztens páros összehasonlítás mátrix. Így azt is mondhatjuk, hogy inkonzisztens esetben az inkonzisztens páros összehasonlítás mátrixot próbáljuk közelíteni egy konzisztens mátrixszal, melybôl egyértelmúen számolható a súlyvektor. Ez ugyanaz, mint a közvetlen megközelítés, miszerint egy inkonzisztens mátrixból valamilyen módszerrel közvetlenül számoljuk a súlyvektort.

A súlyvektor elemei mindig pozitívak. Ha egy szempont súlya (vagy a valószínűségeket becslő modellkeretben egy esemény valószínúsége) 0 lenne, akkor azt elhagyhatnánk a modellból. Egy súlyvektor bármely pozitív konstanssal szorozva is ugyanaz a súlyvektor, mert csak az arányoknak van jelentôségük. A konstanssal megszorzott súlyvektorból is ugyanaz a konzisztens páros összehasonlítás mátrix adódik. Így valamilyen normalizálás szükségeltetik, leginkább a konkrét feladathoz igazítandó értelmezési megfontolások alapján. A szokásos normalizálás a

$$
\sum_{i=1}^{n} w_{i}=1,
$$

azaz amikor a súlyvektor elemeinek összegét választjuk 1-nek. Ez különösen praktikus, ha százalékokról beszélünk, például, hogy a döntési szituációban az adott szempont hány százalékban befolyásolja a döntést. Szintén ez a normalizálás célszerú valószínúségek esetén, mivel ez biztosítja, hogy a valószínúségek összege 1 legyen, azaz eloszlást kapjunk. Továbbá ez a szokásos 
eljárás olyan esetekben, amikor a konkrét normalizálásnak nincs különösebb jelentősége. Egy másik, gyakran használt normalizálás a

$$
w_{1}=1
$$

azaz amikor az első elem súlyát választjuk referenciának. Ha a szempontokat átsorszámozzuk, akkor bármelyik szempont lehet az elsô, így annak csak technikai jelentősége van, hogy melyik szempontot választjuk referenciának. Ha csak rangsorolásra használjuk a súlyvektort, akkor a normalizálásnak nincsen jelentősége.

\subsection{Súlyvektor számítási módszerek}

Egy súlyvektor számítási módszer egy olyan eljárás, amellyel egy páros összehasonlítás mátrixból kiszámolható a súlyvektor. Formálisan egy súlyvektor számítási módszer egy $f: \mathcal{P C} \mathcal{M}_{n} \rightarrow \mathbb{R}_{+}^{n}$ függvény, ahol $\mathbb{R}_{+}^{n}$ az $n$ dimenziós pozitív valós vektorok halmaza. Mivel egy $\mathbf{A} \in \mathcal{P C} \mathcal{M}_{n}^{*}$ konzisztens páros összehasonlítás mátrix felírható $\mathbf{A}=\left[w_{i} / w_{j}\right]_{i, j=1, \ldots, n}$ alakban, ezért általános elvárás, hogy egy súlyvektor számítási módszer ebben az esetben ezt a $\mathbf{w}=\left(w_{1}, \ldots, w_{n}\right)^{\top}$ vektort rendelje a mátrixhoz, normalizálástól eltekintve. Formálisan: ha $\mathbf{A} \in \mathcal{P} \mathcal{C} \mathcal{M}_{n}^{*}$, akkor $f(\mathbf{A})=c \mathbf{w}$, ahol $c>0$.

A következô alfejezetekben a legelterjedtebb, egyben a továbbiak szempontjából leglényegesebb három módszert tárgyaljuk részletesen. Ezek a sajátvektor módszer, a legkisebb négyzetek, valamint a logaritmikus legkisebb négyzetek módszere, kiegészítve néhány további súlyvektor számítási módszerrel.

\subsubsection{Sajátvektor módszer}

A sajátvektor módszer (angolul Eigenvector Method, röviden EM) a legrégebbi súlyvektor számítási módszer, Saaty a páros összehasonlítás mátrixokkal együtt az 1977-es cikkében vezette be [69]. 
A (2.3) és különösen a (2.4) alakból látható, hogy egy $\mathbf{A} \in \mathcal{P} \mathcal{C} \mathcal{M}_{n}^{*}$ konzisztens páros összehasonlítás mátrix rangja 1. A (2.3) alakban felírt mátrix esetén az $i$. sor az elsô sor $w_{i} / w_{1}$-szerese. Hasonlóan, a (2.4) alakot használva az $i$. sor az elsố $1 / x_{i-1}$-szerese.

Mivel egy $\mathbf{A} \in \mathcal{P C} \mathcal{M}_{n}^{*}$ mátrix rangja 1, ezért csak egyetlen olyan sajátértéke van, amely nem 0 . Az egyetlen nem 0 sajátérték szükségképpen $n$, azaz a mátrix sorainak vagy oszlopainak száma. Ez az állítás azért igaz, mert $\operatorname{tr}(\mathbf{A})$, azaz a mátrix nyoma (amely a fóátlóbeli elemek összege) a sajátértékek összege. Mivel a főátlóban $n$ darab 1-es áll, ezért $\operatorname{tr}(\mathbf{A})=n$, tehát a sajátértékek összege $n$, és láttuk, hogy közülük csupán egy nem 0 .

A (2.3) alakból látható az is, hogy w éppen az $n$ sajátértékhez tartozó sajátvektora az $\mathrm{A} \in \mathcal{P} \mathcal{C} \mathcal{M}_{n}^{*}$ konzisztens páros összehasonlítás mátrixnak. Így tehát teljesül rájuk az alábbi összefüggés:

$$
\mathbf{A} \mathbf{w}=n \mathbf{w} .
$$

A sajátvektor módszer a fenti tulajdonság általánosításából indul ki.

Mivel egy $\mathbf{A} \in \mathcal{P C} \mathcal{M}_{n}$ páros összehasonlítás mátrix pozitív, ezért a Perron-Frobenius-tétel következtében egyértelmúen létezik legnagyobb (valós) sajátértéke, és a hozzá tartozó, lényegében egyértelmú sajátvektor elemei választhatóak mind pozitívnak. A legnagyobb (avagy domináns) sajátértéket innentôl jelölje $\lambda_{\max }$. A sajátvektor módszer a $\lambda_{\max }$-hoz tartozó jobboldali sajátvektort javasolja súlyvektornak. A sajátvektor módszer által adott megoldást innentôl jelölje $\mathbf{w}^{E M}$, melyre tehát teljesül, hogy

$$
\mathbf{A} \mathbf{w}^{E M}=\lambda_{\max } \mathbf{w}^{E M} .
$$

\subsubsection{Legkisebb négyzetek módszere}

Egy másik megközelítési mód, hogy a mátrixelemeknek a súlyok arányaitól vett távolságát minimalizáljuk. Amennyiben a távolságot négyzetesen mérjük, a legkisebb négyzetek módszeréhez jutunk [20]. A legkisebb négyzetek módszere (angolul Least Squares Method, röviden LSM) tehát azt a 
$\mathbf{w}=\left(w_{1}, w_{2}, \ldots, w_{n}\right)^{\top}$ vektort javasolja súlyvektornak, amely az alábbi optimalizálási feladat megoldása:

$$
\begin{gathered}
\min \sum_{i=1}^{n} \sum_{j=1}^{n}\left(a_{i j}-\frac{w_{i}}{w_{j}}\right)^{2} \\
\sum_{i=1}^{n} w_{i}=1 \\
w_{i}>0, \quad i=1, \ldots, n .
\end{gathered}
$$

A fenti célfüggvény ekvivalens azzal, hogy az $\mathbf{A}$ mátrixot a $\mathbf{W}=\left[\frac{w_{i}}{w_{j}}\right]_{i, j=1, \ldots, n}$ $\in \mathcal{P C} \mathcal{M}_{n}^{*}$ konzisztens mátrixszal közelítjük Frobenius-normában mérve a lehetô legjobban.

Sajnos a (2.9) probléma egy nemkonvex optimalizálási probléma, melynek többszörös lokális és globális optimumai is lehetnek [50].

\subsubsection{Logaritmikus legkisebb négyzetek módszere}

A legkisebb négyzetek módszerét némi módosítással megszabadíthatjuk a fent említett problémáktól. A módosítás a logaritmikus legkisebb négyzetek módszerét (angolul Logarithmic Least Squares Method, röviden LLSM) eredményezi, mely a mátrixelemek logaritmusát a súlyvektor elemek hányadosának logaritmusával hasonlítja össze [23, 27, 28, 66]. Formálisan tehát a logaritmikus legkisebb négyzetek módszere azt a $\mathbf{w}=\left(w_{1}, w_{2}, \ldots, w_{n}\right)^{\top}$ vektort eredményezi súlyvektorként, amely a következô optimalizálási feladat megoldása:

$$
\begin{gathered}
\min \sum_{i=1}^{n} \sum_{j=1}^{n}\left(\log a_{i j}-\log \frac{w_{i}}{w_{j}}\right)^{2} \\
\sum_{i=1}^{n} w_{i}=1 \\
w_{i}>0, \quad i=1, \ldots, n .
\end{gathered}
$$


A legkisebb négyzetek módszerével ellentétben a logaritmikus legkisebb négyzetek módszerének mindig egyértelmú optimuma van: a (2.10) feladatnak a megoldása az a vektor, amelynek elemei a mátrix sorainak mértani közepei [23], azaz

$$
w_{i}=\sqrt[n]{\prod_{j=1}^{n} a_{i j}}, \quad i=1, \ldots, n,
$$

alkalmas normalizálással. Bármely páros összehasonlítás mátrix elemenkénti logaritmusa egy ferdén szimmetrikus mátrix, azaz a transzponáltjának a -1szerese.

A logaritmikus legkisebb négyzetek módszerének számos jó tulajdonsága van, amellyel a sajátvektor módszer nem rendelkezik. Ezek közül kettô a definícióból látható. Az egyik az invariancia a transzponálásra. Ez azt jelenti, hogy az $\mathbf{A}^{\top}$ mátrixhoz tartozó LLSM súlyvektor (normalizálás elôtt) éppen az A mátrixhoz tartozó súlyvektor reciprokaiból áll. Ez annak felel meg, hogy ha a döntéshozó mindenról éppen az ellenkezójét gondolja, mint elótte, akkor az eredmény is éppen az ellenkezője lesz. Egy másik lehetséges értelmezés, hogy inverz skálát használva mérjük az értékeléseket vagy a fontosságokat. Például egy jármú fogyasztását mérhetjük azzal, hogy adott üzemanyaggal mekkora távolságot képes megtenni, vagy akár úgy is, hogy adott távolságot mennyi üzemanyag felhasználásával tud megtenni [38].

A másik, könnyen látható jó tulajdonság a hatvány invariancia, azaz ha a mátrix minden elemét az $r$-edik hatványra emeljük, akkor a belóle számolt súlyvektor is az eredeti súlyvektor elemenkénti $r$-edik hatványa lesz, melyet még normalizálni kell [38, Axiom 4]. Ez a tulajdonság tulajdonképpen tartalmazza az elôző tulajdonságot is. A transzponálásra való invariancia éppen ugyanaz, mint a hatvány invariancia $r=-1$ esetben, mivel a transzponálás páros összehasonlítás mátrixok esetén ugyanaz, mintha elemenkénti reciprokot vennénk.

Ez a tulajdonság több értelmezéssel is bír. Egyrészt értelmezhető úgy, hogy áttérünk egy másik mérési skálára. Egy másik értelmezés, hogy a ver- 
bális fontossági skálákat mindegy, hogyan állítjuk be. Vegyük például a szokásos, Saaty-féle

$$
\{1 / 9, \ldots, 1 / 4,1 / 3,1 / 2,1,2,3,4, \ldots, 9\}
$$

arányskálát [70], amely a 3-as arányhoz a „mérsékelten fontosabb” (moderately more important), az 5-ös arányhoz az „erôsen fontosabb” (strongly more important), stb. verbális fontosságokat társítja (mely verbális megfelelők számos kritika forrásai), a köztes értékeket pedig finomításra használja. Ehelyett használhatnánk például az

$$
\{1 / 81, \ldots, 1 / 16,1 / 9,1 / 4,1,4,9,16, \ldots, 81\}
$$

skálát is, ugyanezeket a verbális fontosságokat rendre a 9-hez, a 25-höz, stb. társítani, ha az LLSM módszert alkalmazzuk. Így a súlyvektor koordinátái helyett azok négyzetei fognak szerepelni.

Egy lényeges összefüggés, hogy $n=3$ esetén a sajátvektor módszer és a logaritmikus legkisebb négyzetek módszere ekvivalens [23]. Így $3 \times 3$-as mátrixok körében bármelyik módszert is használjuk, nemcsak, hogy ugyanazt az eredményt kapjuk, hanem mindkét módszer jó tulajdonságai egyszerre teljesülnek.

\subsubsection{További súlyvektor számítási módszerek}

Az irodalomban igen sok más súlyvektor számítási módszer is megjelent. A különböző módszerek összefoglalását és összehasonlítását ld. pl. a [8, 18] cikkekben. A módszerek a megközelítési módok szerint csoportokba sorolhatóak, melyek közül a legjelentősebb a távolságminimalizáló módszerek csoportja.

\section{Távolságminimalizáló módszerek}

A távolságminimalizáló módszerek népes csoportja intuitív megközelítési módjának köszönheti népszerúségét. A távolságminimalizálás alapötlete az, hogy 
az $\mathbf{A} \in \mathcal{P C} \mathcal{M}_{n}$ mátrixot egy konzisztens mátrixszal közelítsünk a lehetô legjobban, valamilyen célfüggvény szerint [18]. $\mathbf{A} \mathbf{w}=\left(w_{1}, w_{2}, \ldots, w_{n}\right)^{\top}$ súlyvektort, illetve az elemeinek arányaiból alkotható $\mathbf{W}=\left[\frac{w_{i}}{w_{j}}\right]_{i, j=1, \ldots, n} \in \mathcal{P C} \mathcal{M}_{n}^{*}$ konzisztens mátrixot keressük. Keresendô tehát az a w $>0$ súlyvektor, amely megoldása az alábbi optimalizálási feladatnak:

$$
\begin{gathered}
\min d(\mathbf{A}, \mathbf{W}), \\
\text { ahol } \mathbf{W}=\left[\frac{w_{i}}{w_{j}}\right]_{i, j=1, \ldots, n},
\end{gathered}
$$

ahol $d$ egy metrika, és a $\mathbf{w}$ vektorra valamilyen normalizálást alkalmazunk.

Külön említést érdemel a sajátvektor módszer, amely ránézésre nem távolságminimalizáló módszer. Fichtner [37] azonban megmutatta, hogy létezik olyan metrika, amelyben számolt távolságminimalizálás ekvivalens a sajátvektor módszerrel. Legyen $\mathbf{w}(\mathbf{A})=\left(w_{1}(\mathbf{A}), \ldots, w_{1}(\mathbf{A})\right)^{\top}$ az $\mathbf{A}$ mátrixhoz tartozó jobboldali domináns sajátvektor, $\lambda_{\max }(\mathbf{A})$ a hozzá tartozó sajátérték, $d$ pedig a következő:

$$
\begin{aligned}
d(\mathbf{A}, \mathbf{B})= & \sqrt{\sum_{i=1}^{n}\left(w_{i}(\mathbf{A})-w_{i}(\mathbf{B})\right)^{2}}+\frac{1}{2 n-1}\left|\lambda_{\max }(\mathbf{A})-\lambda_{\max }(\mathbf{B})\right|+ \\
& +\frac{1}{2 n-1}\left|\lambda_{\max }(\mathbf{A})-\lambda_{\max }(\mathbf{B})-2 n\right| \chi_{\mathbf{A} \neq \mathbf{B}},
\end{aligned}
$$

ahol

$$
\chi_{\mathbf{A} \neq \mathbf{B}}=\left\{\begin{array}{ll}
0 & \text { ha } \mathbf{A}=\mathbf{B} \\
1 & \text { ha } \mathbf{A} \neq \mathbf{B}
\end{array} .\right.
$$

A fenti furcsa metrika azonban egyrészt nem intuitív, másrészt nem folytonos, így a sajátvektor módszert nem szokták a tipikus távolságminimalizáló módszerek közé sorolni.

Az alfejezet további részében Choo és Wedley [18] tárgyalását követjük, akik számos távolságminimalizáló módszert vizsgáltak és hasonlítottak össze. 
A két legfontosabb távolságminimalizáló módszer a 2.3.2. alfejezetben tárgyalt legkisebb négyzetek módszere (ahol $d$ éppen a Frobenius-norma), valamint annak relaxált változata, a 2.3.3. alfejezetben tárgyalt, még elterjedtebb logaritmikus legkisebb négyzetek módszere.

Hasonló ötleten alapszik a legkisebb legrosszabb négyzet módszere (angolul Least Worst Square, röviden LWS), mely a $\max _{i \neq j}\left(a_{i j}-\frac{w_{i}}{w_{j}}\right)^{2}$ kifejezést, tehát a legnagyobb eltérést minimalizálja. Egy másik módszer az abszolút eltérések összegét, azaz a $\sum_{i} \sum_{j}\left|a_{i j}-w_{i} / w_{j}\right|$ kifejezést minimalizálja, ekkor a legkisebb abszolút hiba módszeréhez (Least Absolute Error, LAE) jutunk.

Abból kiindulva, hogy ha $w_{i} / w_{j}$ közel van $a_{i j}$-hez, akkor a különbségük közel van nullához, azaz $w_{j}$-vel felszorozva az $a_{i j} w_{j}-w_{i}$ kifejezés is közel van nullához, bármely fenti távolságminimalizáló módszer súlyozott változatát is felírhatjuk. Így például a súlyozott legkisebb négyzetek módszerét (Weighted Least Squares, WLS) [20], vagy a súlyozott legkisebb legrosszabb négyzet módszerét (Weighted Least Worst Square, WLWS) kapjuk, melyek rendre a $\sum_{i} \sum_{j}\left(a_{i j} w_{j}-w_{i}\right)^{2}$ és a $\max _{i \neq j}\left(a_{i j} w_{j}-w_{i}\right)^{2}$ kifejezéseket minimalizálják.

Egy másik általános módosítási lehetôség, hogy az $a_{i j}$ és $w_{i} / w_{j}$ értékek helyett azok logaritmusát vesszük, éppen úgy, ahogy a legkisebb négyzetek módszerébôl a logaritmikus legkisebb négyzetek módszerét kaptuk. Így például a logaritmikus legkisebb legrosszabb négyzet módszere (Lo-

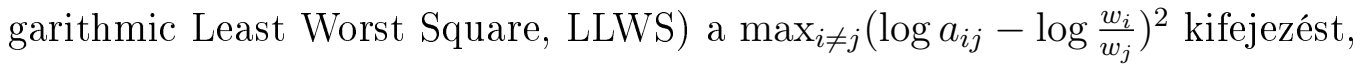
míg a logaritmikus legkisebb abszolút hiba (Logarithmic Least Absolute Error, LLAE)[22] módszere a $\sum_{i} \sum_{j}\left|\log a_{i j}-\log \left(w_{i} / w_{j}\right)\right|$ kifejezést minimalizálja. A súlyozott változatokhoz hasonlóan az összes alapvetô távolságminimalizáló módszer logaritmizált változata is felírható.

A fenti sémákba nem tökéletesen illeszkedô, mégis említést érdemlő távolságminimalizáló módszer a statisztikai ötleten alapuló $\chi^{2}$ módszer [49]. Ez a 
következő kifejezést minimalizálja:

$$
\min \sum_{i=1}^{n} \sum_{j=1}^{n} \frac{\left(a_{i j}-\frac{w_{i}}{w_{j}}\right)^{2}}{\frac{w_{i}}{w_{j}}} .
$$

Egy másik, az eddigiektôl lényegesen különbözô távolságminimalizáló módszer a szinguláris dekompozíció módszere (Singular Value Decomposition, SVD) [40]. Az alapötlet abból a mátrixalgebrában gyakran alkalmazott ténybôl származik, hogy bármely $\mathbf{A} \in \mathbb{R}^{m \times n} k$ rangú mátrix felbontható a következô módon:

$$
\mathbf{A}=\mathbf{U D V}^{\top}
$$

ahol $\mathbf{D}$ egy $k \times k$ méretú diagonális mátrix $\alpha_{1}, \ldots, \alpha_{k}$ diagonális elemekkel, $\mathbf{U}$ egy $m \times k$ méretú, $\mathbf{V}$ pedig egy $n \times k$ méretú mátrix, melyekre $\mathbf{U}^{\top} \mathbf{U}=\mathbf{I}_{k}$ és $\mathbf{V}^{\top} \mathbf{V}=\mathbf{I}_{k}, \mathbf{I}_{k}$ pedig a $k$ dimenziós egységmátrixot jelöli. A (2.12) egyenletet vektor alakba átírva a következôt kapjuk:

$$
\mathbf{A}=\sum_{i=1}^{k} \alpha_{i} \mathbf{u}_{i} \mathbf{v}_{i},
$$

ahol $\mathbf{u}_{i}$ és $\mathbf{v}_{i}$ az $\mathbf{U}$ illetve $\mathbf{V}$ mátrix $i$-edik oszlopa. Az $\alpha_{i}$ értékeket szinguláris értékeknek, az $\mathbf{u}_{i}$ és $\mathbf{v}_{i}$ vektorokat pedig rendre a bal és jobboldali szinguláris vektoroknak nevezzük. Ha az $\alpha_{i}$ értékek közül néhány kicsi a többihez képest, akkor az ezekhez tartozó tagokat elhagyva a (2.13)-beli szummából az A egy kisebb rangú közelítését kapjuk.

Mivel egy konzisztens páros összehasonlítás mátrix 1 rangú és normalizálás erejéig egyértelmú a súlyvektora, valamint fordítva, egy tetszóleges súlyvektorból felírható $a_{i j}=w_{i} / w_{j}$ alakban egy konzisztens páros összehasonlítás mátrix, ezért mondhatjuk, hogy az 1 rangú közelítést keressük. Ez esetben tehát a legnagyobb szinguláris értékhez tartozó közelítést kell vennünk. Ez azonban nem lesz páros összehasonlítás mátrix, így még egy (információelméleti ötleten alapuló célfüggvénnyel ellátott) minimalizálást kell 
végrehajtani:

$$
\begin{gathered}
\min \sum_{i=1}^{n} u_{i} \log \frac{u_{i}}{w_{i}}+\sum_{i=1}^{n} \frac{1}{v_{i}} \log \frac{1}{v_{i} w_{i}} \\
\sum_{i=1}^{n} w_{i}=1 \\
w_{i}>0, \quad i=1, \ldots, n,
\end{gathered}
$$

ahol $\mathbf{u}=\left(u_{1}, \ldots, u_{n}\right)$ és $\mathbf{v}=\left(v_{1}, \ldots, v_{n}\right)$ rendre a legnagyobb szinguláris értékhez tartozó bal és jobb oldali szinguláris vektorok. Ennek a minimalizálási feladatnak az egyértelmú megoldása, mely így egyben a szinguláris dekompozíció módszerének súlyvektora is, a következő:

$$
w_{i}=\frac{u_{i}+\frac{1}{v_{i}}}{\sum_{j=1}^{n}\left(u_{j}+\frac{1}{v_{j}}\right)}, \quad i=1, \ldots, n .
$$

Érdemes megjegyezni, hogy konzisztens mátrixok esetén ez a módszer is ugyanazt adja, mint a sajátvektor módszer, illetve bármelyik másik súlyvektor számítási módszer.

\section{Geometriai megközelítés}

A geometriai megközelítésú módszerek valamilyen szemléletes, mértani hátterú megfontolást alkalmaznak. Az egyik ilyen módszer a Cosinus Maximalizáló módszer [55]. A módszer azon az ötleten alapszik, hogy egy konzisztens páros összehasonlítás mátrix esetén a mátrix rangja 1, és minden oszlop a súlyvektor konstansszorosa: a $j$. oszlop $\left(w_{1} / w_{j}, w_{2} / w_{j}, \ldots, w_{n} / w_{j}\right)^{\top}$ $=\mathbf{w} / w_{j}$. A megfelelő súlyvektor tehát egyirányú (csak legfeljebb konstans szorzóban különböző) bármelyik oszloppal, azaz a bezárt szögük 0. Következésképp a két vektor által bezárt szög cosinusa 1.

Az előző ötletbôl két vektor cosinus hasonlósági mutatóját (cosinus similarity measure) felírva a cél az, hogy ez az egyes oszlopok és a súlyvektor esetében minél közelebb legyen 1-hez. Ezt egy olyan optimalizálási feladattal próbáljuk elérni, hogy az összegüket maximalizáljuk. Formálisan tehát: 


$$
\max \sum_{j=1}^{n} \frac{\sum_{i=1}^{n} w_{i} a_{i j}}{\sqrt{\sum_{i=1}^{n} w_{i}^{2}} \sqrt{\sum_{i=1}^{n} a_{i j}^{2}}}
$$

melyet még ellátunk egy normalizálással. Az optimális megoldás mindig egyértelmú és zárt alakban megadható.

\section{Feszítőfákon alapuló megközelítés}

Az alapötlet ebben az esetben az, hogy egy páros összehasonlítás mátrix megfeleltethető egy gráfnak. Ez úgy történik, hogy minden szempont megfelel egy csúcsnak, így a gráfnak $n$ csúcsa lesz. Továbbá minden összehasonlítás megfelel egy-egy élnek, azaz az $a_{i j}$ mátrixelem megfelel az $i-j$ élnek. Mivel egy teljesen kitöltött páros összehasonlítás mátrixban minden pár közvetlenül össze van hasonlítva, ezért bármely két csúcs között vezet él (késóbb lesz szó nem teljesen kitöltött páros összehasonlítás mátrixokról is, amelyek esetén ez már nem igaz). Így a mátrixhoz tartozó gráf az $n$ pontú teljes gráf, $K_{n}$ lesz.

Legyen $S$ a lehetséges feszítőfák halmaza. Mivel a mátrixhoz tartozó gráf $K_{n}$, ezért $|S|=n^{n-2}$. A páros összehasonlítás mátrixhoz tartozó gráf egy feszítőfája mentén tekintve az összehasonlításokat, ezek egy $s \in S$ egyértelmú súlyvektort határoznak meg a következő módon. Tekintsük azokat az $a_{i j}$ elemeket, amik az $s$ feszítőfa mentén helyezkednek el, azaz amelyekre $(i, j) \in$ $E(s)$. Ekkor minden olyan $a_{k l}$ elemre, amelyre $(k, l) \notin E(s)$, az $s$ feszítófa tulajdonsága miatt a $(k, l)$ él behúzása egy egyértelmú kört hoz létre $s$-ben, legyen ez a $\left(k, i_{1}, i_{2}, \ldots, i_{p}, l\right)$. Mivel az

$$
\left\{a_{i j}=\frac{w_{i}}{w_{j}} \mid(i, j) \in E(s)\right\}
$$

egyenletrendszer normalizálástól eltekintve egyértelmúen oldható meg, az $a_{k l}$ értéket ezen kör mentén konzisztensen meg lehet határozni:

$$
a_{k l}:=a_{k i_{1}} a_{k i_{2}} \ldots a_{i_{p} l}=\frac{w_{k}}{w_{i_{1}}} \frac{w_{i_{1}}}{w_{i_{2}}} \ldots \frac{w_{i_{p}}}{w_{l}} .
$$


Ha ezt az egyértelmú súlyvektort mind az $n^{n-2}$ feszítőfára meghatározzuk, akkor ezek valamilyen aggregálásával határozhatjuk meg az eredeti páros összehasonlítás mátrixhoz tartozó súlyvektort. A két legtermészetesebb aggregálási módszer a vektorok elemenkénti számtani [82, 83], illetve mértani közepe [10]. A mértani középről azonban belátható, hogy ekvivalens a logaritmikus legkisebb négyzetek módszerével [61].

\section{Heurisztikus Súlybecslés}

Ebben az alfejezetben egy olyan módszerrôl lesz szó, amelyrôl magyar nyelven még nem jelent meg leírás, így az elôzố módszerekhez képest kicsit részletesebben tárgyaljuk.

A Heurisztikus Súlybecslés (angolul Heuristic Rating Estimation, röviden HRE) [56] egy, az eddigiektôl teljesen különbözô megközelítésen alapszik. A kiindulás ebben az esetben egy már meglévố súlyvektor. Van tehát néhány alternatívánk, amelyek súlyai már ismertek, és a súlyvektorukban lévő értékek arányaiból egy konzisztens páros összehasonlítás mátrixot alkothatunk. A módszer akkor lép életbe, ha új összehasonlítandó elemek (alternatívák vagy szempontok) jelennek meg.

A HRE módszer úgy számolja az új elemek súlyát, hogy közben a régieké változatlan maradjon (normalizálás erejéig). Legyen $C$ az összes elem halmaza, $C_{K}$ az ismert súlyú elemek halmaza, $C_{U}$ pedig az új, ismeretlen súlyú elemek halmaza. Ekkor $C_{K} \cup C_{U}=C$. Jelölje $n=|C|$ az összes elem számát, $r=\left|C_{U}\right|$ és $k=\left|C_{K}\right|$ pedig rendre az ismeretlen, illetve az ismert elemek számát $(k+r=n)$. Az egyszerúség kedvéért tegyük fel, hogy az ismert elemek vannak ellátva az elsô $k$ indexszel. Ekkor az alábbi mátrixot kapjuk: 


$$
\left(\begin{array}{cccc|ccc}
1 & a_{12} & \ldots & a_{1 k} & m_{1, k+1} & \ldots & m_{1 n} \\
1 / a_{12} & 1 & \ldots & a_{2 k} & m_{2, k+1} & \ldots & m_{2 n} \\
\vdots & \vdots & \ddots & \vdots & \vdots & \ldots & \vdots \\
1 / a_{1 k} & 1 / a_{2 k} & \ldots & 1 & m_{k, k+1} & \ldots & m_{k n} \\
\hline 1 / m_{1, k+1} & 1 / m_{2, k+1} & \ldots & 1 / m_{k, k+1} & 1 & \ldots & m_{k+1, n} \\
\vdots & \vdots & \ldots & \vdots & \vdots & \ddots & \vdots \\
1 / m_{1 n} & 1 / m_{2 n} & \ldots & 1 / m_{k n} & 1 / m_{k+1, n} & \ldots & 1
\end{array}\right)
$$

ahol az $a_{i j}, i, j=1, \ldots, k$ értékek az ismert elemek már meglévố páros összehasonlításai, az $m_{i j}, i, j=k+1, \ldots, n$ pedig az új páros összehasonlítások. Ha az ismert elemek eredeti, megtartandó súlyait $w_{i}, i=1, \ldots, k$-val jelöljük, akkor a bal felsô $k \times k$-as konzisztens részmátrixra $a_{i j}=w_{i} / w_{j}$.

Szeretnénk a már rendelkezésre álló $w_{i}, i=1, \ldots, k$ mellett a még ismeretlen $w_{i}, i=k+1, \ldots, n$ súlyokat is meghatározni. Mivel $a_{i j}=w_{i} / w_{j}$, és $m_{i j} \approx w_{i} / w_{j}$, ezért $w_{i}=a_{i j} w_{j}$ és $w_{i} \approx m_{i j} w_{j}$. Így minden $w_{i}$-re ezeket a kifejezéseket átlagolva egy becslést kapunk a súlyokra. Formálisan minden $C_{U}$-beli ismeretlen elemre a súlyt a következô módon határozzuk meg:

$$
w_{i}=\frac{1}{n-1} \sum_{\substack{j=1 \\ j \neq i}}^{n} m_{i j} w_{j},
$$

ahol $i=k+1, \ldots, n$. Ebben a kifejezésben $i=k+1, \ldots, n$-re a $w_{i}$ értékek ismeretlenek, míg $i=1, \ldots, k$-ra ismertek. Ez egy lineáris egyenletrendszer $r=n-k$ ismeretlennel és ugyanennyi egyenlettel. Ha az ismeretlen tagokat az egyik, az ismert tagokat a másik oldalra rendezzük, akkor az

$$
\mathrm{Mw}^{\prime}=\mathbf{b}
$$

egyenletrendszert kell megoldanunk, ahol $\mathbf{w}^{\prime}=\left(w_{k+1}, \ldots, w_{n}\right)^{\top}$. Továbbá $\mathbf{b}=\left(b_{k+1}, \ldots, b_{n}\right)$, ahol

$$
b_{i}=\frac{1}{n-1} \sum_{j=1}^{k} m_{i j} w_{j},
$$


végül

$$
\mathbf{M}=\left(\begin{array}{cccc}
1 & -\frac{1}{n-1} m_{k+1, k+2} & \ldots & -\frac{1}{n-1} m_{k+1, n} \\
-\frac{1}{n-1} m_{k+2, k+1} & 1 & \ldots & -\frac{1}{n-1} m_{k+2, n} \\
\vdots & \vdots & \ddots & \vdots \\
-\frac{1}{n-1} m_{n, k+1} & -\frac{1}{n-1} m_{n, k+2} & \cdots & 1
\end{array}\right)_{(n-k) \times(n-k)}
$$

Az eredményül kapott $\left(w_{1}, \ldots, w_{k}, w_{k+1} \ldots, w_{n}\right)^{\top}$ vektort még normalizálni kell.

Egyértelmú megoldás tehát pontosan akkor létezik, ha $\mathbf{M}$ invertálható. Sajnos ez nem minden esetben teljesül. Belátható, hogy mindig létezik $\mathbf{M}^{-1}$, ha az eredeti mátrix $C M$ inkonzisztenciája egy bizonyos érték alatt van [57]. A $C M$ inkonzisztenciát részletesebben ld. a 2.4.2. alfejezetben, de lényegében arról van szó, hogy a kardinális tranzitivitás nem sérülhet túlságosan.

Nézzünk egy példát a Heurisztikus Súlybecslés alkalmazására. Tegyük fel, hogy jelenleg 3 alternatívánk van, például három termék van jelen a piacon. Jelölje ezeket $A_{1}, A_{2}$ és $A_{3}$. Továbbá tegyük fel, hogy ezen termékek (egy szempont szerinti) értékelései, például a piaci részesedésük rendre 6,3 és 1 . Ekkor a jelenlegi súlyvektor $(6,3,1)^{\top}$, avagy normalizálva $(0,6 ; 0,3 ; 0,1)^{\top}$. Ez a példánkban azt jelenti, hogy a három piacon lévő termék részesedése 60\%, 30\%, és 10\%. Az ezekból alkotható konzisztens páros összehasonlítás mátrixot jelölje $\mathbf{A}_{0}$ :

$$
\mathbf{A}_{0}=\left(\begin{array}{ccc}
1 & 2 & 6 \\
1 / 2 & 1 & 3 \\
1 / 6 & 1 / 3 & 1
\end{array}\right)
$$

Tegyük fel, hogy két új terméket is piacra szeretnénk dobni, ami annak felel meg, hogy két új alternatíva, $A_{4}$ és $A_{5}$ kerül be a rendszerbe. Feltesszük, hogy az új termékek nem befolyásolják a régiek iránti kereslet egymáshoz viszonyított arányait. Ez azt jelenti, hogy szeretnénk az új alternatívák súlyait (avagy értékeléseit, jelen esetben piaci részesedéseit) meghatározni úgy, hogy a régieké normalizálás erejéig változatlan marad. Az új alternatívák piaci részesedéseit a szokásos módon páronként hasonlítjuk össze a régiekkel, illetve 
egymással. A feltett kérdés például lehet az, hogy „hányszor több bevételt tudunk elérni az $A_{i}$ termékbőll, mint az $A_{j}$-ből??". Az új összehasonlítások szerint $A_{1} 4$-szer jobb $A_{4}$-nél, és 3 -szor $A_{5}$-nél, stb. Az új értékelésekkel kiegészített mátrixot jelölje $\mathbf{A}$, és legyen a következő:

$$
\mathbf{A}=\left(\begin{array}{ccc|cc}
1 & 2 & 6 & 4 & 3 \\
1 / 2 & 1 & 3 & 3 & 2 \\
1 / 6 & 1 / 3 & 1 & 2 & 1 \\
\hline 1 / 4 & 1 / 3 & 1 / 2 & 1 & 2 \\
1 / 3 & 1 / 2 & 1 & 1 / 2 & 1
\end{array}\right)
$$

Az ismeretlen új súlyokat $\left(\mathbf{w}^{\prime}=\left(w_{4}, w_{5}\right)\right)$ a többi súlyból az egyes páros összehasonlításokból visszaszámolható értékek átlagaként szeretnénk meghatározni a (2.15) képlettel. A régi súlyok tehát $w_{1}=6, w_{2}=3, w_{3}=1$. Ekkor

$$
\begin{aligned}
& w_{4}=\frac{1}{4}\left(\frac{1}{4} \cdot 6+\frac{1}{3} \cdot 3+\frac{1}{2} \cdot 1+2 \cdot w_{5}\right), \\
& w_{5}=\frac{1}{4}\left(\frac{1}{3} \cdot 6+\frac{1}{2} \cdot 3+1 \cdot 1+\frac{1}{2} \cdot w_{4}\right) .
\end{aligned}
$$

A zárójeleket felbontva a következőket kapjuk:

$$
\begin{aligned}
& w_{4}=\frac{3}{4}+\frac{1}{2} \cdot w_{5}, \\
& w_{5}=\frac{9}{8}+\frac{1}{8} \cdot w_{4} .
\end{aligned}
$$

Ezt a feladat mérete miatt könnyedén megoldhatnánk egyszerú visszahelyettesítéssel is, de a módszer szemléltetése végett nézzük meg, mi lesz a (2.15)(2.16) formulákban szereplô $\mathbf{M}$ és $\mathbf{b}$.

$$
\begin{gathered}
\mathbf{b}=\left(\begin{array}{c}
\frac{3}{4} \\
\frac{9}{8}
\end{array}\right), \\
\mathbf{M}=\left(\begin{array}{cc}
1 & -\frac{1}{2} \\
-\frac{1}{8} & 1
\end{array}\right) .
\end{gathered}
$$


Azaz a megoldandó (2.16) egyenletrendszer:

$$
\left(\begin{array}{cc}
1 & -\frac{1}{2} \\
-\frac{1}{8} & 1
\end{array}\right)\left(\begin{array}{l}
w_{4} \\
w_{5}
\end{array}\right)=\left(\begin{array}{c}
\frac{3}{4} \\
\frac{9}{8}
\end{array}\right)
$$

Ennek a megoldása

$$
\mathbf{w}^{\prime}=\left(\begin{array}{c}
w_{4} \\
w_{5}
\end{array}\right)=\mathbf{M}^{-1} \mathbf{b}=\left(\begin{array}{cc}
1 & -\frac{1}{2} \\
-\frac{1}{8} & 1
\end{array}\right)^{-1}\left(\begin{array}{c}
\frac{3}{4} \\
\frac{9}{8}
\end{array}\right)=\left(\begin{array}{cc}
\frac{16}{15} & \frac{8}{15} \\
\frac{2}{15} & \frac{16}{15}
\end{array}\right)\left(\begin{array}{c}
\frac{3}{4} \\
\frac{9}{8}
\end{array}\right)=\left(\begin{array}{c}
\frac{7}{5} \\
\frac{13}{10}
\end{array}\right) .
$$

Így a végsô súlyvektor $(6,3,1,7 / 5,13 / 10)^{\top}$, melyet még normalizálhatunk, azaz a piaci részesedések kerekítve rendre 47,2\%, 23,6\%, 7, 9\%, $11 \%$ és 10,2\%. Vegyük észre azonban, hogy a normalizálástól független eredményt kapunk, ugyanis ha a régi súlyokat beszorozzuk egy $c$ konstanssal, akkor az azzal ekvivalens, hogy b helyett $c \mathbf{b}$ fog szerepelni a (2.16) egyenletben, ahonnan

$$
\mathbf{w}^{\prime}=c \mathbf{M}^{-1} \mathbf{b},
$$

azaz az új súlyok is $c$-vel szorzódnak.

A HRE módszert használhatjuk például ingatlanok értékbecslése esetén is: van már néhány hasonló kategóriájú ingatlan a piacon, és a most újonnan eladásra kínált ingatlanok árát szeretnénk megbecsülni, természetesen a régiekét változatlanul hagyva. Azért a hasonló kategóriával érdemes összehasonlítani, mert ilyen esetekben a többször akkora értéket képviselő ingatlanok piaca már másképp múködhet. Következésképp a páros összehasonlítás mátrix 1-hez közeli értékekkel lesz feltöltve, és az új ingatlanok becsült árai is viszonylag közel lesznek a régiekéhez.

\subsection{Inkonzisztencia indexek}

A 3. Definíció szerint egy páros összehasonlítás mátrix inkonzisztens, ha nem konzisztens, azaz nem teljesül rá a 2. Definícióbeli (2.3) kardinális tranzitivitás. Azonban már ránézésre is vannak „kevésbé” és „erősen” inkonzisztens 
mátrixok. Tekintsük például a következő két páros összehasonlítás mátrixot:

$\mathbf{A}=\left(\begin{array}{ccc}1 & 2 & 4,1 \\ 1 / 2 & 1 & 2 \\ 1 / 4,1 & 1 / 2 & 1\end{array}\right), \quad \mathbf{B}=\left(\begin{array}{ccc}1 & 2 & 9 \\ 1 / 2 & 1 & 2 \\ 1 / 9 & 1 / 2 & 1\end{array}\right), \quad \mathbf{C}=\left(\begin{array}{ccc}1 & 2 & 1 / 8 \\ 1 / 2 & 1 & 2 \\ 8 & 1 / 2 & 1\end{array}\right)$

Mind az A, mind a $\mathbf{B}$ mátrixot egy tetszőleges főátlón kívüli elem és reciprokának megváltoztatásával konzisztenssé lehet tenni. Azonban ha belegondolunk, hogy ha a jobb fölsố sarokba 4-et írunk, akkor ugyanazt a konzisztens mátrixot kapjuk mindkét esetben, akkor látható, hogy a $\mathbf{B}$ mátrix „,inkonzisztensebb”, vagy „távolabb van a konzisztenstől”, mint az A mátrix. Még a $\mathbf{B}$ mátrixnál is „,kevésbé konzisztensnek” tûnik a $\mathbf{C}$ mátrix, amely nem csak kardinálisan, hanem ordinálisan is ellentmondásos. Ezt a koncepciót ragadják meg az inkonzisztencia indexek, melyeket inkonzisztencia mérôszámoknak is hívnak, és az inkonzisztencia mértékét hivatottak számszerúsíteni.

Az inkonzisztencia mérôszámok egy jelentôs része egy-egy súlyvektor számítási módszerhez kötődik szorosan. Az irodalomban sok inkonzisztencia indexet bevezettek már [14, 15], ezért a következőekben csak a legfontosabbak bemutatására kerül sor.

Az inkonzisztencia témakörének részletes tárgyalása megtalálható Poesz Attila disszertációjában, mely a Budapesti Corvinus Egyetem Általános és Kvantitatív Közgazdaságtan Doktori Iskolájában született [64].

\subsubsection{A $C R$ index}

A Saaty [69] által bevezetett $C R$ (Consistency Ratio) index egyidôs az AHP módszerrel, és a sajátvektor módszerrel (ld. a 2.3.1. alfejezetben) van szoros kapcsolatban.

Mivel egy páros összehasonlítás mátrix legnagyobb sajátértékére $\lambda_{\max } \geq n$ és ez a reláció pontosan akkor teljesül egyenlőséggel, ha a mátrix konzisztens, ezért a $\lambda_{\max }$ értéke felhasználható egy inkonzisztencia index képzésére. $\lambda_{\max }$ lehetséges nagysága azonban a mátrix dimenziójától (azaz a szempontok 


\begin{tabular}{|c|c|c|c|c|c|c|c|c|}
\hline$n$ & 3 & 4 & 5 & 6 & 7 & 8 & 9 & 10 \\
\hline$R I$ & 0,58 & 0,90 & 1,12 & 1,24 & 1,32 & 1,41 & 1,45 & 1,49 \\
\hline
\end{tabular}

2.1. táblázat. Az RI értékei

számától), vagyis $n$-tôl függ, ezért ezt elôszzör egyfajta normalizálásnak kell alávetni. Innen ered az elsố kiszámítandó érték, a CI (Consistency Index), melyet a következő módon kapunk:

$$
C I=\frac{\lambda_{\max }-n}{n-1} .
$$

A $C I$ index azonban még mindig nem alkalmas különböző méretû mátrixok összehasonlítására, mert nagyobb (véletlengenerált) mátrixok átlagos $C I$ értéke nagyobb, mint a kisebbeké. Így még ezt a mutatót is tovább kell normálni, hogy megkapjuk a $C R$ indexet. A további normáláshoz véletlengenerált $n \times n$-es páros összehasonlítás mátrixok sokaságára kell kiszámítani a $C I$ mutatót, és ezek átlagát nevezzük $R I$-nek (Random Index), mely $n$-tól függ, azaz

$$
R I=\frac{\overline{\lambda_{\max }}-n}{n-1},
$$

ahol $\overline{\lambda_{\max }}$ az $n \times n$-es véletlengenerált páros összehasonlítás mátrixok átlagos $\lambda_{\max }$ értéke. Ilyen módon az $R I$ egy-egy valós szám lesz minden $n$-re, mely kigyúj thetô egy táblázatba (ld. például [89, Table 1], vagy a 2.1. táblázatban).

A véletlen mátrixok generálása úgy történik, hogy a páros összehasonlítás mátrix felsố háromszögének minden elemét véletlenszerủen választjuk egyenletes eloszlás szerint az

$$
\{1 / 9, \ldots, 1 / 4,1 / 3,1 / 2,1,2,3,4, \ldots, 9\}
$$

halmazból, az alsó háromszög elemeit pedig ezek reciprokaival töltjük ki. A véletlen mátrixokra kiszámított $C I$ értékek átlaga lesz az $R I$. Ennek segítségével már előállítható a $C R$ mutató:

$$
C R=\frac{C I}{R I}
$$


Figyeljük meg, hogy konzisztens mátrix esetén $\lambda_{\max }=n$ miatt $C I=0$, következésképp $C R=0$. Fordítva is igaz, hogy ha a mátrix nem konzisztens, akkor $\lambda_{\max }>n$ miatt $C I>0$, emiatt pedig $C R>0$.

Saaty eredeti javaslata alapján ha $C R(\mathbf{A})<0,1$, akkor a mátrixot elfogadható inkonzisztenciájúnak tekintjük. A $C R$ mutatót százalékban is szokás kifejezni, ekkor azt mondhatjuk, hogy akkor fogadjuk el megfelelően kicsi inkonzisztenciájúnak a mátrixot, ha a $C R$ értéke 10\% alatt van. Egy későbbi könyvében Saaty már 5\%-os küszöböt javasol $3 \times 3$-as, és 8\%-os küszöböt $4 \times 4$-es mátrixok esetén, nagyobb mátrixokra pedig a $10 \%$ megtartását $[72$, Chapter 3.4].

A $C R$ index előnyeként tartható számon ez a küszöbérték, mellyel sok más inkonzisztencia nem rendelkezik. Azonban problémaként szokták felhozni a küszöb értékének önkényességét. Egy másik önkényes dolog a véletlen mátrixok generálásának ténye, illetve módja. Egyrészt nem mindenki ugyanabból a halmazból választja a véletlen értékeket, ezért a táblázatban szereplő értékek is eltérhetnek [84]. Másrészt a véletlengenerált mátrixok között olyan a valóságtól elrugaszkodott mátrixok is szerepelnek, ami például nagyon erôs körbeveréseket tartalmaz. Harmadrészt a Saaty-féle 1-9 skála és a hozzárendelt verbális kategóriák jogosságát is lehet vitatni: a „kicsit jobb" valóban 3-szor jobbat jelentene? Saaty ennek orvoslására azt javasolja, hogy ha az összehasonlítandó elemek közel vannak egymáshoz, akkor a szokásos skála helyett az 1,1.1,1.2, ., 1.9 számokat és reciprokaikat használjuk [71]. Egy másik elterjedt skála az úgynevezett kiegyensúlyozott skála [65], ami 1-9-ig használ értékeket, de a kisebb értékek felé jóval sưrúbb. A $C R$ indexhez használt véletlengenerált mátrixokat azonban Saaty eredeti 1-9 skálája alapján határozzák meg. Mindazonáltal a $C R$ index és küszöbértéke széles körben elfogadott és alkalmazott, ami mindenképpen fontos tényezó, továbbá az inkonzisztencia indexek közül ez a legismertebb és valószínúleg a legnépszerúbb. 


\subsubsection{A $C M$ index}

A Koczkodaj [52] által bevezetett $C M$ (Consistency Measure) index szintén nagy népszerûségnek örvend, köszönhetôen annak, hogy igen látványos ötleten alapszik. Tekintsünk egy általános $3 \times 3$-as páros összehasonlítás mátrixot, azaz triádot:

$$
\mathbf{T}=\left(\begin{array}{ccc}
1 & a & b \\
1 / a & 1 & c \\
1 / b & 1 / c & 1
\end{array}\right)
$$

A késóbbiekben a fenti $\mathbf{T}$ triádot $(a, b, c)$-vel is jelöljük, hiszen e három eleme egyértelmúen meghatározza.

A $\mathbf{T}$ mátrix pontosan akkor konzisztens, ha $b=a c$. Ennek a feltételnek három módon is könnyedén eleget tehetünk: két elemet rögzítve a harmadikat úgy változtatjuk meg, hogy $b=a c$ teljesüljön. Ha az $a$ elemet változtatjuk meg, akkor $a=\frac{b}{c}$, ha a $b$ elemet, akkor $b=a c$, ha pedig a $c$ elemet, akkor $c=$ $\frac{b}{a}$. A $C M$ index az így kapott legközelebbi konzisztens mátrixtól való relatív távolságot méri. Formálisan tehát $3 \times 3$-as páros összehasonlítás mátrixok esetén

$$
C M(\mathbf{T})=\min \left\{\frac{1}{a}\left|a-\frac{b}{c}\right|, \frac{1}{b}|b-a c|, \frac{1}{c}\left|c-\frac{b}{a}\right|\right\} .
$$

Ez a képlet egyszerûsíthető a következő, ekvivalens formára [31]:

$$
C M(\mathbf{T})=\min \left\{\left|1-\frac{b}{a c}\right|,\left|1-\frac{a c}{b}\right|\right\} .
$$

Nagyobb mátrixok esetére is kiterjeszthető a definíció. Egy páros összehasonlítás mátrixban az $(i, j, k)$ indexhármashoz tartozó

$$
\left(\begin{array}{ccc}
1 & a_{i j} & a_{i k} \\
1 / a_{i j} & 1 & a_{j k} \\
1 / a_{i k} & 1 / a_{j k} & 1
\end{array}\right)
$$


alakú részmátrixot - mely tehát maga is egy páros összehasonlítás mátrix triádnak nevezünk. Triádokra már ismert a $C M(2.17)$, illetve (2.18) definíciója. Az A mátrix $C M$ indexe az összes triádjai közül a legrosszabb $C M$ érték lesz, azaz

$$
C M(\mathbf{A})=\max \left\{\min \left\{\left|1-\frac{b}{a c}\right|,\left|1-\frac{a c}{b}\right|\right\} \text { az A összes }(a, b, c) \text { triádjára }\right\} .
$$

Bár a $C M$ index interpretálható úgy, hogy egy páros összehasonlítás mátrix relatív távolságát méri a legközelebbi konzisztens mátrixtól, ennek ellenére nem metrika. Az index egyik előnye a könnyű értelmezhetôség. Egy másik nagyon fontos előnye, hogy azt is megmondja, hogy az inkonzisztencia a mátrixon belül hol, melyik triádból fakad, mert csak meg kell néznünk, hogy a (2.19) kifejezés melyik triádnál veszi fel a maximumát. Számítási igény tekintetében polinomiális, mert a lehetséges triádok száma [31]: $\left(\begin{array}{l}n \\ 3\end{array}\right)=n(n-1)(n-2) / 6$.

Hátrányaként említhetô, hogy megkérdőjelezhetô, hogy egy mátrixot tényleg a legrosszabb triádja reprezentálja-e. Más szóval a $C M$ index ugyanolyan értéket ad, ha minden triádja „nagyon rossz”, mint ha csak egy ilyen van köztük, a többi pedig kevésbé inkonzisztens.

A Koczkodaj-féle $C M$ index egy igen szemléletes karakterizációját mutatja be Csató [26]. Hat természetes, alapvetôen a triádokra felírt axiómával karakterizálni lehet a $C M$ indexet. Az első a pozitív fogékonyság, ami azt jelenti, hogy az olyan „elemi” triádok között, amelyek a csupa 1-es triádtól ugyanabban az egy elemben térnek csak el, az 1-hez közelebbi eltérés jobb inkonzisztencia értéket kell adjon. A második a preferenciák inverziójára való invariancia, azaz ha megfordulnak a preferenciák, vagyis az eredeti $\mathbf{T}$ triád helyett a $\mathbf{T}^{\top}$-at tekintjük, akkor $\mathbf{T}$ és $\mathbf{T}^{\top}$ inkonzisztenciája ugyanaz. A harmadik, az elemek homogén kezelése azt mondja, hogy az $\left(1, t_{2}, t_{3}\right)^{1}$

$$
{ }^{1} \mathrm{az}\left(\begin{array}{ccc}
1 & 1 & t_{2} \\
1 & 1 & t_{3} \\
1 / t_{2} & 1 / t_{3} & 1
\end{array}\right) \text { triádnak az alfejezet elején bevezetett rövidebb jelölése }
$$


és az $\left(1, t_{2} / t_{3}, 1\right)$ triádok inkonzisztenciája azonos. A negyedik, a skálainvariancia azt mondja ki, hogy $\left(t_{1}, t_{2}, t_{3}\right)$ és $\left(k t_{1}, k^{2} t_{2}, k t_{3}\right)$ inkonzisztenciája azonos tetszóleges $k>0$-ra. Az ötödik, a monotonitás azt mondja, hogy egy páros összehasonlítás mátrix inkonzisztenciája nem lehet alacsonyabb, mint bármely triádjáé. Végül a legérdekesebb a hatodik axióma, a reducibilitás. A reducibilitás azt mondja, hogy bármely páros összehasonlítás mátrixnak létezik olyan triádja, amellyel megegyezik az inkonzisztenciája. Ez az utolsó axióma azt garantálja, hogy egy mátrix inkonzisztenciája visszavezethetô legyen egy triádjának az inkonzisztenciájára. A fenti axiómák függetlenek [26, Section 5], és általuk a $C M$ index által generált inkonzisztencia rangsort lehet karakterizálni. A $C M$ index monoton transzformációi, melyek ugyanazt a rangsort adják, szintén megfelelnek ezeknek az axiómáknak.

Egy másik axiomatikus megközelítést alkalmaz Koczkodaj és Szwarc [54], valamint ennek továbbfejlesztését Koczkodaj és Magnot [53]. Az [53] cikkben öt axiómát állítanak fel. Az elsô a konzisztencia detektálás, azaz konzisztens mátrixra az inkonzisztencia indexe 0 kell legyen. Ezt az axiómát Csató axiómáihoz is hozzá lehet venni, ám még ezzel sem tudjuk kizárni a $C M$ index összes alkalmas transzformációját [26]. A második axióma a normalizálás, azaz az inkonzisztencia értékének a [0,1] intervallumban kell lennie. A harmadik egy hiba intoleranciának nevezett, inkább technikai leírású axióma, melynek lényege, hogy nagy mátrixok esetén se toleráljuk a nagy relatív hibákat. A negyedik a monotonitás, amit ebben az axiomatizálásban úgy mondanak ki, hogy egy mátrix inkonzisztenciája legalább akkora, mint bármely részmátrixáé. Az ötödik axióma az összehasonlítások sorrendjére való invariancia, ami azt követeli meg, hogy az inkonzisztencia ne függjön az összehasonlítandó elemek sorrendjétől. Érdemes megjegyezni, hogy sem a folytonosságot, sem a transzponálásra való invarianciát nem várják el. 


\subsubsection{A $G C I$ index}

Az Aguarón és Moreno-Jimenez által bevezetett [7] GCI (Geometric Consistency Index) a logaritmikus legkisebb négyzetek módszeréhez (LLSM) kötődik. Az elnevezése is innen jön, mivel az LLSM módszert sor-geometriai közép módszernek (Row Geometric Mean Method) is szokás nevezni. Az alapötlet abból az összefüggésból származik, hogy a súlyvektornak közel kell lennie a mátrix elemeihez, tehát $a_{i j}=w_{i} / w_{j}$. Ezt átrendezve az

$$
a_{i j} \frac{w_{j}}{w_{i}}=1
$$

összefüggést kapjuk. Crawford és Williams javaslatából kiindulva (innen származnak a konstansok) [23] egy páros összehasonlítás mátrix GCI indexe a következó módon írható fel:

$$
G C I(\mathbf{A})=\frac{2}{(n-1)(n-2)} \sum_{i<j} \log ^{2}\left(a_{i j} \frac{w_{j}}{w_{i}}\right),
$$

ahol $\mathbf{w}=\mathbf{w}^{L L S M}$, azaz a logaritmikus legkisebb négyzetek módszeréból számolt súlyvektor. Mivel $\left(\begin{array}{l}n \\ 2\end{array}\right)$ tag szerepel a szummában, ezért a $G C I$ index ezeknek a logaritmikus eltérésnégyzeteknek az átlagaként adódik.

Könnyen látható, hogy ez a logaritmikus legkisebb négyzetek módszerének célfüggvénye egy konstanssal szorozva (rögzített $n$-re), ha a következő formába írjuk át:

$$
G C I(\mathbf{A})=\frac{2}{(n-1)(n-2)} \sum_{i<j}\left(\log a_{i j}-\log \frac{w_{i}}{w_{j}}\right)^{2} .
$$

Érdemes megjegyezni, hogy például a $C M$ indexszel ellentétben itt az inkonzisztencia a súlyvektortól is függ. Tehát ugyanarra a mátrixra különböző $G C I$ értékeket kapunk különböző súlyvektorok esetén. A GCI indexet azonban (2.21)-ból láthatóan éppen a logaritmikus legkisebb négyzetek módszere minimalizálja. Ezért, bár elméletileg bármely súlyvektorra értelmezhetnénk ezt az indexet, a definícióban azt a súlyvektort választjuk, amelyre (2.21) 
minimális értéket ad. Így a definícióban $\mathbf{w}=\mathbf{w}^{L L S M}$, azaz az LLSM súlyvektorral számolunk [7, Definition 1].

A $G C I$ elônye, hogy a $C R$ indexhez hasonlóan elfogadhatósági küszöbértékek is tartoznak hozzá. Pontosabban Aguarón és Moreno-Jimenez úgy határozták meg a küszöböket, hogy éppen a Saaty-féle $C R=0$,1-es küszöbértéknek feleljenek meg. A $G C I$ elfogadhatósági küszöbei így $n=3$-ra $G C I=0,3147, n=4$-re $G C I=0,3526, n>4$-re pedig $G C I=0,37$.

\subsubsection{Távolságminimalizáló módszerek indexei}

Bármely távolságminimalizáló súlyvektor számítási módszer (ld. 2.3.4. alfejezet) célfüggvénye 0 értéket vesz fel konzisztens mátrixok esetén, inkonzisztens mátrixok esetén pedig fel lehet fogni a célfüggvény értékét úgy, mint a legközelebbi konzisztens mátrixtól való távolságot, azaz az inkonzisztencia nagyságát. Így maga a célfüggvény értéke, vagy annak egy monoton transzformációja egy alkalmas inkonzisztencia mérôszám lesz.

A célfüggvényben azonban minden esetben szerepel a keresett $\mathbf{w}$ súlyvektor. Ezt elméletileg bármely súlyvektorral kiszámolhatnánk, ám ekkor ugyanaz a mátrix különböző súlyvektorokkal különböző inkonzisztenciát kapna. A súlyvektortól való függést elkerülendô minden célfüggvényhez azt a súlyvektort vehetnénk, ahol a minimum felvétetik, azaz az optimalizálási feladat megoldását.

Ily módon minden távolságminimalizáló módszer egyben egy inkonzisztencia mérés is, minden célfüggvénybe a feladat által adott súlyvektort helyettesítve. Egy példa a GCI index (ld. elôzô alfejezet), mely szintén felfogható optimalizálási feladatként, melynek minimuma a $\mathbf{w}=\mathbf{w}^{L L S M}$ helyen van, így az ezen a helyen vett célfüggvény érték lesz a GCI index. Ezekhez az inkonzisztencia mérôszámokhoz általában nem tartozik elfogadhatósági küszöb (kivétel éppen a GCI index), és az abszolút nagyságukat is nehéz értelmezni, viszont mátrixok összehasonlítására alkalmasak. A módosítatlan formájukban ezek az indexek csak egyforma méretú mátrixok összehasonlítására jók, 
mert különbözô méretú mátrixok esetén az összegek különböző mennyiségú tagokból állnak, és hiányzik egy dimenzióktól függetlenítô normálás. A probléma azonban könnyen áthidalható, ha leosztunk például a tagok számával, így az eltérô méretû mátrixok is összehasonlíthatóak lesznek.

Idônként nem magát a célfüggvényt, hanem annak egy monoton transzformációját alkalmazzuk az inkonzisztencia mérésére. Az egyik ilyen a logaritmikus legkisebb négyzetek módszere és a $G C I$ index, ahol az átlagolás végett [23] egy konstanssal szorozzuk az LLSM célfüggvényt. Egy másik ilyen példa a legkisebb négyzetek módszere (LSM, ld. 2.3.2. alfejezet), ahol a négyzetes normában való mérés miatt a célfüggvény négyzetgyöke a természetes mérôszám:

$$
\sqrt{\sum_{i=1}^{n} \sum_{j=1}^{n}\left(a_{i j}-\frac{w_{i}^{L S M}}{w_{j}^{L S M}}\right)^{2}} .
$$

Hasonlóan járhatunk el más négyzetes eltérést mérô távolságminimalizáló módszerek esetén, például a súlyozott legkisebb négyzetek módszerénél (WLS) az inkonzisztenciát a következô módon mérhetjük:

$$
\sqrt{\sum_{i=1}^{n} \sum_{j=1}^{n}\left(a_{i j} w_{j}^{W L S}-w_{i}^{W L S}\right)^{2} .}
$$

Ahol abszolút eltérést mérünk, ott a gyökvonás szükségtelen, mert ez esetben a távolság az 1-es normával analóg. Ilyenkor tisztán a célfüggvény értéke a természetes mérốszám. Mivel azonban ezeket az inkonzisztencia mértékeket egyébként is leginkább mátrixok összehasonlítására használhatjuk, ezért a transzformációnak elvi jelentôsége nincs.

Nem minden távolságminimalizáló módszernek van ilyen természetes inkonzisztencia mérószáma. Például a szinguláris dekompozíció (SVD) esetén a két lépcsôs optimalizálás miatt érdemes a legkisebb négyzetek célfüggvényét használni az SVD súlyvektorával, azaz Frobenius-normában mérni a 
távolságot [40], még akkor is, ha általában $w^{L S M} \neq w^{S V D}$ :

$$
\sqrt{\sum_{i=1}^{n} \sum_{j=1}^{n}\left(a_{i j}-\frac{w_{i}^{S V D}}{w_{j}^{S V D}}\right)^{2}}
$$

\subsection{Nem teljesen kitöltött páros összehasonlítás mátrixok}

Előfordul olyan eset, hogy nem áll rendelkezésünkre az összes páros összehasonlítás, csak azok egy részhalmaza. Olyan eset is adódhat, hogy nem akarjuk, vagy nem is áll módunkban mind az $\left(\begin{array}{l}n \\ 2\end{array}\right)$ összehasonlítást végigkérdezni a döntéshozótól. Ilyenkor a páros összehasonlítás mátrix bizonyos elemei lesznek csak kitöltve, a többi hiányzik. Ilyenkor nem teljesen kitöltött páros összehasonlítás mátrixról beszélünk [42]:

4. Definíció. A egy nem teljesen kitöltött páros összehasonlítás mátrix, ha az alábbi alakot ölti:

$$
\mathbf{A}=\left(\begin{array}{ccccc}
1 & a_{12} & - & \ldots & a_{1 n} \\
1 / a_{12} & 1 & a_{23} & \ldots & - \\
- & 1 / a_{23} & 1 & \ldots & a_{3 n} \\
\vdots & \vdots & \vdots & \ddots & \vdots \\
1 / a_{1 n} & - & 1 / a_{3 n} & \ldots & 1
\end{array}\right)
$$

ahol a kihúzott pozíciókban hiányzó elemek vannak, és $a_{i j}>0$. A hiányzó elemek a főátlón kívül bárhol lehetnek, nem csak az itt szemléltetésként felhozott pozíciókban. Továbbá ha egy elem hiányzik, akkor a reciproka is.

A reciprok szimmetriát figyelembe véve minden ismert elemmel átellenes elem is ismert, hiszen beírhatjuk az ismert elem reciprokát. Másképpen fogalmazva $a_{i j}$ pontosan akkor hiányzik, ha $a_{j i}$ hiányzik.

A nem teljesen kitöltött páros összehasonlítás mátrixok a páros összehasonlítás mátrixok általánosításai. Speciálisan ha egy nem teljesen kitöltött 
mátrixban a kitöltetlen elemek halmaza üres, akkor egy „,szokásos” kitöltött páros összehasonlítás mátrixot kapunk (1. Definíció).

A 4. Definícióban szereplő objektum formálisan nem mátrix, ezért ilyen formában nem is lehet ekként kezelni. Matematikailag megfoghatóvá válik azonban, ha a hiányzó elemek helyére változókat írunk. Ekkor is figyelnünk kell a reciprok szimmetriára, azaz ha egy hiányzó helyre beírunk egy változót, akkor az átellenes pozícióba ugyanannak a változónak a reciprokát kell írnunk. Így tehát annyi változónk lesz, ahány elem hiányzik a mátrix felsô háromszögéból. A továbbiakban ezt tekintjük a hiányzó elemek számának.

5. Definíció. $\mathbf{A}\left(x_{1}, \ldots, x_{d}\right)$ az $x_{1}, \ldots, x_{d}$ elemekkel kitöltött páros összehasonlítás mátrix, ha

$$
\mathbf{A}\left(x_{1}, \ldots, x_{d}\right)=\mathbf{A}(\mathbf{x})=\left(\begin{array}{ccccc}
1 & a_{12} & x_{1} & \ldots & a_{1 n} \\
1 / a_{12} & 1 & a_{23} & \ldots & x_{d} \\
1 / x_{1} & 1 / a_{23} & 1 & \ldots & a_{3 n} \\
\vdots & \vdots & \vdots & \ddots & \vdots \\
1 / a_{1 n} & 1 / x_{d} & 1 / a_{3 n} & \ldots & 1
\end{array}\right)
$$

ahol $x_{1}, x_{2}, \ldots, x_{d} \in \mathbb{R}_{+}$és $d$ a hiányzó elemek száma.

A továbbiakban, ha nem okoz zavart, akkor az $\mathbf{A}\left(x_{1}, \ldots, x_{d}\right)$ jelölés helyett egyszerúen az $\mathbf{A}$ jelölést használjuk. Egy másik értelmezés alapján gondolhatunk úgy is egy nem teljesen kitöltött mátrixra, mint az összes lehetséges kitöltése által generált teljesen kitöltött páros összehasonlítás mátrixok halmazára.

Egy egyszerú példa egy nem teljesen kitöltött páros összehasonlítás mátrixra, pontosabban az $x_{1}$ elemmel kitöltött mátrixra a következó:

$$
\mathbf{A}\left(x_{1}\right)=\left(\begin{array}{ccc}
1 & 2 & x_{1} \\
1 / 2 & 1 & 4 \\
1 / x_{1} & 1 / 4 & 1
\end{array}\right)
$$


Ebben az esetben $d=1$, azaz csak egy hiányzó elem van. Az is látszik, hogy ez a mátrix konzisztensen kitölthetô, ha $x_{1}$ helyére 8-at írunk. Ilyen módon természetesen adódik, hogy az $\mathbf{A}\left(x_{1}\right)$ mátrixhoz tartozó súlyvektor legyen a konzisztens kitöltéséhez (jelen esetben $\mathbf{A}(8)$-hoz) tartozó súlyvektor. Sajnos azonban nagyobb mátrixok esetén általában nem lehet konzisztens kitöltést találni. Például:

$$
\mathbf{A}\left(x_{1}, x_{2}\right)=\left(\begin{array}{cccc}
1 & 2 & x_{1} & 9 \\
1 / 2 & 1 & 2 & x_{2} \\
1 / x_{1} & 1 / 2 & 1 & 2 \\
1 / 9 & 1 / x_{2} & 1 / 2 & 1
\end{array}\right)
$$

A fenti $\mathbf{A}\left(x_{1}, x_{2}\right)$ mátrix semmilyen $x_{1}$ és $x_{2}$ érték mellett sem lesz konzisztens. Ugyan tetszôleges triádját konzisztenssé lehet tenni, mivel mindegyik triádban pontosan egy változó szerepel, az összeset együtt sohasem. A konzisztens kitöltés lehetetlenségét a legegyszerúbben úgy lehet látni, ha a közvetlenül a főátló feletti elemeket, valamint a jobb felsố elemet tekintjük. A fő́atló feletti elemek alapján mindegyik szempont kétszer fontosabb az ôt követônél, azaz a kardinális tranzitivitás alapján az elsô szempontnak $2 \cdot 2 \cdot 2=8$-szor fontosabbnak kellene lennie a negyediknél, viszont ez az arány a jobb felső elem alapján $9, x_{1}$ és $x_{2}$ értékeitôl függetlenül.

Az olyan mátrixok esetén, melyek nem tölthetôek ki konzisztensen, több különbözô módon is számolhatunk súlyvektort. A nem teljesen kitöltött mátrixokra alkalmazott súlyvektor számítási módszerek a teljesen kitöltött mátrixokra vonatkozó módszerek általánosításai. Ezek közül a módszerek közül nem mindegyiknek része, hogy ki is tölti a mátrixot. A konzisztensen kitölthetô mátrixok esetén azonban mindegyikük azt a súlyvektort adja, amely a konzisztens kitöltéshez tartozik. Ezt a tulajdonságot természetes elvárásnak tekinthetjük egy súlyvektor számítási módszerrel szemben. 


\subsubsection{Gráf reprezentáció}

A nem teljesen kitöltött páros összehasonlítás mátrixokhoz adható egy egyszerú és szemléletes gráf reprezentáció, amelynek komoly szerepe lesz a súlyvektor számítási módszereknél. A gráf csúcsai az egyes összehasonlítandó szempontoknak felelnek meg, az élei pedig azoknak a pároknak, amik ténylegesen össze vannak hasonlítva, azaz a hozzá tartozó elem nem hiányzik a mátrixból. Formálisan:

6. Definíció. Az A $n \times n$-es nem teljesen kitöltött páros összehasonlítás mátrixhoz tartozó $G_{\mathbf{A}}(V, E)$ irányítatlan gráf a következô:

$$
\begin{gathered}
V=\{1, \ldots, n\}, \\
E=\left\{e(i, j) \mid a_{i j}\left(\text { és } a_{j i}\right) \text { adott }, i \neq j\right\} .
\end{gathered}
$$

Speciálisan egy teljesen kitöltött mátrixhoz tartozó gráf az $n$ pontú teljes gráf, azaz $K_{n}$. Az $i \neq j$ kikötésnek köszönhetően nincsenek hurokélek a gráfban.

Példaként tekintsük a következô nem teljesen kitöltött páros összehasonlítás mátrixot:

$$
\left(\begin{array}{cccccc}
1 & 2 & - & - & 5 & - \\
1 / 2 & 1 & 2 & - & 1 / 3 & 4 \\
- & 1 / 2 & 1 & 1 / 4 & - & 7 \\
- & - & 4 & 1 & 3 & - \\
1 / 5 & 3 & - & 1 / 3 & 1 & 2 \\
- & 1 / 4 & 1 / 7 & - & 1 / 2 & 1
\end{array}\right)
$$

Itt 6 összehasonlítandó elem van, jelöljük ốket sorban $\{1,2,3,4,5,6\}$-al. Így $V$, azaz a gráf csúcsai is ugyanez a halmaz lesz. A mátrixból hiányzik az $1-3,1-4,1-6,2-4,3-5$, és a $4-6$ összehasonlítás. A mátrixhoz tartozó gráf így a következô lesz: 


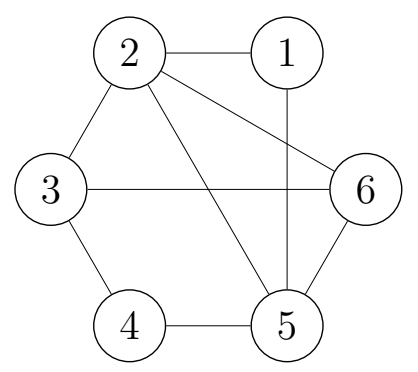

2.1. ábra. A fenti mátrixhoz tartozó gráf

Ha az összehasonlítandó elemeket átrendezzük, az az indexek permutációját jelenti, egy (nem teljesen kitöltött) páros összehasonlítás mátrix esetén pedig a sorok és oszlopok megfelelő átrendeződését. Ha egy ilyen átrendezést hajtunk végre, az a mátrixhoz tartozó gráfot izomorfia erejéig nem befolyásolja. Ha egy mátrix gráfja nem összefüggő, akkor az összehasonlítandó elemek alkalmas átrendezésével a mátrix blokkokra esik szét az összefüggő komponenseknek megfelelően. Ilyenkor a blokkokhoz tartozó komponensekre legfeljebb külön-külön lehet súlyvektor becslést készíteni, mert a teljes rendszerre vonatkoztatva nem lesz egyértelmú a megoldás. Tekintsük például a következô mátrixot:

$$
\left(\begin{array}{cccc}
1 & 1 & - & - \\
1 & 1 & - & - \\
- & - & 1 & 1 \\
- & - & 1 & 1
\end{array}\right)
$$

Ennek a mátrixnak a gráfja az $(1,2)$ és a $(3,4)$ élból áll. Itt az 1-es és 2-es elem egyformán jó/fontos, illetve a 3-as és 4-es elem is egyformán jó/fontos. Azonban mivel nincs köztük összehasonlítás, ezért például az $(1,1,1,1)^{\top}$ és az $(1,1,2,2)^{\top}$ súlyvektor is megfelelő. A gráf összefüggősége tehát szükséges feltétel a megoldás egyértelmúségéhez.

Egy említésre méltó speciális eset az, amikor a mátrixhoz tartozó gráf éppen egy feszítőfa. Ilyenkor minden elempár közvetlen vagy közvetett összehasonlítása csak egyféleképpen van megadva. Emiatt a mátrixot konzisztensen 
ki lehet tölteni, és ez a kitöltés egyértelmú. Ha az $a_{i j}$ hiányzó elemet akarjuk kitölteni, akkor a feszítôfában az $i$-ból $j$-be vezetô egyértelmú út mentén adott elemeket kell összeszoroznunk (hasonlóan a 2.3.4. alfejezet Feszítôfákon alapuló megközelítés címú pontjában leírtakhoz).

\subsubsection{Súlyvektor számítási módszerek a nem teljesen ki- töltött mátrixok esetében}

Számos, a teljesen kitöltött mátrixokra alkalmazott súlyvektor számítási módszert ki lehet terjeszteni a nem teljesen kitöltött esetre. A következőekben a két legelterjedtebb módszert, a sajátvektor módszer és a logaritmikus legkisebb négyzetek módszerének kiterjesztését tekintjük át.

\section{Sajátvektor módszer}

A sajátvektor módszer kiterjesztésére elôször Harker javasolt egy módszert [42]. Két elem, $i$ és $j$ összehasonlításakor minden $i$-ből $j$-be vezetô út mentén kialakított értékelés egy egyéni értékelésnek tekinthetô egy csoportos döntéshozatalban. Így a gráfban lévő összes ilyen út mentén számolt összehasonlítás mértani közepét véve kitölthetjük a felsô háromszögben lévô hiányzó elemeket. Az alsó háromszögbeli hiányzó elemek a felsôk megfelelô elemeinek reciprok értékét kapják. Az így kitöltött mátrixból ezután a standard sajátvektor módszerrel számolható súlyvektor. Aczél és Saaty megmutatta [6], hogy páros összehasonlítás mátrixokat elemenként néhány természetes feltétel (mint például a reciprokszimmetria megốrzése) mellett kizárólag az elemenkénti geometriai középpel lehetséges aggregálni (bővebben ld. a 2.6. alfejezetet és a 1. Tételt). Ez az oka annak, hogy az utak mentén számolt összehasonlításokat Harker a mértani középpel aggregálja.

Harker módszerének ötletét többen is felhasználták [17, 59], azonban egy másik megközelítés igen népszerú lett, mely optimális kitöltést is szolgáltat. Shiraishi, Obata és Daigo cikke [75] alapján abból az ötletból indulunk ki, 
hogy a lehetố legkisebb $C R$ inkonzisztenciájú (ld. 2.4.1. alfejezet) kitöltéshez tartozó jobboldali domináns sajátvektort tekintjük súlyvektornak. Mivel egy konkrét kitöltéshez tartozó vektort nézünk, ennek a módszernek megvan az a jó tulajdonsága, hogy nem csak egy súlyvektort, hanem egy kitöltést is szolgáltat.

Mivel a $C R$ inkonzisztencia a domináns sajátérték egy lineáris transzformációja, ezért a lehetô legkisebb $C R$ inkonzisztencia elérése ekvivalens a domináns sajátérték minimalizálásával. Formálisan tehát az $\mathbf{A}(\mathbf{x})$ nem teljesen kitöltött páros összehasonlítás mátrix esetén a következô feladatot kell megoldanunk:

$$
\min _{\mathbf{x}>0} \lambda_{\max }(\mathbf{A}(\mathbf{x})) .
$$

A (2.23) feladat megoldásából származó minimális $\lambda_{\max }$-hoz tartozó sajátvektor lesz a kiterjesztett sajátvektor módszer súlyvektora. Az az $\mathbf{x}$ vektor, ahol ez a minimum felvétetik, szolgáltatja az optimális kitöltést (ld. 5. Definíció).

A (2.23) feladatnak azonban nem mindig létezik egyértelmú megoldása. A (2.22) példán keresztül láttuk, hogy a mátrixhoz tartozó gráf összefüggốsége szükséges feltétel. Bozóki, Fülöp és Rónyai [12] bizonyították be, hogy a gráf összefüggósége nemcsak szükséges, de elégséges is. A (2.23) feladatnak pontosan akkor létezik tehát egyértelmú megoldása, ha $G_{\mathbf{A}}(V, E)$ összefüggó, ami egy intuitív és könnyen ellenőrizhető feltételt ad a kezünkbe: pontosan akkor lehet egyértelmúen számolni egy optimális kitöltést, ha minden elem mindegyik másikkal legalább közvetve össze van hasonlítva.

\section{Logaritmikus legkisebb négyzetek módszere}

A logaritmikus legkisebb négyzetek módszere értelemszerúen terjeszthető ki, így kapjuk az Incomplete Logarithmic Least Squares Method, röviden ILLSM módszert. A (2.10) célfüggvényt csak azokra az $a_{i j}$ mátrixelemekre írjuk fel, 
amelyek adottak. Tehát

$$
\begin{gathered}
\min \sum_{\substack{i, j=1 \\
a_{i j} \text { adott }}}^{n}\left(\log a_{i j}-\log \frac{w_{i}}{w_{j}}\right)^{2} \\
\sum_{i=1}^{n} w_{i}=1 \\
w_{i}>0, \quad i=1, \ldots, n .
\end{gathered}
$$

Az, hogy $a_{i j}$ adott, ekvivalens azzal, hogy a mátrixhoz tartozó gráfban, $G_{\mathbf{A}}(V, E)$-ben $e(i, j) \in E$.

Bozóki, Fülöp és Rónyai a logaritmikus legkisebb négyzetek módszerére is bizonyította [12], hogy a (2.24) feladatnak pontosan akkor van egyértelmú megoldása, ha a mátrixhoz tartozó gráf összefüggó, azaz minden elem minden másik elemmel össze van hasonlítva, közvetlenül vagy közvetve.

Ugyancsak Bozóki, Fülöp és Rónyai mutatta meg [12], hogy a logaritmikus legkisebb négyzetek módszere megoldható egy lineáris egyenletrendszer megoldásával. Legyen $y_{i}=\log w_{i}, r_{i j}=\log a_{i j}$ a kitöltött elemekre, valamint a normalizálás legyen $w_{n}=1\left(y_{n}=0\right)$. Jelölje $\mathbf{L}$ a $G_{\mathbf{A}}(V, E)$ gráf Laplacemátrixát, amelyben a fóátló $i$-edik sorában az $i$ csúcs fokszáma van, egy főátlón kívüli $(i, j)$ pozícióban pedig -1 , ha $e(i, j) \in E$, és 0 egyébként. Másképpen fogalmazva a fóátlóban az a szám áll minden elem sorában, amennyi elemmel össze van hasonlítva, és azon elemek oszlopában áll -1, amelyekkel van összehasonlítás, és 0 azon elemek oszlopában, amelyekkel nincs. A föátlóban tehát a fokszámok állnak, a többi helyen pedig a gráf szomszédsági mátrixának -1-szerese.

Legyen $\mathbf{L}_{(n-1) \times(n-1)}$ a Laplace-mátrix bal felső $(n-1) \times(n-1)$-es részmátrixa, tehát amit úgy kapunk, hogy L-ról levágjuk az utolsó sort és oszlopot. Jelölje továbbá $r_{i}=\sum_{j} r_{i j}=\log \prod_{j} a_{i j}$, ezek vektorát pedig $\mathbf{r}$. Hasonlóan, legyen $\mathbf{y}_{(n-1)}$ és $\mathbf{r}_{(n-1)}$ az $\mathbf{y}$ és $\mathbf{r}$ vektor az utolsó elem nélkül. Ekkor

$$
\mathbf{L}_{(n-1) \times(n-1)} \mathbf{y}_{(n-1)}=\mathbf{r}_{(n-1)},
$$


azaz

$$
\mathbf{y}_{(n-1)}=\mathbf{L}_{(n-1) \times(n-1)}^{-1} \mathbf{r}_{(n-1)}
$$

Itt $\mathbf{L}_{(n-1) \times(n-1)}$ pontosan akkor invertálható, ha $G_{\mathbf{A}}(V, E)$ összefüggő [12]

Tekintsük például a következô mátrixot:

$$
\left(\begin{array}{ccccc}
1 & 2 & 5 & - & - \\
1 / 2 & 1 & - & 1 / 4 & 7 \\
1 / 5 & - & 1 & 1 / 8 & - \\
- & 4 & 8 & 1 & 2 \\
- & 1 / 7 & - & 1 / 2 & 1
\end{array}\right)
$$

Ennek a Laplace-mátrixa

$$
\mathbf{L}=\left(\begin{array}{ccccc}
2 & -1 & -1 & 0 & 0 \\
-1 & 3 & 0 & -1 & -1 \\
-1 & 0 & 2 & -1 & 0 \\
0 & -1 & -1 & 3 & -1 \\
0 & -1 & 0 & -1 & 2
\end{array}\right)
$$

Így a megoldandó egyenletrendszer, $\mathbf{L}_{4 \times 4} \mathbf{y}_{4}=\mathbf{r}_{4}$ a következő formát ölti:

$$
\left(\begin{array}{cccc}
2 & -1 & -1 & 0 \\
-1 & 3 & 0 & -1 \\
-1 & 0 & 2 & -1 \\
0 & -1 & -1 & 3
\end{array}\right)\left(\begin{array}{l}
y_{1} \\
y_{2} \\
y_{3} \\
y_{4}
\end{array}\right)=\left(\begin{array}{c}
\log (2 \cdot 5) \\
\log \left(\frac{1}{2} \cdot \frac{1}{4} \cdot 7\right) \\
\log \left(\frac{1}{5} \cdot \frac{1}{8}\right) \\
\log (4 \cdot 8 \cdot 2)
\end{array}\right)=\left(\begin{array}{c}
\log 10 \\
\log 7 / 8 \\
\log 1 / 40 \\
\log 64
\end{array}\right)
$$

Innen $y_{1} \approx 1,521, y_{2} \approx 1,006, y_{3} \approx-0,268, y_{4} \approx 1,633$. A keresett $w_{i}$ értékeket $y_{i}=\log w_{i}$ miatt $w_{i}=e^{y_{i}}, i=1, \ldots, 4$ módon kapjuk, valamint $w_{5}=1$. Így a végsố súlyok $w_{1} \approx 4,575, w_{2} \approx 2,736, w_{3} \approx 0,765, w_{4} \approx 5,117$ és $w_{5}=1$, amelyek igény esetén átnormálhatók, például a (2.24)-ben is szereplő $\sum_{i=1}^{n} w_{i}=1$ szerint. 


\section{Optimális kitöltés}

Nem teljesen kitöltött mátrixok optimális kitöltésére is szükségünk lehet. A sajátvektor módszer teljesen közvetlenül szolgáltat egy, a $C R$ indexre optimális (minimális) kitöltést, és ebból számol súlyvektort. A logaritmikus legkisebb négyzetek módszere esetén ez azonban nem ilyen egyértelmú, itt kitöltés nélkül közvetlenül számoljuk a súlyvektort. A súlyvektor elemeinek arányait visszaírhatjuk a mátrix megfelelő kitöltetlen pozícióiba, azonban errôl ránézésre nem világos, hogy megfelelő eredményre vezet.

A sajátvektor módszer esetén ha az optimálisan kitöltött mátrixból újra számolunk egy súlyvektort, az természetesen ugyanaz lesz, mint amit elsôre kaptunk. Ezt a kritériumot kell teljesítenie a logaritmikus legkisebb négyzetes kitöltésnek is ahhoz, hogy azt mondhassuk, hogy a kitöltés a célfüggvényre nézve optimális. A következô állítás új eredmény, a felvetés tôlem származik, a bizonyítás pedig Bozóki Sándortól.

1. Állítás. A nem teljesen kitöltött páros összehasonlítás mátrixokra vonatkozó logaritmikus legkisebb négyzetek módszere (ILLSM) optimális kitöltést ad a hiányzó elemek $a_{i j}=\frac{w_{i}^{I L L S M}}{w_{j}^{I L L S M}}$ helyettesitésével.

Bizonyítás. Legyen adott egy A nem teljesen kitöltött mátrix, és legyen $G=G_{\mathbf{A}}(V, E)$ az ehhez tartozó gráf. Legyen továbbá $G^{C}$ a $G$ gráf komplementere, amelynek a csúcsai azonosak, de pontosan azok az élek vannak behúzva, amelyek $G$-ben nem. Ekkor $G \cup G^{C}=K_{n}$, tehát az uniójuk kiadja a teljes gráfot. Hasonlóan, legyen $\mathbf{L}_{G}, \mathbf{L}_{G^{C}}$ és $\mathbf{L}_{K_{n}}$ a hozzájuk tartozó megfelelő Laplace-mátrix. Ekkor $\mathbf{L}_{G}+\mathbf{L}_{G^{C}}=\mathbf{L}_{K_{n}}$, hiszen $G$ és $G^{C}$ éldiszjunktak.

Legyen y a G-ból számolt súlyvektor elemenkénti logaritmusa, azaz ahogy 
korábban is, $\mathbf{y}=\log \mathbf{w}$. A bizonyítandó állítás tehát:

$$
\mathbf{L}_{K_{n}} \cdot \mathbf{y}=\left(\begin{array}{c}
\log \left(\prod_{\substack{k=1 \\
(1, k) \in E(G)}}^{n} a_{1, k} \cdot \prod_{\substack{l=1 \\
(1, l) \in E\left(G^{C}\right)}}^{n} \frac{w_{1}}{w_{l}}\right) \\
\vdots \\
\log \left(\prod_{\substack{k=1 \\
(n, k) \in E(G)}}^{n} a_{n, k} \cdot \prod_{\substack{l=1 \\
(n, l) \in E\left(G^{C}\right)}}^{n} \frac{w_{n}}{w_{l}}\right)
\end{array}\right) .
$$

Ez az állítás ekvivalensen átírható a következôre:

$$
\mathbf{L}_{K_{n}} \cdot \mathbf{y}=\left(\begin{array}{c}
\log \left(\prod_{\substack{k=1 \\
(1, k) \in E(G)}}^{n} a_{1, k}\right)+\sum_{\substack{l=1 \\
(1, l) \in E\left(G^{C}\right)}}^{n}\left(y_{1}-y_{l}\right) \\
\log \left(\prod_{\substack{k=1 \\
(n, k) \in E(G)}}^{n} a_{n, k}\right)+\sum_{\substack{l=1 \\
(n, l) \in E\left(G^{C}\right)}}^{n}\left(y_{n}-y_{l}\right)
\end{array}\right) .
$$

A jobb oldal két formája közül az elsô, (2.26)-beli alak azt mutatja, hogy a kitöltött mátrixban minden elemet össze kell szorozni a logaritmuson belül, az elsố produktumban az eredeti mátrixelemek vannak, a másodikban pedig a logaritmikus legkisebb négyzetekkel számolt súlyvektor elemeinek arányai a hiányzó pozíciókon. A második, (2.27) alak ennek az átírása az $y_{i}$-ket felhasználva.

$\mathrm{Az} \mathbf{L}_{K_{n}}=\mathbf{L}_{G}+\mathbf{L}_{G^{C}}$ összefüggést felhasználva a bal oldalt két tag összegére bonthatjuk. A (2.27)-ben a jobb oldalon lévô vektor is felírható két tag 
összegeként, így az egyik kapott egyenlet:

$$
\left.\mathbf{L}_{G} \cdot \mathbf{y}=\left(\begin{array}{c}
\log \left(\prod_{\substack{k=1 \\
(1, k) \in E(G)}}^{n} a_{1, k}\right) \\
\vdots \\
\log \left(\prod_{\substack{k=1 \\
(n, k) \in E(G)}}^{n} a_{n, k}\right.
\end{array}\right)\right) .
$$

Ez az egyenlőség teljesül, mert ez egyszerúen a (2.25) összefüggés, amiből az y vektort számoljuk. A másik egyenlet:

$$
\mathbf{L}_{G^{C}} \cdot \mathbf{y}=\left(\begin{array}{c}
\sum_{\substack{l=1 \\
(1, l) \in E\left(G^{C}\right)}}^{n}\left(y_{1}-y_{l}\right) \\
\vdots \\
\sum_{\substack{l=1 \\
(n, l) \in E\left(G^{C}\right)}}^{n}\left(y_{n}-y_{l}\right)
\end{array}\right) .
$$

Azt, hogy ez teljesül, láthatjuk, ha felírjuk $G^{C}$ Laplace-mátrixát:

$$
\left(\begin{array}{cccc}
d_{1}^{C} & 0 & -1 & \ldots \\
0 & d_{2}^{C} & 0 & \ldots \\
\vdots & & & \\
\ldots & 0 & -1 & d_{n}^{C}
\end{array}\right) \cdot \mathbf{y}=\left(\begin{array}{c}
\sum_{\substack{l=1 \\
(1, l) \in E\left(G^{C}\right)}}^{n}\left(y_{1}-y_{l}\right) \\
\vdots \\
\sum_{\substack{l=1 \\
(n, l) \in E\left(G^{C}\right)}}^{n}\left(y_{n}-y_{l}\right)
\end{array}\right)
$$

$L_{G^{C}}$-ben a nullák és -1-ek elhelyezkedése nem feltétlenül pont ilyen, pontosan ott van -1 , ahol az eredeti $G$ gráfban nem volt él. Itt $d_{i}^{C}=n-1-d_{i}$.

Ha a mátrixszorzást elvégezzük, akkor éppen annyiszor lesz az $i$-edik sorban +1 -es együtthatóval $y_{i}$, amennyi $G^{C}$-ben az $i$-edik csúcs fokszáma $\left(d_{i}\right)$, 
és minden más $y_{j}$, ahol $(i, j) \in G^{C}$, egy -1-es együtthatóval. Azaz (2.30) bal oldala tovább írható erre az alakra:

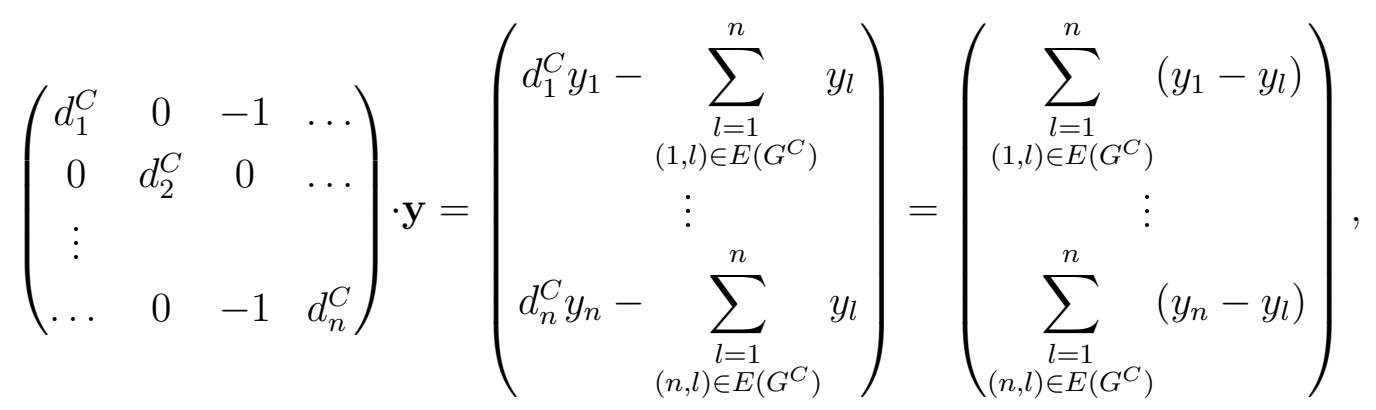

ahol az utolsó alak már ugyanaz, mint (2.29) jobb oldala, tehát (2.29) is teljesül. Mivel (2.28) és (2.29) összeadásával a bizonyítandó állítást, (2.26)-t kapjuk, ezért az állítást igazoltuk.

\section{Egyéb módszerek}

Bármely távolságminimalizáló módszer felírható nem teljesen kitöltött páros összehasonlítás mátrixok esetére is úgy, hogy a hiányzó elemeket nem vesszük figyelembe. Például a legkisebb négyzetek módszerének természetes kiterjesztése a következô optimalizálási feladat:

$$
\min \sum_{\substack{i, j=1 \\ a_{i j} \text { adott }}}^{n}\left(a_{i j}-\frac{w_{i}}{w_{j}}\right)^{2},
$$

melyet még egy normalizálással el kell látni. Sajnos a legkisebb négyzetek módszerének rossz tulajdonságai továbbra is megmaradnak. Továbbra sem elégséges feltétel a megoldás egyértelműségére a mátrixhoz tartozó gráf összefüggősége, hiszen a teljesen kitöltött esetben sem volt ez garantálható, pedig az ehhez tartozó gráf az $n$ pontú teljes gráf. Hasonlóan írható fel például a súlyozott legkisebb négyzetek módszerének kiterjesztése, illetve bármely, eltérések összegét minimalizáló módszer: csak azok a tagok szerepelnek a szummában, amelyekre $a_{i j}$ adott. Ugyancsak hasonló az olyan távolságminimalizáló módszerek kiterjesztése, amelyek nem összeget, hanem például leg- 


\subsection{PÁROS ÖSSZEHASONLÍTÁS MÁTRIXOK ÉS A MÉRTANI KÖZÉP57}

nagyobb eltérést minimalizálnak. Így például a legkisebb legrosszabb négyzet esetén a 2.3.4. alfejezetben tárgyaltak szerint a minimalizálandó célfüggvény:

$$
\max _{\substack{i \neq j \\ a_{i j} \text { adott }}}\left(a_{i j}-\frac{w_{i}}{w_{j}}\right)^{2} .
$$

Itt is szükség van még normalizálásra. A logaritmikus legkisebb négyzetek módszeréhez hasonlóan ezek a módszerek sem közvetlenül egy kitöltésból számolják a súlyvektort, a súlyvektor megfeleló elemeinek arányait azonban be lehet írni a hiányzó helyekre. Azonban míg a sajátvektor módszer esetén eleve egy optimális kitöltésból számolunk súlyvektort, a logaritmikus legkisebb négyzetek esetén pedig a kitöltés optimalitását az 1. Állítás garantálja, addig a többi módszer esetén a kitöltés optimalitása még tisztázandó.

A 2.3.4. alfejezetben bemutatott feszítőfákon alapuló módszer is kiterjeszthetô a nem teljesen kitöltött esetre. Annyi a különbség, hogy a mátrixhoz tartozó gráf nem a teljes gráf, viszont mindenképpen összefüggó. A nem teljes gráf összes feszítőfájához kiszámoljuk a hozzá tartozó konzisztens kitöltést, és az ahhoz tartozó súlyvektort, majd ezeket aggregáljuk. Itt is a két természetes aggregálási módszer a vektorok aritmetikai, illetve mértani közepe. A kitöltött esetre Lundy, Siraj és Greco [61], a nem teljesen kitöltött esetre pedig Bozóki és Tsyganok [10] mutatta meg, hogy a mértani középpel számolt eredmény ugyanaz, mint a logaritmikus legkisebb négyzetek módszerével számolt súlyvektor.

\subsection{Páros összehasonlítás mátrixok és a mértani közép}

Láthattuk, hogy a páros összehasonlítás mátrixok bemutatása közben többször is elókerült a mértani közép használata. Az elsố és talán legalapvetôbb megjelenés a logaritmikus legkisebb négyzetek módszere esetén fordul elő, 
mely bár egy négyzetes logaritmikus célfüggvényt minimalizál, kitöltött esetben az optimális súlyvektort éppen a soronkénti mértani közép adja (2.3.3. alfejezet).

A mértani közép egy másik fontos megjelenése a feszítőfákon alapuló súlyvektor számítási módszer esetén volt mind a kitöltött (2.3.4. alfejezet), mind a nem teljesen kitöltött (2.5.2. alfejezet) esetén. Itt a mátrixhoz tartozó gráf összes lehetséges feszítőfája mentén vett konzisztens kitöltések aggregálására az egyik kézenfekvô módszer a mértani közép. Az is megmutatható, hogy az így számolt súlyvektor ugyanaz, mint a logaritmikus legkisebb négyzetek módszerével számolt [10,61].

A mértani közép egy harmadik, igen lényeges megjelenése a csoportos döntéshozatalban van. Csoportos döntések esetén minden döntéshozó kitölt egy páros összehasonlítás mátrixot, melyeket valamilyen módon aggregálva kapjuk meg azt az aggregált páros összehasonlítás mátrixot, melyból a csoportos döntésnek megfelelô súlyvektort számolhatjuk. Az aggregálás módja azonban lényeges kérdés. Aczél és Saaty bizonyították [6], hogy néhány alapvetô feltétel megkövetelése esetén ha elemenként akarjuk a mátrixot aggregálni, akkor ezt csak a mértani középpel tehetjük meg.

Az első feltétel az a már említett tulajdonság, hogy az aggregálás elemenként történjen. A második tulajdonság az, hogy kváziaritmetikai középpel aggregáljunk, azaz az $f$ aggregáló függvénynek az alábbi alakúnak kell lennie, ha $x_{i}$ az $i$ döntéshozó mátrixeleme:

$$
f\left(x_{1}, x_{2}, \ldots, x_{m}\right)=\phi^{-1}\left(\frac{\sum_{k=1}^{m} \phi\left(x_{k}\right)}{m}\right),
$$

ahol $m$ a döntéshozók száma, $\phi$ pedig tetszóleges folytonos, szigorúan monoton növekvố függvény. Kváziaritmetikai közép a számtani, a mértani, a harmonikus és a hatványközepek is. A kváziaritmetikai közepek teljesítik azt a feltételt, hogy pozitív számok aggregátuma pozitív, illetve hogy

$$
f(x, x, \ldots, x)=x .
$$




\subsection{PÁROS ÖSSZEHASONLÍTÁS MÁTRIXOK ÉS A MÉRTANI KÖZÉP59}

Ez utóbbi a mi esetünkben azt jelenti, hogy konszenzus esetén az aggregátum is visszaadja a közös egyhangú véleményt.

A harmadik feltétel az, hogy a páros összehasonlítás mátrixok tulajdonságával összhangban tartsa a reciprok tulajdonságot, azaz

$$
f\left(\frac{1}{x_{1}}, \frac{1}{x_{2}}, \ldots, \frac{1}{x_{m}}\right)=\frac{1}{f\left(x_{1}, x_{2}, \ldots, x_{m}\right)} .
$$

Ez a feltétel azt jelenti, hogy ha mindenki az ellenkezőjére (reciprokára) változtatja a véleményét, akkor a csoportos döntés is az ellenkezôjére változik.

A negyedik feltétel a pozitív homogenitás, azaz

$$
f\left(s x_{1}, s x_{2}, \ldots, s x_{m}\right)=s f\left(x_{1}, x_{2}, \ldots, x_{m}\right) \quad \forall s>0 .
$$

Ez a feltétel általában skálainvarianciát jelentene, mivel azonban itt arányszámokról van szó, ezért ez esetben azt jelenti, hogy ha minden döntéshozó $s$-szer nagyobbnak értékel egy arányt egy másiknál, akkor az aggregátumban is $s$-szer nagyobbnak kell lennie.

1. Tétel (Aczél-Saaty [6]). A fenti négy feltétel (elemenkénti aggregálás, kváziaritmetikai közép, reciprocitás, pozitiv homogenitás) teljesülése esetén az egyetlen lehetséges aggregálási függvény a mértani közép:

$$
f\left(x_{1}, x_{2}, \ldots, x_{m}\right)=\sqrt[m]{\prod_{k=1}^{m} x_{k}}
$$

A különbözô módon való átlagszámítás vagy aggregálás nem csak a döntéselméletben fontos, hanem általánosságban is lényegi kérdés. Rapcsák [68, I.2.7 alfejezet] mutat egy olyan példát, ami rávilágít, hogy ha normalizált számok (pl. arányok) átlagolására számtani közepet alkalmazunk, akkor az a rangsor számításánál értelmetlen eredményre vezethet, míg a mértani közepet alkalmazva a probléma nem fordul elö.

Ramanathan és Ganesh [67] rámutat, hogy az elemenkénti mértani középpel való aggregálás nem teljesíti a közösségi döntések körében értelmezett 
Pareto-optimalitást: azt, hogy ha minden döntéshozó A-t preferálja B-vel szemben, akkor a közösségi döntés is. Van den Honert és Lootsma [45] szerint azonban ez nem egy releváns hátrány, mivel a végső aggregátum az összes döntéshozó közötti kompromisszum.

\subsection{Az Analytic Hierarchy Process}

A Saaty által megalkotott $[69,70]$ Analytic Hierarchy Process, röviden AHP döntéstámogatási módszerben jelentek meg először a Saaty által bevezetett páros összehasonlítás mátrixok, és egyben ezeknek a mátrixoknak továbbra is leggyakoribb alkalmazási területe. Az AHP módszer a népszerúségét az egyszerúségének, a páros összehasonlításokon alapuló metódusnak, illetve a látványos strukturálhatóságnak, alszempontokra bonthatóságának köszönheti.

Tegyük fel először, hogy csak egy szempontunk van, és az alternatíváinkat e szerint a szempont szerint szeretnénk értékelni. Ekkor egy páros összehasonlítás mátrixszal, illetve az abból számolt súlyvektorral megadhatjuk a sorrendet. Sót, nem csak egy sorrendet, hanem valamilyen kardinális értékelést is, a súlyvektorban szereplő számok alapján. A kardinális értékelésnek a feladattól függóen tudunk vagy nem tudunk értelmezést tulajdonítani. Mindehhez a döntéshozótól csak azokat a páronkénti összehasonlításokat kell megkérdezni minden alternatívapárra, hogy „az $i$ alternatíva hányszor jobb a $j$ alternatívánál a vizsgált szempontból?".

Ha több szempont is van, akkor az alternatívákat minden szempont szerint külön értékelve kapunk egy-egy súlyvektort. Azt, hogy ezekból hogyan alakulnak ki a végső értékelések, a súlyvektoroknak a szempontok fontossági súlyaival vett átlagával számolhatjuk ki. A szempontok súlyait ugyanilyen módszerrel adhatjuk meg. Az összes szempontpárra végigkérdezve a „hányszor fontosabb az $i$ szempont a $j$ szempontnál?" kérdést egy páros összehasonlítás mátrixot állíthatunk össze, melyből a szempontok súlyaira vonatkozó 
súlyvektort kapjuk meg.

Az AHP módszer a súlyvektor meghatározására hagyományosan a sajátvektor módszert (2.3.1. alfejezet) használja, a páros összehasonlítás mátrixok inkonzisztenciáját (2.4. alfejezet) pedig a Saaty-féle $C R$ indexszel méri, és a 10\%-os küszöb alatti mátrixokat tekinti elfogadhatónak (2.4.1. alfejezet). A mátrixok elemeit az 1,2,3, ., 9 számok és ezek reciprokai közül veszi [70], megengedve közbülső elemeket is. Ha az összehasonlítandó szempontok vagy alternatívák fontossága vagy értékelése nagyon közel van egymáshoz, akkor az előzőek helyett az 1, 1.1,1.2, ., 1.9 értékekkel és reciprokaikkal tölthetjük fel a mátrixokat [71]. Az AHP módszerben ugyancsak nem megengedettek a nem teljesen kitöltött páros összehasonlítás mátrixok (2.5. alfejezet). Ha ezeknek a feltételeknek valamelyike nem teljesül, például a logaritmikus legkisebb négyzetek módszerével (2.3.3. alfejezet) számoljuk a súlyvektort, vagy nem teljesen kitöltött mátrixok is szerepelnek, akkor már nem konkrétan AHP-ról, hanem egy általánosabb, páros összehasonlítás mátrixokon alapuló módszercsalád egy tagjáról beszélünk.

A szempontok fontosságára összeállított páros összehasonlítás mátrixból - az elóbbiek alapján a sajátvektor módszerrel - kapott súlyvektor elemei értelmezhetőek úgy, hogy a döntés mekkora része történik az egyes szempontok alapján. A kapott vektor elemeivel már súlyozhatóak az egyes szempontok szerinti értékelések súlyvektorai. Továbbá nemcsak a végsố célként elérendô alternatíva rangsort, hanem a szempontsúlyok alapján közvetlenül a szempontok fontossági sorrendjét is megkapjuk.

Formálisabban legyen $n$ alternatíva $A_{1}, A_{2}, \ldots, A_{n}$, valamint $m$ szempont $C_{1}, C_{2}, \ldots, C_{m}$. Jelölje $\mathbf{A}^{(i)}$ az alternatívák $i$ szempont szerinti páros összehasonlítás mátrixát, és $\mathbf{w}^{(i)}$ a hozzá tartozó súlyvektort. Továbbá legyen $\mathbf{C}$ a szempontok fontosságainak páros összehasonlítás mátrixa, és $\mathbf{w}^{(\mathbf{C})}$ a hozzá tartozó súlyvektor. Ekkor az alternatívák végsô értékeléseit, w-t, a következô módon kaphatjuk meg:

$$
\mathbf{w}=w_{1}^{(\mathbf{C})} \mathbf{w}^{(1)}+w_{2}^{(\mathbf{C})} \mathbf{w}^{(2)}+\cdots+w_{m}^{(\mathbf{C})} \mathbf{W}^{(m)} .
$$


Az itt ismertetett összegzési mód az úgynevezett disztributív módszer [68, I.2.3. fejezet], mikor a levélszempontokon is úgy normalizáljuk az értékeléseket, hogy az összegük 1 legyen. Léteznek más összegzési módok is, melyek esetén a levélszempontok szerinti normalizálás úgy zajlik, hogy valamilyen referencia értékhez viszonyítjuk az értékeléseket. Ha a viszonyítási alap minden esetben a legjobb alternatíva, akkor ennek súlyával normalizálunk, ezt hívjuk ideális összegzési módnak [68, I.2.4. fejezet]. Ha viszont a viszonyítási alap valamilyen (szempontonként) elóre meghatározott érték, akkor minősítő összegzési módról beszélünk [68, I.2.5. fejezet].

A fenti a struktúrát a 2.2 ábrával szemléltethetjük, ahol a cél a hasznosság avagy a végsố megelégedés.

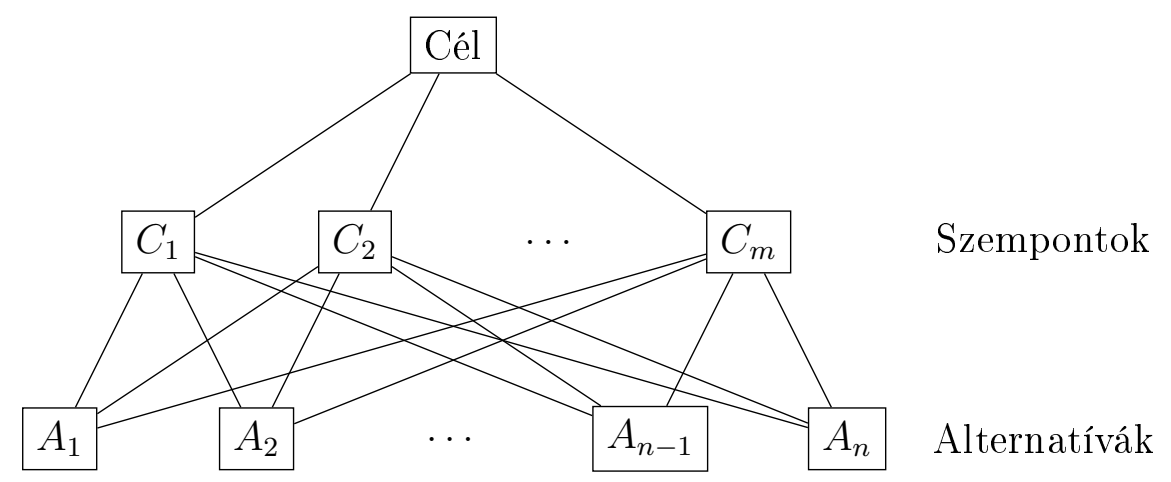

2.2. ábra. Egy egyszintű AHP struktúra

Az AHP módszertannak része, hogy minden szempontnak lehetnek alszempontjai is, azaz minden szempontot még tovább lehet finomítani. Például egy költség szempontnak alszempontja lehet a beszerzési ár (egyszeri) és a fenntartási költség (rendszeres). Az alszempontok bevezetésével egy fa struktúrát kapunk. Azokat a szempontokat, amelyeknek nincsenek alszempontjai, levélszempontoknak hívjuk. Az alternatívákat csak a levélszempontok szerint értékeljük, és az innen kapott súlyvektorokat visszük tovább fölfelé a struktúrában, amíg végül a célhoz nem érünk, és egy végsố rangsort nem kapunk. 
A hierarchiának nagy jelentősége van, mert a magasabb szinten lévô szempontok súlyai hatással vannak az alájuk tartozó, alacsonyabb szinten lévô alszempontok végső, globális súlypontszámaira. Például tegyük fel, hogy a $C_{1}$ szempontnak, melynek súlya legyen 0,5 , két alszempontja van, melyek levélszempontok: $C_{11}$ és $C_{12}$. Legyen $C_{11} 3$-szor fontosabb $C_{12}$-nél. Ekkor az alsó szinten a $C_{11}$ lokális súlya $0,75, C_{12}$-é pedig 0,25 . Mivel azonban $C_{1}$ globális súlya 0,5 , ezért ezzel a számmal beszorozva kapjuk a két alszempont globális súlyát: 0,375 és 0,125 . Tehát míg a lokális súlyok szokásos módon minden szinten egy adott szempont alatt 1-re összegzôdnek, addig a globális súlyok az egyel feljebb lévố fôszempont globális súlyát kell összegként adják.

A levélszempontoknak nem kell azonos szinten lenniük, és bármennyi lehet belőlük. Egy lehetséges többszintú AHP struktúra látható a 2.3. ábrán.

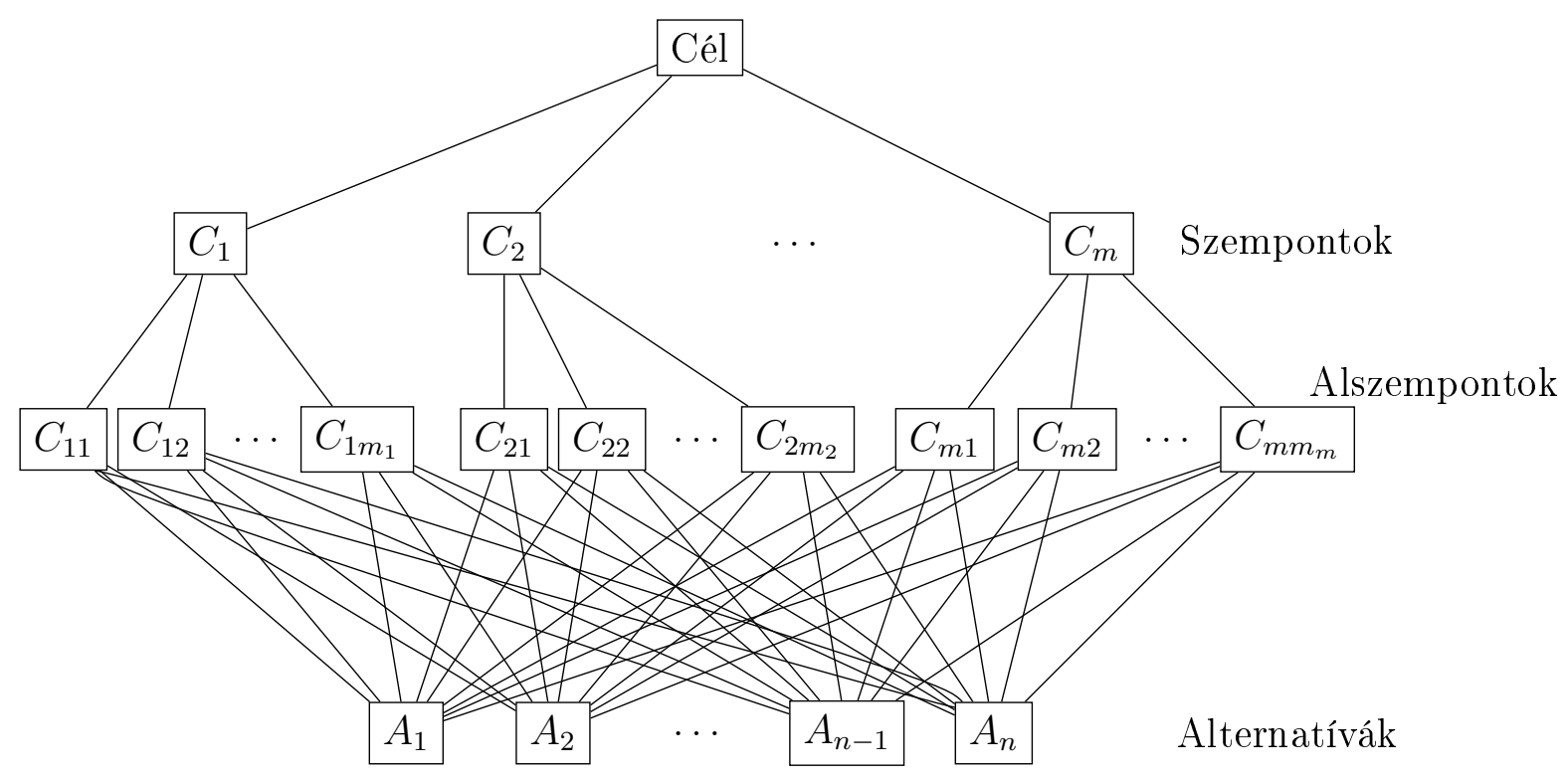

2.3. ábra. Egy többszintû AHP struktúra

Ebben az ábrában ha például $C_{11}, C_{12}, \ldots, C_{1 m_{1}}$ nem lenne, akkor a $C_{1}$ szempont levélszempont lenne, és közvetlenül lenne összekötve az alternatívákkal. Ezen kívül bármelyik alszempontnak is lehetnek saját alszempontjai 
is.

Fontos, hogy egyik alszempont sem lehet több (fó)szempont alá rendelve. Még általánosabban figyelni kell a szempontok függetlenségére, különben bizonyos szempontok túl lehetnek súlyozva. Bonyolult struktúrák esetén a függetlenség biztosítása nehéz feladat, de ez az egyik alapfeltétele az AHP módszer alkalmazhatóságának. Arra az esetre, ha a függetlenség nem teljesül, Saaty javaslata az AHP helyett az ANP (Analytic Network Process) alkalmazása [73]. Az ANP, ahogy a neve is sugallja, a hierarchikus struktúrát egy hálózati struktúrával váltja fel, ahol egy- illetve kétirányú függések is megengedettek.

Egy további variációja az AHP és az ANP módszereknek a fuzzy AHP és ANP [16, 86]. Itt a szokásos módszerekhez képest az a különbség, hogy a mátrixokban szereplô viszonyszámok nem konkrét értékek, hanem bizonytalanságot is megengednek. A bizonytalanságot három szám reprezentálja: egy alsó küszöb, egy középérték és egy felsố korlát. Ha ez a három szám egyezik, akkor nincs bizonytalanság. 


\section{3. fejezet}

\section{Páros összehasonlítás mátrixok gazdasági alkalmazásai}

Ebben a fejezetben a páros összehasonlítás mátrixok, illetve azok nem teljesen kitöltött változatának gazdasági alkalmazásait tekintem át. Az alkalmazások jó része részben vagy teljesen az AHP módszerhez (2.7. fejezet) kötődik, mivel a páros összehasonlítás mátrixok is eredetileg ehhez a módszertanhoz kötődnek.

\subsection{Irodalmi áttekintés}

Az alkalmazások igen sokrétűek a bankszektortól az ipari és gyártási alkalmazásokon át a kormányzati és oktatási felhasználásokig; a makrogazdasági elôrejelzésektốl a marketingen és a logisztikán át a menedzsmentig terjednek. Így jónéhány irodalom-összefoglaló cikk született már csak az AHP alkalmazásokról is. Számos alkalmazás található meg többek között a fent felsorolt területekrôl például a [44], [78], [85] és [87] cikkekben, vagy a [74] könyvben.

Már a felsorolt áttekintő tanulmányok közül a legrégebbi, a Vargas által írt 1990-es [87] áttekintés is 38 gazdasági alkalmazást bemutató publikációt sorol fel, emellett számos politikai, társadalmi és technológiai alkalmazásról 
szóló munkát is.

Időrendben a második, Vaidya és Kumar 2006-os [85] cikke 150, AHP alkalmazásról szóló publikációt tekint át. Ezek közül 26 egyéni döntési témájú, 23 társadalmi, 18 gyártási, 6 politikai, 26 mérnöki, 11 oktatási, 15 ipari, 13 kormányzati és 12 egyéb témájú munka volt. A szerzők kiemelik, hogy ez csupán egy kis szelete az összes AHP alkalmazásról szóló tanulmányoknak. Az összefoglaló áttekintés egyik fô célja a különbözô típusú alkalmazások kategorizálása volt. Itt a típust úgy kell érteni, hogy a legtöbb cikk (32 db) olyan alkalmazást mutatott be, ahol a legjobb alternatíva kiválasztása volt a fô cél, a második legtöbb ( 26 db) kiértékelési feladatot mutatott be, de voltak például rangsorolási (20 db) és elôrejelzési (4 db) problémákkal foglalkozó tanulmányok is. Egy másik érdekességre is rávilágít az összefoglaló cikk: míg eleinte a legtöbb alkalmazásban önmagában használták az AHP-t, addig az idő elôrehaladtával egyre gyakoribb lett annak valamilyen módosítását használni, vagy más módszerekkel, például lineáris programozással vagy neurális hálókkal együtt alkalmazni. Ez a tény a szerzók szerint azt mutatja, hogy az AHP mennyire rugalmas módszer. Az idô előrehaladtával szintén egyre népszerúbb lett az AHP módszer, ugyanis egyre több és több publikáció születik a témában. Az alkalmazások földrajzi eloszlását is vizsgálták, és míg továbbra is az USA a legnagyobb felhasználó, egyre gyakrabban születnek alkalmazások például a fejlődő országokban is.

Azt a Vaidya és Kumar [85] munkájában is megvilágított tényt, miszerint az AHP-t egyre inkább más módszerekkel együtt használják, veti alá részletesebb vizsgálatnak Ho a 2008-as tanulmányában [44]. Az általa vizsgált 66 publikációból 33-ban matematikai programozással együtt használják az AHP-t: lineáris, egészértékú, vegyes, vagy célprogramozással. Ezek a tanulmányok nagyon sokféle területrôl származnak. A legtöbb logisztikai témájú, de találhatóak például gyártási, ipari, marketing és üzleti területen íródott cikkek is. A második legtöbb kategóriában (16 db) az AHP módszert QFD-vel (Quality Function Deployment, magyarul [41] alapján a minőség 
funkcióhoz rendelése) ötvözik. Ezeknek a tanulmányoknak döntő többsége gyártási témájú, de található köztük például oktatási és logisztikai témájú is. A 66-ból 8 cikk használt az AHP mellett metaheurisztikákat. Ezek egy kivételtôl (gyártás) eltekintve mind logisztikai témájú munkák. 5 cikk alkalmazta a SWOT-elemzést (Strengths, Weaknesses, Opportunities, Threaths) az AHP-vel együtt. Ebből az öt cikkből kettô környezeti témájú, illetve egyegy turizmussal, gyártással, illetve mezőgazdasággal foglalkozik. Az utolsó vizsgált csoportba azok a tanulmányok tartoznak, amelyek az AHP mellett DEA-t (Data Envelopment Analysis) használnak. Összesen négy ilyen publikáció volt, amelyekból kettô-kettô kormányzati, illetve gyártási témájú. Az összes tanulmányt összevetve a legtöbb olyan cikk, amely az AHP-t más módszerekkel kombinálja, logisztikai témájú volt (21 db), melyet szorosan követ a gyártási felhasználás (18 db). Ha a matematikai programozás kategóriát kibontjuk, az ilyen típusú kombinált alkalmazások között a célprogramozás a legnépszerúbb. A szerzô szerint ennek oka az, hogy az AHP a konzisztens döntéseket, a célprogramozás pedig az erőforráskorlátokat teszi hozzá a modellhez.

Subramanian és Ramanathan 2012-ben [78] 291 AHP alkalmazásokról szóló publikációt elemzett a termelésmenedzsment területérôl. Ezen belül a vizsgált cikkek 28\%-a foglalkozott termelési stratégiával, 27\% ellátási láncokkal, $23 \%$ termék- és termeléstervezéssel, $13 \%$ projekt menedzsmenttel, és $9 \%$ erőforrás tervezés és időzítéssel. Ha kisebb témákra bontjuk az előbbi öt nagyot, akkor azt látjuk, hogy a legnépszerúbb téma a logisztika és ellátási lánc menedzsment (55 a 291-ból), míg néhány terület, például az elôrejelzés és a minőségmenedzsment relatíve ritkán fordul csak elő (8-8 cikk). A szerzôk megjegyzik, hogy meglepetésükre a tanulmányok kicsit több mint fele a gyártási szektorral kapcsolatos, míg csak a maradék foglalkozik a szolgáltatói szektorral. Ez azért meglepó, mert a szolgáltatói szektorban tipikusan több a szubjektív, nem kézzelfogható tényezô, ami az AHP és hasonló módszerek alkalmazását igencsak indokolttá tennék. A szerzôk szerint valószínúleg az 
az ok, hogy a szolgáltatói szektor virágzása a késő '90-es években kezdődött, így ez az arány idôvel növekedni fog.

A fenti, kizárólag AHP-val foglalkozó összefoglaló cikkeken kívül is fellehetôek olyanok, amelyek foglalkoznak a témával. Például Steuer és Na 2003-ban [77] a többszempontú döntéselméleti módszerek alkalmazását vizsgálta pénzügyi területen. Ôk 18 AHP-t alkalmazó cikket soroltak fel csak a pénzügyekkel kapcsolatosan. Továbbá a frissebb alkalmazások között említést érdemel Csató két tanulmánya, melyek közül az egyik sakk csapatok rangsorolásával [24], a másik felsôoktatási rangsorokkal [25] foglalkozik. Szintén említendô Petróczy [63] cikke, melyben országok életminőség rangsorát állapítja meg a külföldön dolgozók hazautalásai alapján felírt nem teljesen kitöltött páros összehasonlítás mátrixból. Ugyancsak (az itt bemutatottól kissé eltérô) nem teljesen kitöltött páros összehasonlítás mátrixokat használ Telcs, Kosztyán és Török [79, 80], akik felsőoktatási intézmények rangsorolásához alkalmazzák ezeket az objektumokat. Orbán-Mihálykó, Mihálykó és Koltay a logaritmikus legkisebb négyzetek módszerét hasonlítja egy általánosított sztochasztikus módszerhez, szintén nem teljesen kitöltött páros összehasonlítás mátrixok esetén [62].

A téma aktualitását mutatja az is, hogy a Google Scholar keresőjében még a 2014-tól megjelenő AHP cikkekre szúrve is több tízezer találat adódik, azaz ez a terület napjainkban is erôsen kutatott.

\subsection{Autóbuszos tömegközlekedés minôségének modellezése}

Ez az alfejezet Duleba, Mishina és Shimazaki [30] cikke alapján egy tömegközlekedési alkalmazást mutat be. A szerzók az autóbuszos tömegközlekedés minőségét modellezik egy háromszintú AHP modellben. Mivel a múködési költségek, például az üzemanyagárak és a bérek emelkednek, ezért a jegyek 
árát nem igazán lehet csökkenteni. Így a fejlesztésben kizárólag a minőség a kérdés, ezért fix árat feltételeznek, azaz a vizsgálatnak nincsen költség eleme. A kutatásban nem szerepeltek alternatívák, csak szempontok és döntéshozók, mert a cél egy olyan döntési keretrendszer kialakítása volt, amely alkalmas közösségi közlekedésfejlesztési projektek közvetlen értékelésére és tendereztetésére.

Három, a tömegközlekedésben érdekelt szereplő, a kormányzat mint fenntartó, a közlekedési társaság mint üzemeltetô, és az utas mint felhasználó szemszögébôl is elemzik a kérdést. Ez azért különösen fontos, mert a három szereplônek egészen eltérố céljai és preferenciái lehetnek, így ha ezt nem vesszük figyelembe, a megvalósuló fejlesztés túl drága lehet és nem biztos, hogy hatékony.

A minőségben szerepet játszó szempontokat a szakirodalomból, illetve a vizsgált városban, a Japánban lévô Yurihonjo városában folytatott elốzetes tanulmányok alapján határozták meg. A cél nem a jelenlegi helyzet elemzése volt, hanem a preferenciák meghatározása a jövőbeni fejlesztésekkel kapcsolatban annak érdekében, hogy iránymutatást adhassanak a legfontosabb fejlesztendő területekrôl.

A háromszintû hierarchia legfelsô szintjén három fốszempont volt: a szolgáltatás minősége, az utazás minôsége és a követhetôség. A második szinten az utazás minôségének három alszempontja az utazás biztonsága, a fizikai komfort és a mentális komfort volt. Ez utóbbi kategóriába például a jármúben tapasztalt látvány, a sofốr udvariassága és hasonló, a mentális érzéseket befolyásoló tényezôket kell érteni. A követhetőség fôszempont alá az áttekinthetôség, az utazás elôtti információk és az utazás alatti információk kerültek alszempontként. Sem az utazás minôsége, sem a követhetôség alszempontjainak nem voltak saját alszempontjai, vagyis ezek már levélszempontok.

A szolgáltatás minősége volt a legösszetettebb főszempont. A második szinten öt alszempontja volt, a megközelíthetôség, a közvetlenség, az időbeli elérhetôség, a sebesség és a megbízhatóság. A megbízhatóságnak nem voltak 
saját alszempontjai. A megközelíthetôség a megállóktól való távolság, illetve a megállók biztonsága és kényelme volt. A közvetlenségnek két alszempontja volt, az átszállás szükségessége és a csatlakozás illeszkedése. Az idôbeli elérhetôség alszempontjai a járatsưrûség és a járatok közlekedési idôszaka. Végül a sebesség szempontnak három alszempontja volt, az utazási idô, a várakozási idô és a megállók elérésének ideje.

A kapott páros összehasonlítás mátrixok inkonzisztenciáját - az értekezés 2.4.1. alfejezetében is tárgyalt - Saaty-féle $C R$ indexszel mérték, és a mátrixok döntő többségének az inkonzisztenciája a 10\%-os küszöb alatt volt, a többit pedig kis módosításokkal a küszöb alá tudták vinni. A szerző́k szerint a mátrixok alacsony inkonzisztenciája annak köszönhetô, hogy nem a szokásos Saaty-féle 1-9 skálát alkalmazták, hanem egy módosított skálát. Az 5-ös értéket tették meg az indifferenciának, és az 5 alatti értékek feleltek meg annak, hogy az összehasonlítandó párból a sor elem kevésbé preferált vagy fontos. Itt az 1-es érték fejezi ki a legerôsebb preferenciát, azaz ha az oszlop elem erôsen preferált a sor elemhez képest, akkor 1-hez közeli értéket használtak, ha pedig preferált, de gyengén, akkor 5-höz közeli értéket. Hasonlóan az 5 feletti értékek azt fejezik ki, hogy a sor elem mennyire preferált a másodikhoz képest, ahol a 9-es értékhez tartozik a legerôsebb preferencia. Azaz, az elôzôhöz hasonlóan, ha a sor elem erôsen preferált a sor elemhez képest, akkor 9 körüli értéket használtak, ha preferált, de gyengén, akkor 5 körülit. Az így kapott eredményeket ezután vissza kellett transzformálni a szokásos arányskálára.

Néhány mátrix különbözô okokból nem lett teljesen kitöltve. A nem teljesen kitöltött mátrixokat a Bozóki, Fülöp és Rónyai [12] cikkében bemutatott ciklikus koordinátákon alapuló - az értekezés 2.5.2. alfejezetében is tárgyalt módszer segítségével töltötték ki. Az egyéni mátrixok aggregálását az AczélSaaty-tétel (1. Tétel) segítségével elemenkénti mértani középpel végezték, a súlyvektorokat pedig sajátvektor módszerrel számolták.

A legfelsố szinten mindhárom döntéshozói körben a szolgáltatás minôsé- 
gének javítása volt a legfontosabb, bár az utasok szerint a követhetôség erôs második helyezett. A második szinten vizsgálva a szempontokat az utasok és a kormányzat szerint a legfontosabb a megközelíthetőség fejlesztése, míg a vállalat szerint az idôbeli elérhetôség. Ezt úgy kell érteni, hogy az összes második szintû alszempontnak az azonos fôszempont alatt lévố alszempontokkal való összevetésébôl származó súlyát beszorozzuk a fôszempont súlyával, így egy rangsor állítható fel az összes második szintú szempont között. A harmadik szinten is hasonló módon felállítható egy rangsor, ám csak négy második szintú szempontnak voltak alszempontjai, így ez inkább csak ezeknek a szempontoknak az összetevôire világít rá. Itt az utasok és a cég szerint a járatsûrűség, a kormányzat szerint az átszállás szükségessége volt a leginkább fejlesztendô terület.

A szerző́k kiemelik, hogy alapvetően az utasok szemszögéből történő vizsgálatnak kellene mérvadónak lennie, hiszen ốk a felhasználók, azaz ók adják a keresletet. A többi szereplố szemszögéből történő vizsgálatot is figyelembe kell venni, csak kisebb súllyal, mint az utasokét.

A kutatás során kapott eredmények késôbb felhasználásra kerültek a mintaként vizsgált városban, illetve ugyanezen prefektúra több városában is [29]. 


\section{4. fejezet}

\section{Pareto-hatékonyság}

A Pareto-hatékonyság - vagy más elnevezéssel Pareto-optimalitás - a közgazdaságtan alapvetô fogalma. Azt fejezi ki, hogy egy elosztást, tevékenységet, stb. nem lehet triviálisan javítani, azaz anélkül javítani valaminek vagy valakinek a helyzetén, hogy ez máshol ne járna kár okozásával.

A Pareto-hatékonyság elég természetes elvárás, egy nem hatékony megoldás mellett nehéz érvelni. Ha még „ránézésre” is egyértelmúen javítható egy megoldás, akkor ezt miért ne tennénk meg?

Kicsit specifikusabban a többszempontú döntéselméletben is természetesen jelenik meg ez a koncepció. Egy alternatíva hatékony, azaz nem dominált, ha nincsen másik alternatíva, amelyik minden szempont szerint legalább ugyanolyan jó, és valamely szempont szerint határozottan jobb.

Általánosságban egy többcélú optimalizálási feladat a következő formában írható fel [33, Chapter 2][76, Chapter 6]:

$$
\min \left\{f_{1}(\mathbf{y}), f_{2}(\mathbf{y}), \ldots, f_{m}(\mathbf{y}), \ldots, f_{M}(\mathbf{y})\right\}
$$

feltéve, hogy $\mathbf{y} \in S$,

ahol $M \geq 2$ a célfüggvények száma és $f_{m}: \mathbb{R}^{n} \rightarrow \mathbb{R}$ minden $1 \leq m \leq M$-re, valamint a változók $\mathbf{y}=\left(y_{1}, y_{2}, \ldots, y_{n}\right)$ és a lehetséges megoldások halmaza $S \subseteq \mathbb{R}^{n}$. Ebben a felírásban mindegyik $f_{m}$ célfüggvény minimalizálandó. 
Egy $\mathbf{y} \in S$ vektort Pareto-hatékonynak (vagy egyszerúen csak hatékonynak, illetve számos forrás Pareto-optimalitásnak nevezi) hívunk, ha nem létezik olyan $\mathbf{y}^{\prime} \in S$ vektor, amire $f_{m}\left(\mathbf{y}^{\prime}\right) \leq f_{m}(\mathbf{y})$ minden $1 \leq m \leq M$-re, és $f_{m}\left(\mathbf{y}^{\prime}\right)<f_{m}(\mathbf{y})$ legalább egy $m$ indexre.

Definiáljuk most a páros összehasonlítás mátrixokból számolt súlyvektorok Pareto-hatékonyságát!

Legyen $\mathbf{A}=\left[a_{i j}\right]_{i, j=1, \ldots, n} \in \mathcal{P C} \mathcal{M}_{n}$ rögzített. Legyen továbbá $\mathbf{w}=$ $\left(w_{1}, w_{2}, \ldots, w_{n}\right)^{\top}$ egy pozitív súlyvektor (ekkor tehát $S=\mathbb{R}_{++}^{n}$, azaz a pozitív ortáns), ahol $n$ a szempontok száma. A célfüggvényeink legyenek $f_{i j}(\mathbf{w}):=\left|a_{i j}-\frac{w_{i}}{w_{j}}\right|$ minden $i \neq j$-re, így $M=n^{2}-n$ célfüggvényünk van. Ilyen keretek között a következő definíciót írhatjuk fel:

7. Definíció. Egy pozitív w súlyvektor hatékony (vagy Pareto-hatékony), ha nem létezik olyan másik pozitív $\mathbf{w}^{\prime}=\left(w_{1}^{\prime}, w_{2}^{\prime}, \ldots, w_{n}^{\prime}\right)^{\top}$ súlyvektor, amire

$$
\begin{array}{ll}
\left|a_{i j}-\frac{w_{i}^{\prime}}{w_{j}^{\prime}}\right| \leq\left|a_{i j}-\frac{w_{i}}{w_{j}}\right| & \text { minden } 1 \leq i, j \leq n \text {-re, és } \\
\left|a_{k \ell}-\frac{w_{k}^{\prime}}{w_{\ell}^{\prime}}\right|<\left|a_{k \ell}-\frac{w_{k}}{w_{\ell}}\right| & \text { valamely } 1 \leq k, \ell \leq n \text {-re. }
\end{array}
$$

A fenti definíció tehát azt jelenti, hogy egy páros összehasonlítás mátrixhoz tartozó súlyvektor akkor hatékony, ha nem lehet a vektor elemeinek változtatásával egy mátrixelem közelítését sem javítani anélkül, hogy más mátrixelem közelítésén ne rontanánk.

1. Megjegyzés. A hatékonyság nem függ a normalizálástól, azaz $\mathbf{w}$ és cw pontosan ugyanakkor hatékony tetszóleges $c>0$ skalár mellett.

2. Állítás. Minden konzisztens páros összehasonlítás mátrix esetén a domináns jobb oldali sajátvektor $\left(\mathbf{w}^{E M}\right)$ hatékony.

Bizonyitás. Konzisztens páros összehasonlítás mátrixok esetén igaz, hogy $a_{i j}=\frac{w_{i}^{E M}}{w_{j}^{E M}}$, azaz $f_{i j}\left(\mathbf{w}^{E M}\right)=0$ minden $i, j=1, \ldots, n$-re [69], ami már nem javítható tovább, hiszen minden közelítés tökéletes. 
A hatékonyság egy természetesen elvárható tulajdonság. Blanquero, Carrizosa és Conde azonban megmutatta, hogy a sajátvektor módszer által adott súlyvektor, azaz a jobboldali domináns sajátvektor nem mindig hatékony [9, Section 3]. Ezt az eredményt hivatkozták Bajwa, Choo és Wedley [8], Conde és Pérez [21], valamint Fedrizzi [36].

Bozóki [11] azt is megmutatta, hogy a hatékonyság az inkonzisztencia mértékétôl sem függ közvetlenül. Az alábbi paraméteres mátrix $C R$ inkonzisztencia mértéke tetszólegesen kicsi lehet, ha $q$ elég közel van 1-hez, viszont domináns sajátvektora nem hatékony:

$$
\mathbf{A}(p, q)=\left(\begin{array}{ccccccc}
1 & p & p & p & \ldots & p & p \\
1 / p & 1 & q & 1 & \ldots & 1 & 1 / q \\
1 / p & 1 / q & 1 & q & \ldots & 1 & 1 \\
\vdots & \vdots & \vdots & \ddots & & \vdots & \vdots \\
\vdots & \vdots & \vdots & & \ddots & \vdots & \vdots \\
1 / p & 1 & 1 & 1 & \ldots & 1 & q \\
1 / p & q & 1 & 1 & \ldots & 1 / q & 1
\end{array}\right) \in \mathcal{P C} \mathcal{M}_{n}
$$

ahol $n \geq 4, p>0$ és $1 \neq q>0$.

Blanquero, Carrizosa és Conde [9] a hatékonyság több szükséges és elégséges feltételét is vizsgálta, melyek közül az alábbi, irányított gráffal adott reprezentációt fogjuk használni.

8. Definíció. Legyen $\mathbf{A}=\left[a_{i j}\right]_{i, j=1, \ldots, n} \in \mathcal{P C} \mathcal{M}_{n}$ és $\mathbf{w}=\left(w_{1}, w_{2}, \ldots, w_{n}\right)^{\top}$ egy pozitív súlyvektor. A $G:=(V, \vec{E})_{\mathbf{A}, \mathbf{w}}$ irányított gráfot a következô módon definiáljuk: $V=\{1,2, \ldots, n\}$ és

$$
\vec{E}=\left\{\operatorname{arc}(i \rightarrow j) \mid \frac{w_{i}}{w_{j}} \geq a_{i j}, i \neq j\right\},
$$

ahol arc $(i \rightarrow j)$ az $i$ csúcsból a $j$ csúcsba vezető irányított élt jelöli.

A definícióban meghatározott irányított gráfban tehát akkor megy egy irányított él az $i$ pontból a $j$ pontba, ha a $w_{i} / w_{j}$ súlyarány felülbecsli az $a_{i j}$ 
mátrixelemet. Tökéletes közelítés esetén, azaz amikor $a_{i j}=w_{i} / w_{j}$, az $i$ és $j$ csúcs között mindkét irányban fut egy-egy irányított él. Az is látható, hogy bármely két csúcs között legalább az egyik irányba mindig fut él.

A 8. Definíció segítségével az alábbi tétel mondható ki:

2. Tétel ([9, Corollary 10]). Legyen $\mathbf{A} \in \mathcal{P C} \mathcal{M}_{n}$. Egy $\mathbf{w}$ pozitív súlyvektor pontosan akkor hatékony, ha $G=(V, \vec{E})_{\mathbf{A}, \mathbf{w}}$ egy erösen összefüggó gráf, azaz minden $i, j$ csúcspárra létezik irányított út $i$-ból $j$-be és $j$-bốl $i$-be.

Nézzünk egy számpéldát a 2. Tétel alkalmazására, és egyben a Paretohatékonyság hiányára.

1. Példa. Legyen $\mathbf{A} \in \mathcal{P C} \mathcal{M}_{4}$ a következô mátrix:

$$
\mathbf{A}=\left(\begin{array}{cccc}
1 & 1 & 1 / 5 & 1 / 5 \\
1 & 1 & 1 / 3 & 1 / 7 \\
5 & 3 & 1 & 1 / 4 \\
5 & 7 & 4 & 1
\end{array}\right)
$$

Az A domináns jobb oldali sajátvektora 8 tizedesjegyre kerekítve, valamint A konzisztens közelítése, melyet $\mathbf{w}^{E M}$ elemeinek arányaiból képzünk, 4 tizedesjegyre kerekítve a következók:

$$
\mathbf{w}^{E M}=\left(\begin{array}{l}
0,07777933 \\
0,07732534 \\
0,24353753 \\
0,60135778
\end{array}\right),\left[\frac{w_{i}^{E M}}{w_{j}^{E M}}\right]=\left(\begin{array}{cccc}
1 & 1,0058 & 0,3193 & 0,1293 \\
0,9941 & 1 & 0,3175 & 0,1285 \\
3,1311 & 3,1495 & 1 & 0,4049 \\
7,7315 & 7,7769 & 2,4692 & 1
\end{array}\right) .
$$

A 8. Definíció segítségével felrajzolható az A-hoz, és a hozzá tartozó jobb oldali domináns sajátvektorhoz, $\mathbf{w}^{E M}$-hez tartozó irányított gráf. Ez a gráf a 4.1. ábrán látható, és nem erôsen összefüggó, mivel a 2-es csúcsot nem hagyja el irányított él. Ekkor a 2. Tétel szerint $\mathbf{w}^{E M}$ nem hatékony. 


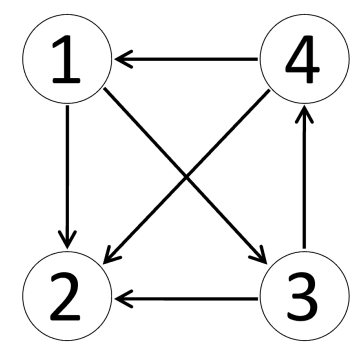

4.1. ábra. Az 1. példában szereplő mátrixhoz tartozó, nem erôsen összefüggő irányított gráf.

A fenti alkalmazás illusztrálja, milyen jól használható és látványos módszert ad a kezünkbe a 8. Tétel. Ellenôrizzük le ezen a példán az eredményt közvetlenül is. Növeljük $w_{2}^{E M}$ értékét $w_{1}^{E M}$-re, azaz legyen $\mathbf{w}^{\prime}:=$ $\left(w_{1}^{E M}, w_{1}^{E M}, w_{3}^{E M}, w_{4}^{E M}\right)^{\top}$. Ekkor

$\mathbf{w}^{\prime}:=\left(\begin{array}{l}0,07777933 \\ 0,07777933 \\ 0,24353753 \\ 0,60135778\end{array}\right),\left[\frac{w_{i}^{\prime}}{w_{j}^{\prime}}\right]=\left(\begin{array}{cccc}1 & \mathbf{1} & 0,3193 & 0,1293 \\ \mathbf{1} & 1 & \mathbf{0 , 3 1 9 3} & \mathbf{0 , 1 2 9 3} \\ 3,1311 & \mathbf{3 , 1 3 1 1} & 1 & 0,4049 \\ 7,7315 & \mathbf{7 , 7 3 1 5} & 2,4692 & 1\end{array}\right)$.

A w' súlyvektor koordinátái ugyan nem 1-re összegződnek, de ez alkalmas skalárral való szorzással elérhetô, ami nem változtatja meg a $w_{i}^{\prime} / w_{j}^{\prime}$ arányokat, ahogyan azt az 1. megjegyzésben tisztáztuk.

A módosított súlyvektorból és a belóle alkotott reciprok mátrixból már látható, hogy a 7. definíciót $\mathbf{w}=\mathbf{w}^{E M}$-re alkalmazva a (4.2)-beli szigorú egyenlőtlenség érvényes a második sor és oszlop diagonálison kívüli, félkövérrel kiemelt elemeire. Az összes többi mátrixelemre (4.1) egyenlôséggel teljesül. Azaz w' három (a reciprokokkal együtt hat) pozícióban is határozottan jobban közelíti $\mathbf{A}$-t, mint $\mathbf{w}^{E M}$, miközben az összes többi pozícióban ugyanolyan jól.

Ahogy az 1. példa is illusztrálja, a nem hatékony és a hatékonnyá tett vektorok között gyakori a meglehetôsen kicsi különbség. Ez egyetlen mátrix 
esetén a kardinális értékeket csak kis mértékben, az ordinális rangsort pedig általában sehogyan sem befolyásolja, így azt gondolhatnánk, hogy ez a különbség ilyen esetben elhanyagolható. Azonban igen fontos, hogy a 2.7. alfejezetben bemutatott módon egy komplex döntési problémában a hierarchia magas szintjén lévô nem hatékony súlyvektor vagy súlyvektorok hatékonnyá tételéból adódó számszerúleg esetleg kis eltérés is végigfut a döntési hierarchia adott ágán, így a változtatás mégis jelentôs mértékben befolyásolhatja a végső alternatíva sorrendet, illetve a súlyokat.

A 2. Tételt felhasználva sikerült elemezni egy speciális mátrixosztály domináns sajátvektorának hatékonyságát, melyrôl a következókben, a 4.1. és a 4.2. alfejezetben lesz szó, amelyek a [3], illetve [4] cikkeink eredményeit mutatják be.

\subsection{Egy elemtôl eltekintve konzisztens páros összehasonlítás mátrixok}

Ebben a fejezetben a [3] cikkünk eredményeit ismertetem.

Vegyünk egy konzisztens páros összehasonlítás mátrixot, és módosítsuk egyetlen (nem fóátlóbeli) elemében és annak reciprokában. Ekkor egy olyan páros összehasonlítás mátrixot kapunk, mely egy elemtól eltekintve konzisztens (angolul simple perturbed, röviden SP). Egy ilyen mátrix az összehasonlítandó elemek átsorszámozásával mindig a következô definícióban szerepló alakra hozható, a konzisztens páros összehasonlítás mátrix (2.4) alakjából kiindulva.

9. Definíció. Egy $\mathbf{A}_{\delta} \in \mathcal{P C} \mathcal{M}_{n}$ páros összehasonlítás mátrix egy elemtól eltekintve konzisztens, ha alkalmas sor- és oszlopcserékkel az alábbi alakra 
hozható:

$$
\mathbf{A}_{\delta}=\left(\begin{array}{ccccc}
1 & \boldsymbol{x}_{\mathbf{1}} \boldsymbol{\delta} & x_{2} & \ldots & x_{n-1} \\
\frac{1}{\boldsymbol{x}_{1} \boldsymbol{\delta}} & 1 & \frac{x_{2}}{x_{1}} & \ldots & \frac{x_{n-1}}{x_{1}} \\
\frac{1}{x_{2}} & \frac{x_{1}}{x_{2}} & 1 & \ldots & \frac{x_{n-1}}{x_{2}} \\
\vdots & \vdots & \vdots & \ddots & \vdots \\
\frac{1}{x_{n-1}} & \frac{x_{1}}{x_{n-1}} & \frac{x_{2}}{x_{n-1}} & \ldots & 1
\end{array}\right)
$$

ahol $0<\delta \neq 1$ és $x_{1}, x_{2}, \ldots, x_{n-1}>0$.

A $\delta=1$ esetben a mátrix konzisztens. Jelölje $\lambda=\lambda_{\delta}$ (az utóbbi jelölést használva, ha a $\delta$-tól való függést akarjuk hangsúlyozni) az $\mathbf{A}_{\delta}$ domináns sajátértékét. Egy SP mátrixot úgy is lehet jellemezni, hogy egy elem (és reciprokának) megváltoztatásával konzisztenssé tehetô. A definícióban szereplő alakban ez az elem az 1. sor 2. eleme (és reciproka).

Ahhoz, hogy az SP mátrixok esetében bizonyíthassuk a sajátvektor módszer hatékonyságát, először az $\mathbf{A}_{\delta}$ domináns sajátvektorának ( $\left.\mathbf{w}^{E M}\right)$ explicit képletére lesz szükségünk, melyek Farkas [34] jóvoltából ismertek. Ezek hasonlóan adódnak, mint Farkas, Rózsa és Stubnya képletei [35] a domináns sajátvektorra abban az esetben, mikor egy egész sor, illetve oszlop elemeit szorozzuk végig ugyanazzal a $\delta$ tényezóvel. Az SP esetre a sajátvektor formulájának egyik alakja [34, (26)-os formula]:

$$
\mathbf{w}^{E M}=\left(\begin{array}{c}
w_{1}^{E M} \\
w_{2}^{E M} \\
\vdots \\
w_{i}^{E M} \\
\vdots
\end{array}\right)=\left(\begin{array}{c}
\lambda-1+\delta \\
\frac{1}{x_{1}}\left(\lambda-1+\frac{1}{\delta}\right) \\
\vdots \\
\frac{1}{x_{i-1}} \lambda \frac{\lambda-2}{n-2} \\
\vdots
\end{array}\right), \quad i=3,4, \ldots, n
$$


Egy másik, ekvivalens alak [34, (24)-es formula]:

$$
\mathbf{w}^{E M}=\left(\begin{array}{c}
w_{1}^{E M} \\
w_{2}^{E M} \\
\vdots \\
w_{i}^{E M} \\
\vdots
\end{array}\right)=c\left(\begin{array}{c}
\lambda(\lambda-n+1) \\
\frac{1}{x_{1}}\left[\lambda-\left(1-\frac{1}{\delta}\right)(\lambda-n+2)\right] \\
\vdots \\
\frac{1}{x_{i-1}}\left(\lambda-1+\frac{1}{\delta}\right) \\
\vdots
\end{array}\right), \quad i=3,4, \ldots, n
$$

ahol a $c$ konstans szorzó értéke $c=\frac{\lambda-1+\delta}{\lambda(\lambda-n+1)}$. Mindkét alakra szükségünk lesz a bizonyításhoz.

A jobb alsó $(n-2) \times(n-2)$-es részmátrixban a közelítés tökéletes, mivel $a_{i j}=\frac{w_{i}^{E M}}{w_{j}^{E M}},(i, j=3, \ldots, n)$. Így csak az elsố két sor és oszlop elemeit kell megvizsgálnunk.

1. Lemma. $H a \delta \gtreqless 1$, akkor $\frac{w_{1}^{E M}}{w_{2}^{E M}} \lesseqgtr a_{12}$.

Bizonyítás. Legyen $\delta>1$. A (4.4) képletbôl az $a_{12}=\delta x_{1}$ közelítése a következô módon írható fel:

$$
\frac{w_{1}^{E M}}{w_{2}^{E M}}=\frac{\lambda-1+\delta}{\frac{1}{x_{1}}\left(\lambda-1+\frac{1}{\delta}\right)}=x_{1} \frac{\lambda-1+\delta}{\lambda-1+\frac{1}{\delta}} .
$$

Azt kell tehát bizonyítanunk, hogy $\frac{\lambda-1+\delta}{\lambda-1+\frac{1}{\delta}}<\delta$, azaz, $\lambda-1+\delta<\delta \lambda-\delta+1$ $\Leftrightarrow 2(\delta-1)<\lambda(\delta-1) \Leftrightarrow 2<\lambda$. Az utolsó egyenlőtlenség azért igaz, mert $\lambda>n \geq 3$. A $\delta<1$ eset hasonlóan bizonyítható, a $\delta=1$ esetben pedig a mátrix konzisztens, így $\frac{w_{1}^{E M}}{w_{2}^{E M}}=a_{12}$.

2. Lemma. Legyen $j>2$. Ha $\delta \gtreqless 1$, akkor $\frac{w_{1}^{E M}}{w_{j}^{E M}} \gtreqless a_{1 j}$.

Bizonyítás. Legyen $\delta>1$. A (4.5) képletból az $a_{1 j}=x_{j-1}(j=3,4, \ldots, n)$ közelítése a következô módon írható fel:

$$
\frac{w_{1}^{E M}}{w_{j}^{E M}}=\frac{\lambda(\lambda-n+1)}{\frac{1}{x_{j-1}}\left(\lambda-1+\frac{1}{\delta}\right)}=x_{j-1} \frac{\lambda(\lambda-n+1)}{\lambda-1+\frac{1}{\delta}} .
$$


Így az állítás a következôvel ekvivalens: $\frac{\lambda(\lambda-n+1)}{\lambda-1+\frac{1}{\delta}}>1 \Leftrightarrow \lambda(\lambda-n+1)>\lambda-1+\frac{1}{\delta}$ $\Leftrightarrow \lambda^{2}-\lambda n+\lambda>\lambda-1+\frac{1}{\delta} \Leftrightarrow\left(\lambda^{2}-\lambda n\right)+\left(1-\frac{1}{\delta}\right)>0$. Itt az első kifejezés $\lambda>n$ miatt pozitív, a második pedig ugyancsak pozitív $\delta>1$ miatt.

Legyen most $\delta<1$. A (4.4) képletból az $a_{1 j}=x_{j-1}(j=3,4, \ldots, n)$ közelítése

$$
\frac{w_{1}^{E M}}{w_{j}^{E M}}=\frac{\lambda-1+\delta}{\frac{1}{x_{j-1}} \lambda \frac{\lambda-2}{n-2}}=x_{j-1} \frac{(n-2)(\lambda-1+\delta)}{\lambda(\lambda-2)} .
$$

Így a cél, hogy a következô egyenlőtlenséget belássuk: $(n-2)(\lambda-1+\delta)<$ $\lambda(\lambda-2) \Leftrightarrow \lambda(n-\lambda)+(\delta-1)(n-2)<0$. Itt az elsố szorzat $\lambda>n$ miatt negatív, a második pedig szintén negatív $\delta<1$ miatt.

A $\delta=1$ esetben a mátrix konzisztens, így $\frac{w_{1}^{E M}}{w_{j}^{E M}}=a_{1 j}$.

3. Lemma. Legyen $j>2$. Ha $\delta \gtreqless 1$, akkor $\frac{w_{2}^{E M}}{w_{j}^{E M}} \lesseqgtr a_{2 j}$.

Bizonyítás. Legyen $\delta>1$. A (4.5) képletból az $a_{2 j}=\frac{x_{j-1}}{x_{1}}(j=3,4, \ldots, n)$ közelítése

$$
\frac{w_{2}^{E M}}{w_{j}^{E M}}=\frac{\frac{1}{x_{1}}\left[\lambda-\left(1-\frac{1}{\delta}\right)(\lambda-n+2)\right]}{\frac{1}{x_{j-1}}\left(\lambda-1+\frac{1}{\delta}\right)}=\frac{x_{j-1}}{x_{1}} \frac{\lambda-\left(1-\frac{1}{\delta}\right)(\lambda-n+2)}{\lambda-1+\frac{1}{\delta}} .
$$

Így az állítás ekvivalens a következôvel: $\frac{\lambda-\left(1-\frac{1}{\delta}\right)(\lambda-n+2)}{\lambda-\left(1-\frac{1}{\delta}\right)} \frac{x_{j-1}}{x_{1}}<\frac{x_{j-1}}{x_{1}} \Leftrightarrow \lambda-$ $\left(1-\frac{1}{\delta}\right)(\lambda-n+2)<\lambda-\left(1-\frac{1}{\delta}\right) \Leftrightarrow-(\lambda-n+2)<-1 \Leftrightarrow \lambda-n>-1 . \mathrm{Az}$ utolsó reláció $\lambda>n$ miatt mindig igaz. A $\delta<1$ eset hasonlóan bizonyítható. A $\delta=1$ esetben a mátrix konzisztens, így $\frac{w_{2}^{E M}}{w_{j}^{E M}}=a_{2 j}$.

Érdemes megjegyezni, hogy míg az 1. és 3. Lemmákhoz elég volt egy képletet használni, addig a 2. Lemmához a $\delta>1$ és $\delta<1$ esetekhez más-más sajátvektor formulára volt szükség.

A fenti lemmák segítségével látjuk be az alábbi tételt:

3. Tétel ([3, Theorem 3.4]). Az egy elemtól eltekintve konzisztens páros összehasonlítás mátrixok jobboldali domináns sajátvektora Pareto-hatékony. 
A tételnek két bizonyítását is bemutatjuk. Az elsô elemi, míg a második a 2. Tételt használja és a későbbi kiterjesztés bizonyításához hasonló. Továbbá a második bizonyításhoz használt 2. Tételben szereplő irányított gráf felrajzolásával szemléletesen bizonyítható egy páros összehasonlítás mátrixhoz tartozó súlyvektorról, hogy hatékony-e vagy sem.

Elsố bizonyítás.

Tegyük fel, hogy $\delta>1$. Továbbá indirekt tegyük fel, hogy létezik egy $\mathbf{w}^{\prime}=\left(w_{1}^{\prime}, w_{2}^{\prime}, w_{3}^{E M}, \ldots, w_{n}^{E M}\right)^{\top}$ súlyvektor, amely $\mathbf{A}_{\delta}$ elemeit legalább olyan jól közelíti, mint $\mathbf{w}^{E M}$, és legalább egy pozícióban szigorúan jobban. Az elsô két komponens kivételével a két vektornak egyeznie kell, mivel a többit $\mathbf{w}^{E M}$ tökéletesen közelíti. A 2. Lemmából látható, hogy $w_{1}^{\prime} \leq w_{1}^{E M}$, míg a 3. Lemmából $w_{2}^{\prime} \geq w_{2}^{E M}$. Az elôzô egyenlôtlenségek közül legalább az egyiknek szigorúnak kell lennie, különben $\mathbf{w}^{\prime}=\mathbf{w}^{E M}$ lenne. Ebból és az 1. Lemmából következik, hogy

$$
\frac{w_{1}^{\prime}}{w_{2}^{\prime}}<\frac{w_{1}^{E M}}{w_{2}^{E M}}<a_{12} .
$$

Ez azt jelenti, hogy $\mathbf{w}^{\prime}$ határozottan rosszabb közelítést ad $a_{12}$-re, mint $\mathbf{w}^{E M}$, ami ellentmond az eredeti feltevésünknek. A $\delta<1$ eset hasonlóan bizonyítható.

Második bizonyítás.

A 8. Definíciót fogjuk felhasználni, azaz az $\mathbf{A}_{\delta}$ páros összehasonlítás mátrixhoz és a hozzá tartozó jobboldali domináns $\mathbf{w}^{E M}$ sajátvektorhoz felrajzoljuk az irányított gráfot. Az $i$ csúcsból a $j$ csúcsba pontosan akkor megy egy irányított él, ha $\frac{w_{i}^{E M}}{w_{j}^{E M}} \geq a_{i j}$. Legyen $\delta>1$. Az 1. Lemmából következik, hogy $(2 \rightarrow 1) \in \vec{E}$ és $(1 \rightarrow 2) \notin \vec{E}$. A 2. Lemmából következik, hogy $(1 \rightarrow j) \in \vec{E}$ és $(j \rightarrow 1) \notin \vec{E}$ minden $j=3,4, \ldots, n$-re. A 3. Lemmából következik, hogy $(2 \rightarrow j) \notin \vec{E}$ és $(j \rightarrow 2) \in \vec{E}$ minden $j=3,4, \ldots, n$ re. Ha $i, j=3,4, \ldots, n, i \neq j$, akkor $a_{i j}=\frac{w_{i}^{E M}}{w_{j}^{E M}}$ esetén $(i \rightarrow j) \in \vec{E}$ és $(j \rightarrow i) \in \vec{E}$. A kapott irányított gráf a 4.2. ábrán látható.

Bármely $i \neq 1,2$ csúcsból vezet él a 2 csúcsba, és 1 -ból vezet él $i$-be. 


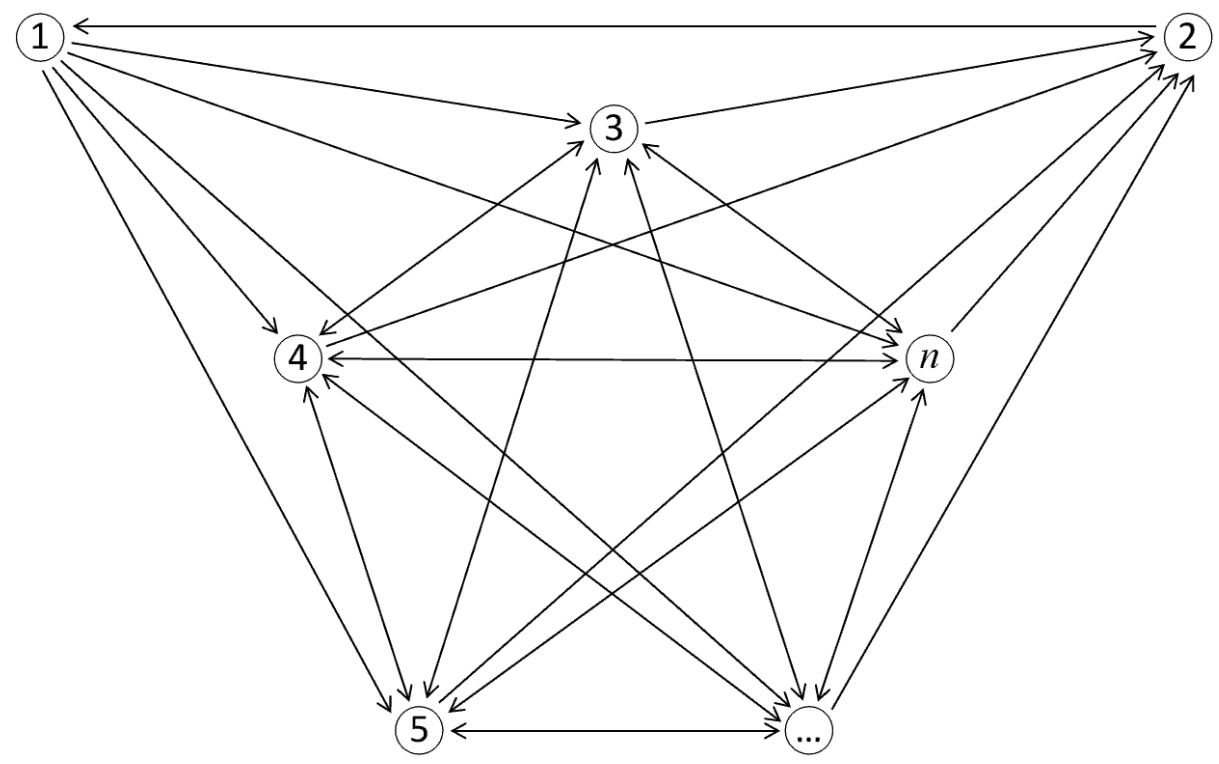

4.2. ábra. Az SP mátrixhoz tartozó erôsen összefüggő irányított gráf.

Továbbá 2-bôl 1-be is vezet él, így bármely csúcsból elérhető 1, onnan pedig bármely más csúcs. Az 1-ból 2-be pedig például az $1-3-2$ úton lehet eljutni. Tehát bármely csúcsból bármely csúcsba el lehet jutni irányított úton, azaz az irányított gráf erôsen összefüggô. Így a 2. Tétel értelmében $\mathbf{w}^{E M}$ Pareto-hatékony.

A $\delta<1$ eset hasonlóan bizonyítható. Ez esetben az irányított gráf ugyanaz mint a 4.2. ábrán, csupán az 1-es és 2-es csúcsok vannak felcserélve.

Mivel egy $3 \times 3$-as páros összehasonlítás mátrix vagy konzisztens vagy SP, kimondható az alábbi állítás:

1. Következmény. $H a \mathbf{A} \in \mathcal{P C} \mathcal{M}_{3}$, akkor $\mathbf{A}$ domináns jobb oldali sajátvektora Pareto-hatékony. Másképp fogalmazva a sajátvektor módszer $n=3$ esetén mindig hatékony megoldást ad.

$\mathrm{Az}$ 1. Következmény onnan is látható, hogy $n=3$ esetén a sajátvektor módszer ekvivalens a logaritmikus legkisebb négyzetek módszerével (lásd 
2.3.3. alfejezet), ez utóbbiról pedig Blanquero, Carrizosa és Conde [9] megmutatta, hogy minden esetben Pareto-hatékony.

\subsection{Két elemtôl eltekintve konzisztens páros összehasonlítás mátrixok}

Ebben az alfejezetben a [4] cikkünk eredményeit ismertetem.

Az elôző alfejezetben tárgyalt eredmény kiterjeszthetô. Ennek keretében az olyan páros összehasonlítás mátrixokat vizsgáljuk, melyek két elemtôl eltekintve konzisztensek (angolul double perturbed, röviden DP). Ilyen esetben feltehetô, hogy $n \geq 4$, mert egy $3 \times 3$-as páros összehasonlítás mátrix vagy konzisztens, vagy SP.

Két elemtól eltekintve konzisztens páros összehasonlítás mátrixok két módon lehetségesek, ennek megfelelően két esetet kell megkülönböztetni. Az első esetben a módosított elemek egy sorban vannak, a második esetben különbözô sorban. A bizonyításban szerepet játszó algebrai okok miatt a második esetet két alesetre (2.A és 2.B eset) kell bontani: az $n=4$ (2.A), illetve az $n \geq 5$ (2.B) esetre. Formálisan tehát bármely, legfeljebb két elemtôl eltekintve konzisztens páros összehasonlítás mátrix ekvivalens valamelyik, az alábbi definícióban adott alakkal:

10. Definíció. Egy páros összehasonlítás mátrix legfeljebb két elemtôl eltekintve konzisztens, ha alkalmas sor- és oszlopcserékkel az alábbi alakok egyikére hozható: 
1. eset $(n \geq 4)$ :

$$
\mathbf{P}_{\gamma, \delta}=\left(\begin{array}{cccccc}
1 & \boldsymbol{\delta} \boldsymbol{x}_{\mathbf{1}} & \boldsymbol{\gamma} \boldsymbol{x}_{\mathbf{2}} & x_{3} & \ldots & x_{n-1} \\
\mathbf{1} /\left(\boldsymbol{\delta} \boldsymbol{x}_{\mathbf{1}}\right) & 1 & x_{2} / x_{1} & x_{3} / x_{1} & \ldots & x_{n-1} / x_{1} \\
\mathbf{1} /\left(\boldsymbol{\gamma} \boldsymbol{x}_{\mathbf{2}}\right) & x_{1} / x_{2} & 1 & x_{3} / x_{2} & \ldots & x_{n-1} / x_{2} \\
1 / x_{3} & x_{1} / x_{3} & x_{2} / x_{3} & 1 & \ldots & x_{n-1} / x_{3} \\
\vdots & \vdots & \vdots & \vdots & \ddots & \vdots \\
1 / x_{n-1} & x_{1} / x_{n-1} & x_{2} / x_{n-1} & x_{3} / x_{n-1} & \ldots & 1
\end{array}\right)
$$

2.A eset $(n=4)$ :

$$
\mathbf{Q}_{\gamma, \delta}=\left(\begin{array}{cccc}
1 & \boldsymbol{\delta} \boldsymbol{x}_{\mathbf{1}} & x_{2} & x_{3} \\
\mathbf{1} /\left(\boldsymbol{\delta} \boldsymbol{x}_{\mathbf{1}}\right) & 1 & x_{2} / x_{1} & x_{3} / x_{1} \\
1 / x_{2} & x_{1} / x_{2} & 1 & \boldsymbol{\gamma} \boldsymbol{x}_{\mathbf{3}} / \boldsymbol{x}_{\mathbf{2}} \\
1 / x_{3} & x_{1} / x_{3} & \boldsymbol{x}_{\mathbf{2}} /\left(\boldsymbol{\gamma} \boldsymbol{x}_{\mathbf{3}}\right) & 1
\end{array}\right)
$$

2.B eset $(n \geq 5)$ :

$\mathbf{R}_{\gamma, \delta}=\left(\begin{array}{ccccccc}1 & \boldsymbol{\delta}_{\boldsymbol{1}} & x_{2} & x_{3} & x_{4} & \ldots & x_{n-1} \\ \mathbf{1} /\left(\boldsymbol{\delta} \boldsymbol{x}_{\mathbf{1}}\right) & 1 & x_{2} / x_{1} & x_{3} / x_{1} & x_{4} / x_{1} & \ldots & x_{n-1} / x_{1} \\ 1 / x_{2} & x_{1} / x_{2} & 1 & \boldsymbol{\gamma} \boldsymbol{x}_{\mathbf{3}} / \boldsymbol{x}_{\mathbf{2}} & x_{4} / x_{2} & \ldots & x_{n-1} / x_{2} \\ 1 / x_{3} & x_{1} / x_{3} & \boldsymbol{x}_{\mathbf{2}} /\left(\boldsymbol{\gamma} \boldsymbol{x}_{\mathbf{3}}\right) & 1 & x_{4} / x_{3} & \ldots & x_{n-1} / x_{3} \\ 1 / x_{4} & x_{1} / x_{4} & x_{2} / x_{4} & x_{3} / x_{4} & 1 & \ldots & x_{n-1} / x_{4} \\ \vdots & \vdots & \vdots & \vdots & \vdots & \ddots & \vdots \\ 1 / x_{n-1} & x_{1} / x_{n-1} & x_{2} / x_{n-1} & x_{3} / x_{n-1} & x_{4} / x_{n-1} & \ldots & 1\end{array}\right)$,

ahol $x_{1}, \ldots, x_{n-1}>0$ és $0<\delta, \gamma \neq 1$.

A 2.A és 2.B esetet összefoglalóan 2. esetnek nevezzük, amikor nem számít, hogy a mátrix $4 \times 4$-es vagy nagyobb.

Ha $\delta=1$ vagy $\gamma=1$, akkor a páros összehasonlítás mátrix SP. Ha $\delta=\gamma=1$, akkor pedig konzisztens. Továbbá az 1. esetben $n=4, \delta=\gamma$ mellett $\mathbf{P}_{\delta, \delta}$ szintén egy SP mátrix. Ez abból látható, hogy ha megszorozzuk az $(1,4)$ pozícióbeli $x_{3}$-mat $\delta$-val, akkor konzisztens mátrixot kapunk. 
Bozóki, Fülöp és Poesz [13] olyan páros összehasonlítás mátrixokat vizsgáltak, amelyek legfeljebb 3 elem megváltoztatásával konzisztenssé tehetőek, és ezekhez (a fenti 8. Definícióban lévôtôl különbözô) gráfokat rendeltek. A fenti esetek mindegyikének megfelel egy gráf: az 1. eset a [13, Fig. 6(b)] gráfnak, a 2. eset pedig a [13, Fig. 6(a)] gráfnak. Cook és Kress [22], illetve Brunelli és Fedrizzi [15] egy hasonló témát vizsgált, amelyben két páros összehasonlítás mátrixot hasonlítottak össze, amelyek csak egy elemben különböznek.

A 3. Tétel kiterjesztéseként a két elemtôl eltekintve konzisztens páros összehasonlítás mátrixokra is kimondhatjuk a hatékonysági tételt. A bizonyítás az olvashatóság kedvéért csak vázlatosan szerepel a fôszövegben, a részletek megtalálhatóak a [4] cikkünkben.

4. Tétel ([4, Theorem 3]). A két elemtól eltekintve konzisztens páros összehasonlítás mátrixok jobb oldali domináns sajátvektora Pareto-hatékony.

Bizonyítás. A 3. Tételhez hasonlóan a sajátvektor explicit képleteire van szükségünk. E célból - Farkas [34] SP esetre vonatkozó képleteinek bizonyításához hasonlóan - először a karakterisztikus polinomot írjuk fel. Az 1. esetre vonatkozó karakterisztikus polinomot és bizonyítását a [4, Proposition 1] állítás tartalmazza, a 2. (2.A és 2.B) esetét pedig a [4, Proposition 2] állítás.

A karakterisztikus polinom képletét felhasználva lehetôség nyílik a jobb oldali domináns sajátvektor képleteinek meghatározására, melyeket a [4, Proposition 3] állítás tartalmazza. Minden egyes eset képleteit (az SP esethez hasonlóan) több különbözô alakban fel lehet írni. A lemmák bizonyításakor derült ki, mikor melyik alak vezet célra.

A kapott sajátvektor formulákat felhasználva jónéhány egyenlőtlenség belátására nyílik lehetőség. Az egyenlôtlenségek a 8. Definícióban szereplô alulilletve felülbecsléseket, valamint ebból következően a gráf éleinek irányításait határozzák meg. Az egyenlótlenségeket 28 lemma tartalmazza [4, Lemma 
1a-3h]. A 15 oldalas bizonyítás a [4] cikk függelékében található, melynek nagyjából a fele a lemmák bizonyítása, ezért ennek teljes közlésével itt nem terhelem az Olvasót. Helyette illusztrációképpen szerepel itt az egyik lemma és bizonyítása.

A lemma ([4, Lemma 3f]) - mely a 2.B esetre vonatkozik - állítása a következô: Ha $\gamma>1, \delta<1 \Rightarrow w_{2}^{E M} / w_{4}^{E M}>x_{3} / x_{1}$, ha pedig $\gamma<1, \delta>1 \Rightarrow$ $w_{2}^{E M} / w_{4}^{E M}<x_{3} / x_{1}$.

A lemma állítása helyett a következô, erôsebb állítást fogjuk igazolni:

$$
\gamma \gtreqless \delta \Leftrightarrow w_{2}^{E M} / w_{4}^{E M} \gtreqless x_{3} / x_{1} .
$$

A [4, Formula (21)] sajátvektor képletet használjuk ehhez a bizonyításhoz, mely szerint $w_{2}=\frac{x_{4}}{x_{1}} \lambda\left(\gamma^{2}-2 \gamma+\lambda^{2} \gamma+1\right)(1+\delta \lambda-\delta)$ és $w_{4}=\frac{x_{4}}{x_{3}} \lambda\left(\delta \lambda^{2}+\right.$ $\left.\lambda^{3} \delta \gamma-\delta \gamma \lambda^{2}-2 \lambda \delta \gamma-2 \delta+2 \delta \gamma-\gamma+1+\lambda \gamma+\delta^{2}+\delta^{2} \lambda \gamma-\delta^{2} \gamma\right)$. Így a fenti egyenlőtlenség átírható:

$$
\begin{aligned}
& \frac{x_{4}}{x_{1}} \lambda\left(\gamma^{2}-2 \gamma+\lambda^{2} \gamma+1\right)(1+\delta \lambda-\delta) \\
\gtreqless & \frac{x_{3}}{x_{1}} \frac{x_{4}}{x_{3}} \lambda\left(\delta \lambda^{2}+\lambda^{3} \delta \gamma-\delta \gamma \lambda^{2}-2 \lambda \delta \gamma-2 \delta+2 \delta \gamma-\gamma+1+\lambda \gamma+\delta^{2}+\delta^{2} \lambda \gamma-\delta^{2} \gamma\right),
\end{aligned}
$$

mely ekvivalens a következôvel:

$$
\begin{gathered}
\gamma^{2}+\lambda \gamma^{2} \delta-\gamma^{2} \delta-2 \gamma-2 \lambda \gamma \delta+2 \gamma \delta+\lambda^{2} \gamma+\lambda^{3} \gamma \delta-\lambda^{2} \gamma \delta+1+\lambda \delta-\delta \\
\gtreqless \lambda^{2} \delta+\lambda^{3} \gamma \delta-\lambda^{2} \gamma \delta-2 \lambda \gamma \delta-2 \delta+2 \gamma \delta-\gamma+1+\lambda \gamma+\delta^{2}+\lambda \gamma \delta^{2}-\gamma \delta^{2} .
\end{gathered}
$$

További ekvivalens átalakításokkal kapjuk:

$$
\begin{gathered}
\lambda^{2} \gamma-\lambda^{2} \delta+\lambda \delta-\lambda \gamma+\lambda \gamma^{2} \delta-\lambda \gamma \delta^{2}+\gamma^{2}-\delta^{2}+\gamma \delta^{2}-\gamma^{2} \delta+2 \delta-2 \gamma+\gamma-\delta \gtreqless 0 \\
\lambda^{2}(\gamma-\delta)+\lambda(\delta-\gamma)+\lambda \gamma \delta(\gamma-\delta)+(\gamma+\delta)(\gamma-\delta)+\gamma \delta(\delta-\gamma)+2(\delta-\gamma)+(\gamma-\delta) \gtreqless 0 \\
(\gamma-\delta)\left(\lambda^{2}-\lambda+\lambda \gamma \delta+\gamma+\delta-\gamma \delta-1\right) \gtreqless 0 \\
(\gamma-\delta)\left(\lambda^{2}-2 \lambda+\lambda \gamma \delta-\gamma \delta+\lambda-1+\gamma+\delta\right) \gtreqless 0 \\
(\gamma-\delta)(\lambda(\lambda-2)+\gamma \delta(\lambda-1)+(\lambda-1)+\gamma+\delta) \gtreqless 0 .
\end{gathered}
$$


A bal oldalon a második tényezô mindig pozitív, mivel $\lambda>n \geq 5$ és $\gamma, \delta>0$. Ezzel a lemmát beláttuk.

A többi 27 lemma is hasonlóan bizonyítható, melyekhez különböző sajátvektor képleteket célszerú alkalmazni. A lemmákból származó egyenlőtlenségek lehetôvé teszik, hogy a 8. Tételbeli irányított gráf egyes éleinek irányítását meghatározzuk. Mivel az erôs összefüggôség (szükséges és) elégséges feltétel, ha egy erôsen összefüggő részgráfot találunk, mely minden csúcsot tartalmaz, akkor abból már következik az egész gráf erôs összefüggôsége és így a sajátvektor hatékonysága is.

A különbözô esetek irányított gráfjai a 4.3-4.5 ábrákon láthatóak. Az egyes gráfok a paraméterek függvényében rajzolhatóak fel, amit az ábrán a gráf megfelelő síkrészben való szerepeltetésével szemléltetünk: például a 4.3 ábrán a bal felsô sarokban látható gráf esetén $\delta<1$ és $\gamma>1$. Az egyes éleken szereplô jelölések azt mondják meg, hogy az él irányítását melyik lemmából lehet meghatározni. A szaggatott élek irányítását nem vizsgáltuk, mivel ezek meghatározása nélkül is bizonyítható a hatékonyság. Az 1. és a 2.B esetben a gráfban található egy $i$-vel jelzett csúcs. Ez egy teljes részgráfot jelöl $(n-3$ pontút az elsố esetben és $n-4$ pontút a 2 .B esetben), melyen belül bármely két pont között a [4, Lemma 1j] és a [4, Lemma 3h] lemmák miatt oda-vissza vezet él, mely természetesen egy erôsen összefüggő részgráf. Az említett lemmák a módosított elemek által érintetlen sorok és oszlopok eseteit fedik le, ez esetben pedig a közelítés tökéletes. Továbbá az 1. esetben bármely rögzített $j \leq 3$-ra az $i$ és $j$ csúcs közötti élek irányítása ugyanaz bármilyen $i \geq$ 4-re (lásd a [4, Lemma 1e, 1f, 1h, 1i] lemmákat). Hasonlóan bármely rögzített $j \leq 4$-re az $i$ és $j$ csúcs közötti élek irányítása ugyanaz bármilyen $i \geq 5$-re a 2.B esetben (lásd a [4, Lemma 3c, 3d, 3e] lemmákat). Következésképp a teljes részgráf összehúzható egyetlen ponttá az erôs összefüggôség vizsgálatakor.

Az 1., 2.A és 2.B esethez a 4.3, 4.4 és 4.5 ábra tartozik rendre. Az erôs összefüggőség igazolásához elegendô a redukált gráfban (melyben az $i$ pontba húztuk össze a teljes részgráfot) találni egy irányított Hamilton-kört. 
Az irányított Hamilton-körök a következôek:

4.3. ábra. A domináns jobb oldali sajátvektorhoz tartozó irányított gráf az 1. esetben erôsen összefüggő a nem vizsgált szaggatott élek irányításától függetlenül

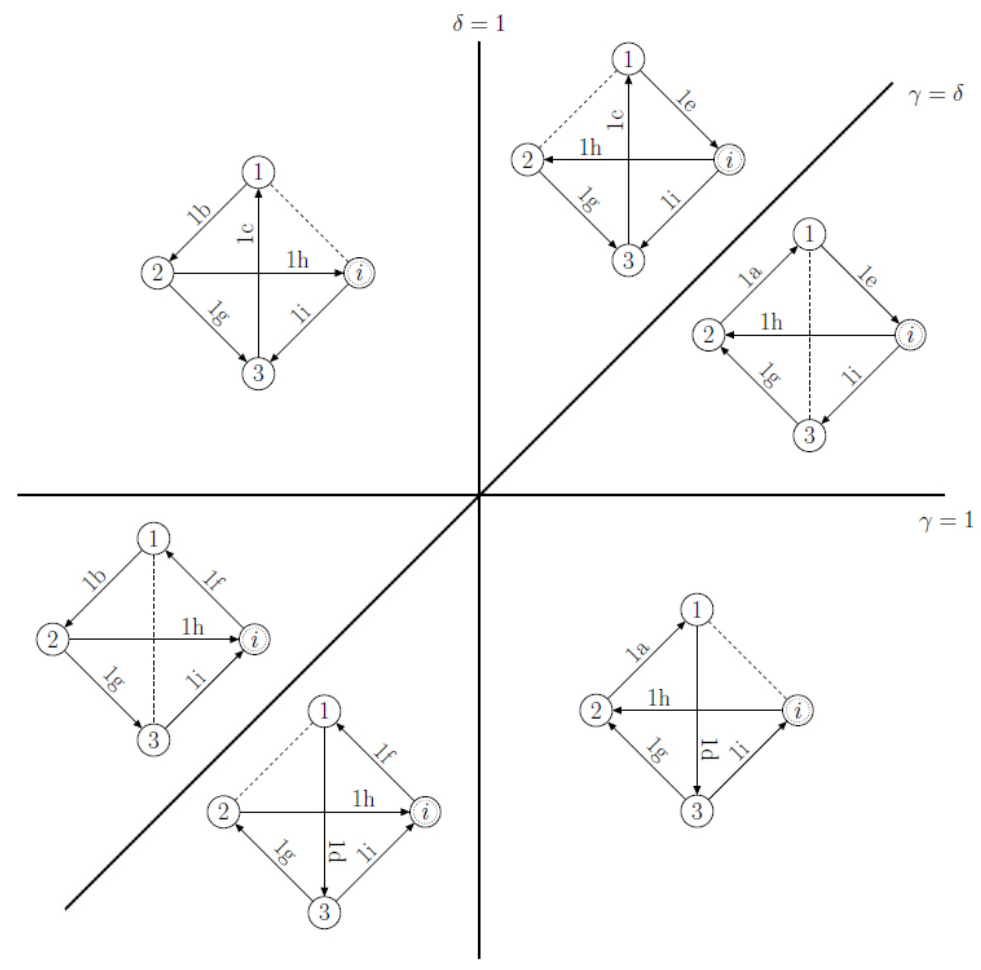

1. eset:

$$
\begin{aligned}
& \delta>1, \gamma>\delta: 1 \rightarrow i \rightarrow 2 \rightarrow 3 \rightarrow 1 \\
& \gamma>1, \gamma<\delta: 1 \rightarrow i \rightarrow 3 \rightarrow 2 \rightarrow 1 \\
& \delta>1, \gamma<1: 1 \rightarrow 3 \rightarrow i \rightarrow 2 \rightarrow 1 \\
& \delta<1, \gamma<\delta: 1 \rightarrow 3 \rightarrow 2 \rightarrow i \rightarrow 1 \\
& \gamma<1, \gamma>\delta: 1 \rightarrow 2 \rightarrow 3 \rightarrow i \rightarrow 1 \\
& \delta<1, \gamma>1: 1 \rightarrow 2 \rightarrow i \rightarrow 3 \rightarrow 1
\end{aligned}
$$


4.4. ábra. A domináns jobb oldali sajátvektorhoz tartozó irányított gráf a 2.A esetben erôsen összefüggố a nem vizsgált szaggatott élek irányításától függetlenül

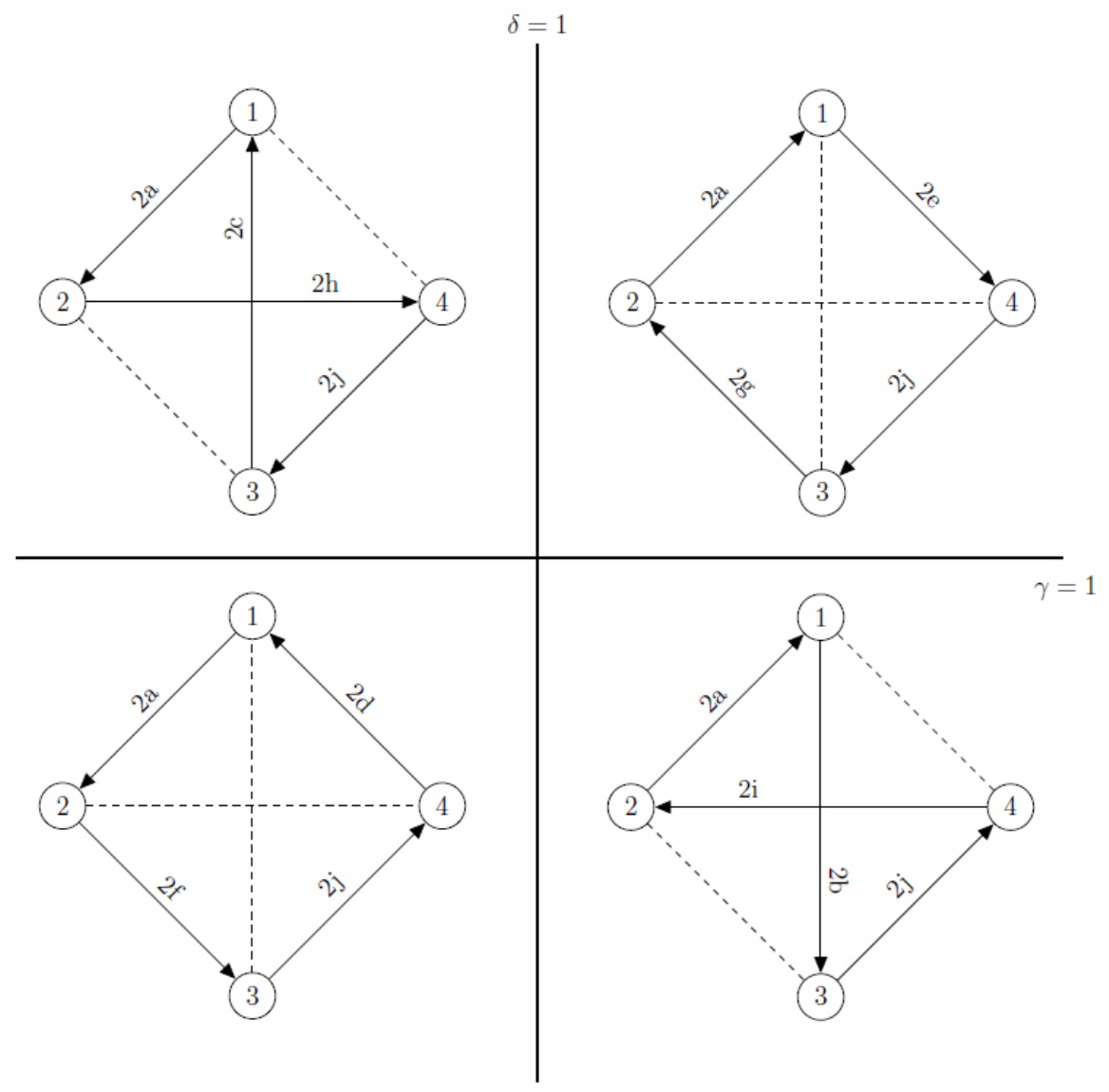

2.A eset:

$$
\begin{aligned}
& \delta>1, \gamma>1: 1 \rightarrow 4 \rightarrow 3 \rightarrow 2 \rightarrow 1 \\
& \delta>1, \gamma<1: 1 \rightarrow 3 \rightarrow 4 \rightarrow 2 \rightarrow 1 \\
& \delta<1, \gamma<1: 1 \rightarrow 2 \rightarrow 3 \rightarrow 4 \rightarrow 1 \\
& \delta<1, \gamma>1: 1 \rightarrow 2 \rightarrow 4 \rightarrow 3 \rightarrow 1
\end{aligned}
$$


4.5. ábra. A domináns jobb oldali sajátvektorhoz tartozó irányított gráf a 2.B esetben erôsen összefüggô a nem vizsgált szaggatott élek irányításától függetlenül

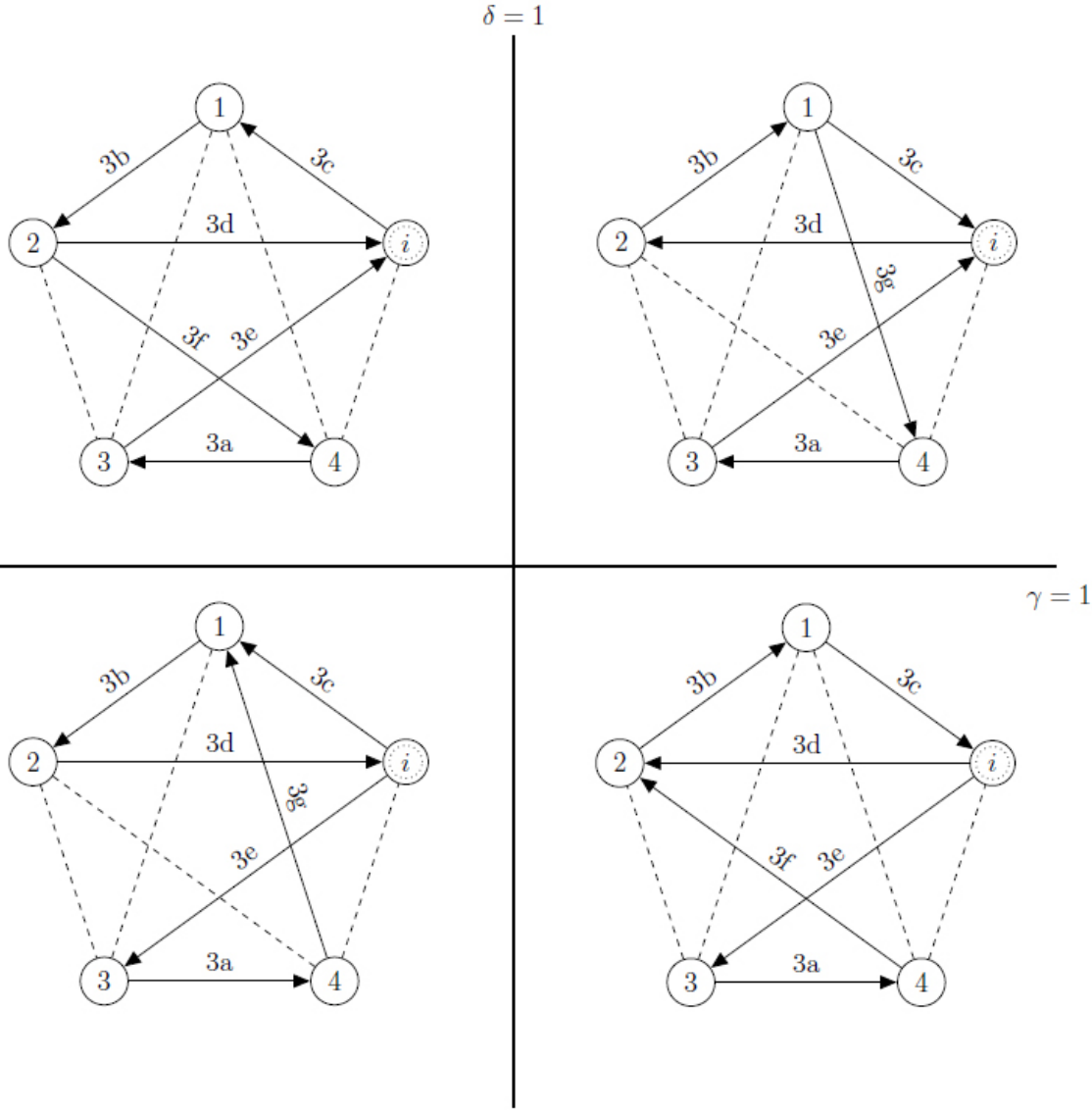

2.B eset:

$$
\begin{aligned}
& \delta>1, \gamma>1: 1 \rightarrow 4 \rightarrow 3 \rightarrow i \rightarrow 2 \rightarrow 1 \\
& \delta>1, \gamma<1: 1 \rightarrow i \rightarrow 3 \rightarrow 4 \rightarrow 2 \rightarrow 1 \\
& \delta<1, \gamma<1: 1 \rightarrow 2 \rightarrow i \rightarrow 3 \rightarrow 4 \rightarrow 1 \\
& \delta<1, \gamma>1: 1 \rightarrow 2 \rightarrow 4 \rightarrow 3 \rightarrow i \rightarrow 1
\end{aligned}
$$


Mivel az összes eset összes lehetséges paraméter értékére felrajzolható gráfban találtunk irányított Hamilton-kört, ezért a hatékonyságot minden, két elemtól eltekintve konzisztens esetben beláttuk.

A 2. Állítást, valamint a 3. és 4. Tételeket összefoglalva a következô mondható ki:

2. Következmény. A legfeljebb két elemtól eltekintve konzisztens páros összehasonlitás mátrixok esetén a jobb oldali domináns sajátvektor hatékony.

Az eddigi eredmények alapján felmerülhet, hogy miért ne folytathatnánk a hatékonyság vizsgálatát a három, illetve több elemtôl eltekintve konzisztens páros összehasonlítás mátrixok esetén is. Több elem megváltoztatása esetén azonban a hatékonyságot ilyen általánosan biztosan nem lehet bizonyítani. Már a $4 \times 4$-es esetben is van ellenpélda: emlékezzünk vissza az 1. példára. Minden $4 \times 4$-es páros összehasonlítás mátrix, amely nem legfeljebb két elemtôl eltekintve konzisztens, pontosan három elemtól eltekintve konzisztens. Így tehát még ha speciális, három elemtôl eltekintve konzisztens mátrixokra meg is lehetne mutatni (például reményt keltônek túnik az az eset, amikor az összes módosított elem egy sorban van), az összesre ez biztosan lehetetlen. Ami még tovább rontja a helyzetet, egy három elemtôl eltekintve konzisztens mátrix 5 különböző esettel lehet ekvivalens (lásd [13, Fig. 7]), amiket a DP esethez hasonlóan akár további alesetekre is szükséges lehet tovább bontani. A fenti okok miatt a két elemtől eltekintve konzisztens esettel az ilyen irányú vizsgálódások tulajdonképpen lezárhatóak. 


\section{5. fejezet}

\section{A sajátvektor számítása ciklikus koordináták módszerével}

A 2.3.1. alfejezetben tárgyalt sajátvektor módszer és annak 2.5.2. alfejezetben tárgyalt kiterjesztése a nem teljesen kitöltött páros összehasonlítás mátrixok esetére az egyik legfontosabb súlyvektor számítási módszer. Először a nem teljesen kitöltött esetben történő optimális kitöltéssel kapcsolatos saját eredmény [2] kerül ismertetésre, majd egy általános módszer domináns sajátérték és sajátvektor számításra [5]. Mindkét esetben a ciklikus koordináták módszerét [60][253-254. oldal] alkalmazzuk.

A ciklikus koordináták módszerének lényege, hogy egy többváltozós optimalizálási feladatban egyszerre mindig csak egy változót tekintünk ténylegesen változónak, a többi változó az elôzô lépésben számolt értéken van rögzítve. Annak az elemnek, amelyik ténylegesen változik, az új értéke az a szám lesz, ahol az optimalizálási feladat szerinti (a többi elem változatlansága melletti) optimuma felvétetik. Azt, hogy melyik változót tekintjük egy adott lépésben ténylegesen változónak, ciklikusan változtatjuk, azaz először az elsôt, majd a másodikat stb., majd amikor az utolsó változón is túl vagyunk, visszaugrunk az elsôre és ugyanígy folytatjuk, amíg el nem érjük a leállási kritériumot. Az, hogy mi a leállási kritérium, a feladattól függ. 
A nem teljesen kitöltött páros összehasonlítás mátrixok és a sajátvektor módszer témakörében megemlítendő Fülöp eredménye [39]. Ez az eljárás hasonló alapokon nyugszik, mint az 5.2. alfejezetben bemutatott algoritmus, de nem ciklikus koordinátákkal dolgozik.

\subsection{Optimális kitöltés Newton-módszerrel}

Ebben az alfejezetben a [2] cikkem eredményeit tárgyaljuk, melyek alapjait az Eötvös Loránd Tudományegyetemen 2010-ben készült diplomamunkámban [1] dolgoztam ki.

Legyen A egy $n \times n$-es nem teljesen kitöltött páros összehasonlítás mátrix, $d$ hiányzó elemmel. Tekintsük az 5. Definícióbeli kitöltését az $x_{1}, \ldots, x_{d}$ változókkal. A sajátvektor módszer 2.5.2. alfejezetbeli általánosítását szeretnénk alkalmazni a nem teljesen kitöltött esetre, a (2.23) feladat szerint. Tegyük fel, hogy az A-hoz tartozó 2.5.1. alfejezetbeli 6. Definíció szerinti $G_{\mathbf{A}}(V, E)$ gráf összefüggô, mivel a 2.5.2. alfejezetben említettek szerint a sajátértékminimalizálási feladatnak pontosan akkor létezik egyértelmú megoldása, ha $G_{\mathbf{A}}(V, E)$ összefüggó [12].

Célunk tehát az $\mathbf{A}$ mátrix domináns sajátértékét, $\lambda_{\max }\left(\mathbf{A}\left(x_{1}, \ldots, x_{d}\right)\right)$-t minimalizálni $x_{1}, \ldots, x_{d}$-ben, azaz a (2.23) optimalizálási feladatot megoldani, mivel a 2.5.2. alfejezetben leírt módon ez adja az $\mathbf{A}$ mátrix optimális kitöltését. Ez egy többváltozós optimalizálási feladat, melyet elôször a ciklikus koordináták módszerét alkalmazva oldunk meg, majd az 5.1.2. alfejezetben többváltozós Newton-módszerrel.

\subsubsection{Egyváltozós Newton-módszer}

A ciklikus koordináták módszerénél mindig kulcskérdés, hogy az egyes lépésekben az egyváltozós optimumhelyet és -értéket hogyan számoljuk ki. A sajátvektor módszer esetén Bozóki, Fülöp és Rónyai a Matlab programcso- 
magban található fminbnd nevú általános numerikus optimalizáló módszert használták [12].

A most bemutatott esetben az egyváltozós optimalizálási feladatokat Newton-módszerrel fogjuk megoldani. A Newton-módszer egy iteratív módszer. Az r-edik iterációban egy általános $f(x)$ függvényre a szélsőérték keresô algoritmus alapvető formája a következő:

$$
x^{(r+1)}=x^{(r)}-\frac{f^{\prime}\left(x^{(r)}\right)}{f^{\prime \prime}\left(x^{(r)}\right)},
$$

ahol $x^{(r)}$ az $x$ változó $r$-edik iterációban számolt értéke. Ennek a kiszámításához szükség van az $f$ függvény első és második deriváltjára, ami a mi esetünkben a domináns sajátértéknek, $\lambda_{\max }$-nak a mátrix hiányzó elemei szerinti deriváltjai. Sajnos azonban a $\lambda_{\max }$ optimalizálása közvetlenül a hiányzó elemekben egy nem konvex feladat [12].

Annak érdekében, hogy garantálható legyen az egyértelmú globális minimumhoz való konvergencia, a feladatot át kell skáláznunk olyan módon, hogy konvex optimalizálási feladatot kapjunk. Bozóki, Fülöp és Rónyai [12] ötlete alapján legyen $x_{i}=e^{t_{i}}, i=1, \ldots, d$. Így az 5. Definíció szerinti $\mathbf{A}(\mathbf{x})=\mathbf{A}\left(x_{1}, \ldots, x_{d}\right)$ mátrixot az alábbi formára hozzuk:

$$
\mathbf{B}\left(t_{1}, \ldots, t_{d}\right)=\mathbf{B}(\mathbf{t})=\left(\begin{array}{ccccc}
1 & a_{12} & e^{t_{1}} & \ldots & a_{1 n} \\
1 / a_{12} & 1 & a_{23} & \ldots & e^{t_{d}} \\
e^{-t_{1}} & 1 / a_{23} & 1 & \ldots & a_{3 n} \\
\vdots & \vdots & \vdots & \ddots & \vdots \\
1 / a_{1 n} & e^{-t_{d}} & 1 / a_{3 n} & \ldots & 1
\end{array}\right)
$$

ahol $t_{i} \in \mathbb{R}, i=1, \ldots, d$, és $\mathbf{B}(\mathbf{t})=\mathbf{A}(\mathbf{x})$. A domináns sajátérték, $\lambda_{\max }(\mathbf{B}(\mathbf{t}))$ már konvex függvénye t-nek [12].

Harker [43] jóvoltából ismertek a domináns sajátértéknek a mátrix elemei szerinti elsô és második deriváltjai, és ezek csak a mátrixelem $(i, j)$ pozíciójától függnek. Ezek a deriváltak azonban az eredeti mátrixelemekre, azaz az 
$x_{i}, i=1, \ldots, d$-re vonatkoznak, és nem $t_{i}$-re. Ahhoz, hogy a $t_{i}$ szerint vett deriváltakat megkapjuk, magukat a deriváltakat is át kell skálázni.

Jelöljük $L(t)=\lambda_{\max }\left(e^{t}\right)$-vel a domináns sajátérték egy tetszôleges $t_{i}$ szerint vett deriváltját. Ekkor a [2] cikkben található levezetés alapján az elsô derivált

$$
\frac{\partial L(t)}{\partial t}=\frac{\partial \lambda_{\max }(x)}{\partial x} \cdot e^{t}
$$

ahol $\frac{\partial \lambda_{\max }(x)}{\partial x}$ Harker cikkébôl [43] ismert, és csak $x$ mátrixbeli pozíciójától függ.

Hasonlóan, a második derivált a [2]-beli levezetés alapján

$$
\frac{\partial^{2} L(t)}{(\partial t)^{2}}=\frac{\partial^{2} \lambda_{\max }(x)}{(\partial x)^{2}} \cdot e^{2 t}+\frac{\partial \lambda_{\max }(x)}{\partial x} \cdot e^{t}
$$

ahol $\frac{\partial^{2} \lambda_{\max }(x)}{(\partial x)^{2}}$ szintén ismert [43]-ból, és csak $x$ pozíciójától függ. Jegyezzük meg, hogy az $x$ változók az 5 . Definíció szerint mind a felsô háromszögben vannak.

Az elóbbiek alapján ebben az esetben az egyváltozós Newton-módszer $r$-edik lépése a következô alakban írható fel:

$$
t^{(r+1)}=t^{(r)}-\frac{L^{\prime}\left(t^{(r)}\right)}{L^{\prime \prime}\left(t^{(r)}\right)}=t^{(r)}-\frac{\frac{\partial \lambda_{\max }(x)}{\partial x}\left(x^{(r)}\right)}{\frac{\partial^{2} \lambda_{\max }(x)}{(\partial x)^{2}}\left(x^{(r)}\right) \cdot e^{t^{(r)}}+\frac{\partial \lambda_{\max }(x)}{\partial x}\left(x^{(r)}\right)},
$$

ahol az $(r)$ felső indexek az elôzô lépésben számolt értékeket jelentik. Ezzel az (5.2) képlet jobb oldalán minden érték ismert.

Így az egyváltozós Newton-iteráció egy teljes lépése az alábbiakból áll:

1. $t^{(r)}=\ln x^{(r)}$,

2. Alkalmazzuk (5.2)-t,

3. $x^{(r+1)}=e^{t^{(r+1)}}, 1 / x^{(r+1)}=e^{-t^{(r+1)}}$.

Kiemelendő, hogy itt két egymásba ágyazott ciklusról van szó. A külső iteráció a ciklikus koordináták módszere, amely a változókon halad körbe, a 
belsô pedig a Newton-módszer, amely egyszerre egy, a ciklikus koordináták által az adott lépésben kijelölt változó szerint optimalizál. Miután elértük a megállási kritériumot, az $\mathrm{x}$ vektor megadja az optimális kitöltést, melyből már számolható a hozzá tartozó domináns sajátvektor.

A megállási kritérium az, hogy az $x_{i}$ értékek már nem változnak „sokat”. Formálisan az algoritmus a $k$-adik lépésben áll meg, ha $k$ a legkisebb olyan egész, amire

$$
\max _{i=1,2, \ldots, d}\left|x_{i}^{(k)}-x_{i}^{(k-1)}\right|<T
$$

ahol $T$ a toleranciaküszöb. A megállási kritérium az x-re van meghatározva, nem t-re, mert a t-re számolt apró különbség is nagy különbséget eredményezhet $\mathbf{x}$-ben az exponenciális transzformáció miatt.

A $T$ küszöbre a $T=10^{-4}$ értéket használtam a vizsgálatokban és példákban. Az egyik oka enne az, hogy a [12] cikkben is ugyanezt használták a szerzók. A másik pedig, hogy a tapasztalatok alapján ez egy jó kompromisszumnak tûnik a futási idő és a pontosság között.

Egy további tisztázandó kérdés a kezdőértékek beállítása. Egy egyszerû lehetôség a kezdőértékekre az, ha minden változót egyrôl indítunk, azaz $x_{i}^{(0)}=1, i=1, \ldots, d[12]$. Egy másik kézenfekvô lehetőség a változók kezdőértékeit a logaritmikus legkisebb négyzetek módszeréból meghatározni a 2.5.2. alfejezetben leírt módon, mely egy lineáris egyenletrendszer megoldásával kapható. Az így nyert $\mathbf{w}^{I L L S M}$ súlyvektor megfelelő elemeinek arányaiból indíthatjuk az iterációt, azaz ha $x_{i}$ a $(p, q)$ pozícióban van, akkor $x_{i}^{(0)}=w_{p}^{I L L S M} / w_{q}^{I L L S M}$. A logaritmikus legkisebb négyzetek által ilyen módon adott értékek tipikusan közel vannak a sajátvektor módszer által adott értékekhez [47], így a célhoz közeli pontból indítva csökkenthetjük az iterációk számát. 


\subsubsection{Többváltozós Newton-módszer}

A ciklikus koordináták alkalmazása helyett a többváltozós Newton-módszert használva egyszerre az összes változóban optimalizálhatunk. Legyen $L(\mathbf{t})=$ $\lambda_{\max }\left(e^{t_{1}}, \ldots, e^{t_{d}}\right)$, melyet minimalizálni szeretnénk. A többváltozós Newtonmódszer ebben az esetben a

$$
\mathbf{t}^{(r+1)}=\mathbf{t}^{(r)}-\gamma\left[H L\left(\mathbf{t}^{(r)}\right)\right]^{-1} \nabla L\left(\mathbf{t}^{(r)}\right)
$$

formát ölti, ahol $H L(\mathbf{t})$ az $L(\mathbf{t})$ Hesse-mátrixa, $\nabla L(\mathbf{t})$ a gradiens vektora, $\gamma$ pedig egy, a Newton-módszernél szokásos lépésköz paraméter. Ezt a lépésköz paramétert az egyváltozós módszernél is használhatjuk, de a numerikus teszteknél nem alkalmaztuk [2].

A gradiens vektor és a Hesse-mátrix minden eleme ismert Harker képleteiból [43]. Az átskálázást is meghatároztuk az összes elsố deriváltra, azaz a gradiens vektor elemeire, valamint ugyanazon elem szerinti kétszeres deriváltakra, azaz a Hesse-mátrix diagonálisára. Meg kell azonban határoznunk az átskálázott deriváltakat a két különbözô elem szerinti második deriváltakra is. A [2]-beli levezetés szerint

$$
\frac{\partial^{2} L(\mathbf{t})}{\partial t_{i} \partial t_{j}}=\frac{\partial^{2} \lambda_{\max }(\mathbf{x})}{\partial x_{i} \partial x_{j}} \cdot e^{t_{i}+t_{j}}+\frac{\partial \lambda_{\max }(\mathbf{x})}{\partial x_{i}} \cdot e^{t_{i}} \cdot \chi_{\{i=j\}}
$$

ahol

$$
\chi_{\{i=j\}}=\left\{\begin{array}{ll}
1 & \text { ha } i=j \\
0 & \text { ha } i \neq j
\end{array} .\right.
$$

Vegyük észre, hogy (5.4) speciális esetként tartalmazza (5.1)-et, ha ugyanazon elem szerint deriválunk kétszer $(i=j)$.

Az indulóértékek és a megállási kritérium ugyanaz az egy- és többváltozós esetben. A [2] cikkben egy numerikus példán is bemutattam mindkét algoritmust. 


\subsection{Pozitív mátrixok domináns sajátvektora cik- likus koordinátákkal}

Ebben a fejezetben az [5] cikkben leírt eredményeket tárgyaljuk. Az [5] cikkben egy iteratív algoritmust adtunk pozitív mátrixok domináns sajátértékének és sajátvektorának kiszámítására. Ez az eljárás ugyan igen általános keretek között is múködik, de egyik alkalmazása a sajátvektor módszer számolása páros összehasonlítás mátrixok esetén. A közvetlen alkalmazhatóság oka, hogy az 1. Definíció szerint egy páros összehasonlítás mátrix mindenképpen pozitív, a 2.3.1. alfejezetben leírtak szerint pedig a sajátvektor módszer esetén a súlyvektor a domináns sajátvektor lesz.

11. Definíció. Egy A négyzetes mátrix irreducibilis, ha nem hozható sorok és oszlopok egyszerre történő cseréivel a következó blokk felső háromszög alakra:

$$
\left(\begin{array}{cc}
\text { B } & C \\
0 & D
\end{array}\right),
$$

ahol $\mathbf{B}$ és $\mathbf{D}$ nem 0 méretủ négyzetes mátrixok.

A definícióból adódóan, a szigorú pozitivitás miatt, minden páros összehasonlítás mátrix irreducibilis.

Mint korábban is, jelölje $\lambda_{\max }=\lambda_{\max }(\mathbf{A})$ a domináns sajátértéket. Ekkor az alábbi összefüggés teljesül:

5. Tétel (Collatz-Wielandt). Legyen $\mathbf{A} \geq 0$ egy irreducibilis $n \times n$-es mátrix.

$$
\begin{aligned}
\lambda_{\max } & =\max _{\mathbf{w}>0} \min _{i=1, \ldots, n} \frac{(\mathbf{A w})_{i}}{w_{i}}= \\
& =\min _{\mathbf{w}>0} \max _{i=1, \ldots, n} \frac{(\mathbf{A w})_{i}}{w_{i}} .
\end{aligned}
$$

Megjegyzendő, hogy ugyan a Collatz-Wielandt formulát alkalmazhatjuk páros összehasonlítás mátrixokra is, azonban kizárólag a kitöltött esetre tudjuk ezt közvetlenül megtenni. Innentôl feltesszük, hogy $\mathbf{A}>0$, tehát szigorúan pozitív mátrixról van szó. 
Az algoritmus az (5.6) formulát használja a $\lambda_{\max }$ közelítésére, azonban ez a választás önkényes: az algoritmus könnyen átalakítható úgy, hogy az (5.5) összefüggést használja. Késóbb azonban mindkét alakot felhasználjuk a megállási kritérium meghatározásához.

Ebben az esetben is a ciklikus koordináták módszerét alkalmazzuk. A változóink ezúttal a domináns sajátvektor, w elemei: $w_{1}, \ldots, w_{n}$. A ciklikus koordináták módszere, a fejezet bevezetôjében leírtak szerint minden lépésben csak egy változót tekint ténylegesen változónak. Jelölje ennek a változónak az indexét $k$, így minden lépésben $w_{k}$ lesz az aktuális változónk, míg a többi változó értéke ideiglenesen azok elôzô lépésben számolt értékein van rögzítve.

A fentiek alapján (5.6) szerint minden lépésben $w_{k}$ azon értékét keressük, amire teljesül, hogy

$$
w_{k}=\underset{w_{k}}{\arg \min } \max _{i=1, \ldots, n} \frac{(\mathbf{A w})_{i}}{w_{i}} .
$$

Mivel a többi, $w_{j}, j \neq k$ érték fix, ezért az (5.7) kifejezés minden $i$-re csupán $w_{k}$-tól függ. Így bevezethetjük a következő jelölést. Legyen

$$
f_{i}\left(w_{k}\right)=\frac{(\mathbf{A w})_{i}}{w_{i}}, \quad i=1, \ldots, n .
$$

Amit keresünk tehát egy lépésben, az az a $w_{k}>0$ érték, amelyre

$$
w_{k}=\underset{w_{k}}{\arg \min } \max _{i=1, \ldots, n} f_{i}\left(w_{k}\right)
$$

azaz ahol az $f_{i}$ függvények felsô burkolójának a minimumpontja van. Az $f_{i}\left(w_{k}\right)$ függvényérték pedig a $\lambda_{\max }$ közelítése (felsô korlátja) lesz.

Mivel

$$
f_{i}\left(w_{k}\right)=\frac{(\mathbf{A} \mathbf{w})_{i}}{w_{i}}=\sum_{j=1}^{n} \frac{a_{i j} w_{j}}{w_{i}}, \quad i=1, \ldots, n,
$$

ezért a vizsgált $f_{i}$ függvények $i \neq k$-ra lineáris függvények, hiszen a változó, $w_{k}$, csak az $n$ tagú összeg számlálójában szerepel. Hasonlóan, $i=k$-ra $f_{k}\left(w_{k}\right)$ egy hiperbolikus függvény, mert $w_{k}$ a nevezôben szerepel, illetve egyszer a számlálóban is, de ez kiegyszerúsödik. 
Az $f_{i}$ függvények tehát felírhatóak a következô alakban:

$$
f_{i}\left(w_{k}\right)=\frac{(\mathbf{A w})_{i}}{w_{i}}=a_{i} w_{k}+b_{i}, \quad i \neq k
$$

valamilyen $a_{i}>0$ és $b_{i}>0$ konstansokkal. Hasonlóan, $i=k$-ra

$$
f_{k}\left(w_{k}\right)=\frac{(\mathbf{A} \mathbf{w})_{k}}{w_{k}}=\frac{c}{w_{k}}+d
$$

valamilyen $c, d>0$ konstansokkal. A konstansok egzakt alakja meghatározható az (5.9) formula alapján:

$$
\begin{aligned}
a_{i} & =\frac{a_{i k}}{w_{i}} \\
b_{i} & =\sum_{j \neq k} \frac{a_{i j} w_{j}}{w_{i}} \\
c & =\sum_{j \neq k} a_{k j} w_{j} \\
d & =a_{k k} .
\end{aligned}
$$

A következô állítás a felsô burkoló minimumpontjának meghatározásához visz közelebb:

3. Állítás. $A z(5.7)$ összefüggést teljesítô $w_{k}-r a$

$$
f_{i}\left(w_{k}\right)=f_{k}\left(w_{k}\right)
$$

valamilyen $i \neq k$-ra.

Bizonyítás. Mivel $a_{i}, b_{i}>0 \forall i \neq k$-ra az (5.10) képletben, ezért az $f_{i}\left(w_{k}\right)$, $i \neq k$ lineáris függvények szigorúan monoton növôk, így a felsố burkolójuk is szigorúan monoton növô. Hasonlóan, mivel $c, d>0$ az (5.11) képletben, és mert $w_{k}>0$, az $f_{k}\left(w_{k}\right)$ hiperbolikus függvény szigorúan monoton csökkenő.

Tekintsük a következô, elemi úton adódó határértékeket:

$$
\lim _{w_{k} \rightarrow 0+} f_{k}\left(w_{k}\right)=\infty
$$




\subsection{DOMINÁNS SAJÁTVEKTOR CIKLIKUS KOORDINÁTÁKKAL 101}

$$
\begin{aligned}
& \lim _{w_{k} \rightarrow \infty} f_{k}\left(w_{k}\right)=d<\infty \\
& \lim _{w_{k} \rightarrow \infty} \max _{i \neq k} f_{i}\left(w_{k}\right)=\infty,
\end{aligned}
$$

továbbá

$$
\max _{i \neq k} f_{i}(0)<\infty
$$

is teljesül.

Ezek alapján, és mivel az $f_{i}\left(w_{k}\right), i=1, \ldots, n$ függvények folytonos, szigorúan monoton függvények, az $f_{i}\left(w_{k}\right), i \neq k$ függvények felsô burkolója és az $f_{k}\left(w_{k}\right)$ egyetlen pontban metszik egymást. Így az elóbbi monotonitási tulajdonságok szerint a $\max _{i=1, \ldots, n} f_{i}\left(w_{k}\right)$ minimumpontja ebben a metszéspontban van, ahol $\max _{i \neq k} f_{i}\left(w_{k}\right)=f_{k}\left(w_{k}\right)$. Mivel $\max _{i \neq k} f_{i}\left(w_{k}\right)$ véges sok lineáris függvény felső burkolója, ezért létezik egy $i \neq k$, amire $f_{i}\left(w_{k}\right)=f_{k}\left(w_{k}\right)$.

A 3. Állításból következik, hogy elegendő csak az $f_{k}$ függvény metszéspontjait kiszámolni minden $f_{i}, i \neq k$ függvénnyel. Az $f_{k}$ szigorúan monoton csökkenése miatt, az a $w_{k}>0$, amelyik eleget tesz az (5.7) feltételnek, az a legkisebb $w_{k}$ lesz, amelyik eleget tesz (5.16)-nak. A következô állítás a metszéspont kiszámítására vonatkozik.

4. Állítás. $A z f_{i}\left(w_{k}\right)=f_{k}\left(w_{k}\right)$ metszéspont $w_{k}>0$ helye

$$
w_{k}=\frac{d-b_{i}+\sqrt{\left(b_{i}-d\right)^{2}+4 a_{i} c}}{2 a_{i}} .
$$

Bizonyítás. Az (5.10) és (5.11) képleteket (5.16)-ba helyettesítve a következôt kapjuk:

$$
a_{i} w_{k}+b_{i}=\frac{c}{w_{k}}+d
$$

Ezt átrendezve

$$
a_{i} w_{k}^{2}+\left(b_{i}-d\right) w_{k}-c=0 .
$$

A másodfokú megoldóképletet alkalmazva

$$
w_{k}=\frac{d-b_{i} \pm \sqrt{\left(b_{i}-d\right)^{2}+4 a_{i} c}}{2 a_{i}} .
$$


Mivel $\sqrt{\left(b_{i}-d\right)^{2}+4 a_{i} c}>d-b_{i}$ csak a $+\sqrt{\left(b_{i}-d\right)^{2}+4 a_{i} c}$ tagot tartalmazó képlet ad pozitív megoldást.

Az eddig leírtak képezik az algoritmus magját. Pár további részleten kívül, mint a megállási kritérium és az induló értékek, ez már elegendô az implementációhoz. További gyorsítási lehetôségeket is kihasználhatunk, melyek különösen nagy mátrixok esetén lehetnek jelentôsek. Az eredeti célunk is az algoritmus nagy mátrixokra szabása volt. A következô gyorsítási lehetőségek kis mátrixok esetén valószínúleg valójában lassítások, mivel olyan elemeket tartalmaznak, amelyeknek konstans vagy a mérettel lassan növekedô a múveletigényük. Nagy mátrixok esetén azonban ezek már a futásidô elenyészô hányadát teszik ki és a használatukból eredô előnyök már összességében gyorsítást eredményeznek. A konkrét futásidók összehasonlítása folyamatban van.

Figyeljük meg, hogy nem feltétlenül szükséges az összes metszéspontot kiszámolnunk: csak a lineáris függvények maximumának a hiperbolikus függvénnyel vett metszéspontjára van szükségünk. Így azok a lineáris függvények, amelyeknek nincs közös pontja a lineárisak felső burkolójával, érdektelenek. Formálisan, ha létezik $i \neq k$ és $j \neq k$, amelyre $a_{i} \geq a_{j}$ és $b_{i} \geq b_{j}$ az (5.10) képletben, valamint a két egyenlőtlenség közül legalább az egyik szigorú, akkor $f_{i}\left(w_{k}\right)>f_{j}\left(w_{k}\right)$ minden $w_{k}>0$-ra. Így $f_{j}$-nek nem lesz közös pontja $\max _{i \neq k} f_{i}\left(w_{k}\right)$-val, azaz $f_{k}$-nak az $f_{j}$-vel vett metszéspontját nem szükséges kiszámolni.

Szemléletesen ez azt jelenti, hogy ha egy egyenes a pozitív síknegyeden teljes egészében egy másik „felett” halad, akkor a „lejjebb lévô" egyenest elhagyhatjuk. Ilyen pontosan akkor következik be, hogy ha két egyenesnek nincsen a pozitív síknegyedben metszéspontja.

Ha a metszéspontot minden $f_{i}, i \neq k$-ra kiszámolnánk, akkor $n-1$ metszéspontot kellene kiszámolnunk. Ha csak azokra az $f_{i}$-kre számoljuk ki, amelyek nem érdektelenek, akkor potenciálisan jóval kevesebb mint $n-1$ metszéspontot szükséges kiszámolnunk, amely különbség föleg nagy mátri- 


\subsection{DOMINÁNS SAJÁTVEKTOR CIKLIKUS KOORDINÁTÁKKAL 103}

xok esetén lehet látványos.

Térjünk most rá a megállási kritériumra. A megállási kritérium a $\lambda_{\max }$ (5.6) és (5.5) szerinti minimax és maximin tulajdonságát is felhasználja. Minden iteráció végén, $w_{k}$ meghatározása után kiszámoljuk az

$$
f_{i}\left(w_{k}\right)=f_{k}\left(w_{k}\right)=a_{i} w_{k}+b_{i}=\frac{c}{w_{k}}+d=\frac{(A w)_{i}}{w_{i}}=\frac{(A w)_{k}}{w_{k}}
$$

értéket a megfeleló $i$-vel, azaz azzal, amelyikre $f_{i}$-nek az $f_{k}$-val való metszéspontja a legközelebb van 0-hoz. A fenti (5.17) egyenlőség sorozatban az elsố egyenlőség a 3. Állítás miatt igaz, míg az azt követô formák az (5.16) összefüggés átfogalmazásai (5.10), (5.11) illetve (5.8) alapján. Így kapjuk az (5.7)-nek

eleget tevô $w_{k}$ értéket. Az alsó burkoló maximumát, a $\max _{w_{k}^{\prime}} \min _{i=1, \ldots, n} \frac{(A w)_{i}}{w_{i}}$ értéket és az ahhoz tartozó $w_{k}^{\prime}$ pontot is hasonlóan számoljuk, tulajdonképpen a fenti számolások tükörképeivel. Pontosabban az $f_{k}$ hiperbola összes olyan $f_{i}, i \neq k$-val vett metszéspontját, azaz az $f_{k}\left(w_{k}^{\prime}\right)=f_{i}\left(w_{k}^{\prime}\right)$ egyenlóségnek eleget tevô értéket kiszámoljuk, ami minimum értelemben nem érdektelen, azaz amire nincs olyan másik egyenes, ami „alatta” halad. Ezután ezek közül azt a $w_{k}^{\prime}$ értéket választjuk, ami a legnagyobb, azaz ami a legmesszebb van 0-tól. Így $w_{k}^{\prime}$-re

$$
\max _{w_{k}^{\prime}} \min _{i=1, \ldots, n} \frac{(A w)_{i}}{w_{i}}=f_{k}\left(w_{k}^{\prime}\right)
$$

teljesül az aktuális iterációban. Az algoritmus megáll, ha (5.7) és (5.18) közelebb vannak egymáshoz, mint egy elôre meghatározott küszöbérték.

A fentiekból látható, hogy a megállási kritérium ellenôrzése az alsó burkoló maximumának számolása miatt többletszámításokat igényel. Annak érdekében, hogy ezeknek a számításoknak a számát csökkentsük, két fázisra bontjuk az algoritmust. A fenti (5.18) értéket, azaz az alsó burkoló maximumát csak a második fázisban számoljuk. Az elsô fázisban csak (5.7)-et, azaz a felsố burkoló minimumát számoljuk, és azt ellenőrizzük, hogy az előzó iterációban felvett értékéhez képest többet változik-e, mint egy előre meghatározott küszöbérték. Ha igen, akkor a második fázisba lépünk, és onnantól 
kezdve már (5.18)-at is számoljuk, és a két értéket egymással hasonlítjuk össze. A két fázisra bontásnak köszönhetôen az algoritmus elején így nem szükséges az alsó burkoló maximumának számolását is elvégezni: az elsô fázisban csak a felsố burkoló minimumát, a második fázisban mindkét burkoló szélsőértékét kiszámítjuk.

Tisztázásra vár még a kezdőértékek kérdése. Kezdôértéknek elvileg bármely pozitív súlyvektor megfelel. Ha egyszerúen akarunk eljárni, használhatjuk a $w_{i}^{(0)}=1, i=1, \ldots, n$ csupa 1-es kezdôértékeket. Páros összehasonlítás mátrixok esetén azonban, ahol a sajátvektor módszer szerint a domináns sajátvektort (és sajátértéket) keressük, amely közel van a logaritmikus legkisebb négyzetek módszere által adott soronként vett mértani középhez [58]. Így a kezdôértékeket ebben az esetben érdemes a következô módon választani:

$$
w_{i}^{(0)}=\prod_{j=1}^{n} \sqrt[n]{a_{i j}} .
$$

Ezt a kezdőértéket általános pozitív mátrixok esetén is használhatjuk a csupa egyesekből álló kezdőérték helyett.

Szükségünk van még a $w_{i}$ értékek normalizálására is, hogy ne fordulhassanak elô túl nagy vagy túl kicsi számok. A normalizálást több módon is meg lehet tenni, például a $w_{i}$ értékek összegét 1-re beállítani, vagy akár a $w_{1}=1$ módon is. A konkrét implementációban ez utóbbi normalizálás szerepel. A normalizálást minden iteráció végén elvégezzük.

Összefoglalva, a teljes algoritmus a következó lépésekből áll, ahol a .(p) felső index egy függvényt, változót vagy értéket jelöl a $p$-edik iterációban.

1. Beállítjuk a $w_{i}^{(0)}, i=1, \ldots, n$ kezdőértékeket (5.19) alapján. Legyen az iteráció indexe $p=1$, és a fázis legyen az elsô fázis.

2. Legyen az aktuális változó indexe $k=1$.

3. Az aktuális változó $w_{k}^{(p)}$, míg a többi változó értéke rögzítve van a $w_{i}^{(p)}, i=1, \ldots, k-1$ és $w_{i}^{(p-1)}, i=k+1, \ldots, n$ értékeken. 


\subsection{DOMINÁNS SAJÁTVEKTOR CIKLIKUS KOORDINÁTÁKKAL 105}

4. Számoljuk ki $w_{k}^{(p)}$-t úgy, hogy azt az értéket választjuk, amire $f_{k}^{(p)}\left(w_{k}^{(p)}\right)=$ $f_{i}^{(p)}\left(w_{k}^{(p)}\right)$ a legkisebb az összes nem érdektelen $f_{i}^{(p)}$ közül.

5. $k=k+1$. Ha $k<n$, térjünk vissza a 3. lépéshez.

6. Ha az elsó fázisban vagyunk, ellenórizzük $f_{n}^{(p-1)}\left(w_{n}^{(p-1)}\right)-f_{n}^{(p)}\left(w_{n}^{(p)}\right)<T$ teljesülését. Ha a második fázisban vagyunk, ellenőrizzük $f_{n}^{(p)}\left(w_{n}^{(p)}\right)-$ $f_{n}^{(p)}\left(w_{n}^{(p)}\right)<T$ teljesülését. Itt $T$ az elôre meghatározott küszöbérték.

7. Normalizáljunk.

8. Ha a 6. lépésben az ellenôrzés igaz és az elsô fázisban vagyunk, akkor lépjünk a második fázisba és térjünk vissza a 2. lépéshez. Ha az ellenôrzés igaz, és a második fázisban vagyunk, menjünk a 9. lépésre. Ha az ellenôrzés hamis, akkor legyen $p=p+1$ és térjünk vissza a 2. lépéshez.

9. Eredményként adjuk ki a $w_{i}, i=1, \ldots, n$ értékeket a domináns sajátvektor elemeiként és az $f_{k}\left(w_{k}\right)$ értéket a domináns sajátértékként.

A fent leírt algoritmus egy új eljárás a domináns sajátvektor és sajátérték számításra, mely nagy mátrixokra van szabva és egyszerúségét a ciklikus koordináták módszere, valamint az aritmetikailag egyszerú számítások adják. 


\section{6. fejezet}

\section{Összefoglalás}

Az értekezés témája a többszempontú döntéselméletben fontos szerepet játszó páros összehasonlítás mátrixok bemutatása és vizsgálata. A bevezetésben található alapfogalmak és módszerek mellett a 3 . fejezetben egy irodalmi áttekintést is adtam a páros összehasonlítás mátrixok közgazdasági alkalmazásairól, valamint egy ilyen témájú cikket részletesen is bemutattam.

A saját eredmények két fő téma köré csoportosulnak, melyek közül az elsố a Pareto-hatékonyság (4. fejezet). Ebben a témakörben két eredményt sikerült elérnünk a sajátvektor módszer hatékonysági vizsgálatával kapcsolatban. Az eredmények relevanciáját az adja, hogy a sajátvektor módszer igen széles körben alkalmazott, viszont nem minden esetben ad hatékony súlyvektort. Ugyan általánosságban nem számíthatunk a sajátvektor módszer Pareto-hatékonyságára, eredményeink egy speciális, de a gyakorlatban is előforduló mátrixosztály esetén mégis garantálják a hatékonyságot. A szóban forgó speciális mátrixosztály a legfeljebb két elemtôl eltekintve konzisztens páros összehasonlítás mátrixok osztálya. Az eredmény ugyan összefoglalható ilyen egyszerû módon, azonban két lépcsôben sikerült eljutnunk ehhez az eredményhez: először az egy elemtôl eltekintve konzisztens páros összehasonlítás mátrixokra igazoltuk a sajátvektor hatékonyságát (4.1. alfejezet), majd ezt terjesztettük ki a két elemtól eltekintve konzisztens mátrixokra. 
A másik fő témakör szintén a sajátvektor módszerhez tartozik, az eredmények algoritmusok a súlyvektor kiszámítására (5. fejezet). Az elsô (tulajdonképpen két) algoritmus a Newton-módszer segítségével határozza meg nem teljesen kitöltött páros összehasonlítás mátrixok ( $C R$ inkonzisztenciára) optimális kitöltését és domináns sajátértékét (5.1. alfejezet), melyból a súlyvektor, mely a domináns sajátvektor, már számolható. A Newton-módszerrel történő kitöltés két változatát is bevezettem: egy egyváltozós, ciklikus koordinátán alapuló algoritmust (5.1.1. alfejezet), valamint egy többváltozós eljárást (5.1.2. alfejezet).

Ugyanehhez a témakörhöz kapcsolódik az 5.2. alfejezetben bemutatott algoritmus, mely visszatér a kitöltött mátrixok esetére. Ez az algoritmus képes bármely pozitív mátrix, speciálisan páros összehasonlítás mátrixok domináns sajátértékét és sajátvektorát meghatározni egy ciklikus koordinátákon alapuló iteratív eljárással. Ezt az algoritmust úgy alkottuk meg, hogy kifejezetten nagy mátrixokra legyen minél gyorsabb. Mivel az eljárás bármely pozitív mátrixra múködik, ezért potenciálisan a döntéselmélet témakörén kívül is alkalmazható. 


\section{Irodalomjegyzék}

[1] K. Ábele-Nagy. Nem teljesen kitöltött páros összehasonlítás mátrixok a többszempontú döntésekben. Diplomamunka, Eötvös Loránd Tudományegyetem, 2010.

[2] K. Ábele-Nagy. Minimization of the Perron eigenvalue of incomplete pairwise comparison matrices by Newton iteration. Acta Universitatis Sapientiae, Informatica, 7(1):58-71, 2015.

[3] K. Ábele-Nagy and S. Bozóki. Efficiency analysis of simple perturbed pairwise comparison matrices. Fundamenta Informaticae, 144:279-289, 2016.

[4] K. Ábele-Nagy, S. Bozóki, and Ö. Rebák. Efficiency analysis of double perturbed pairwise comparison matrices. Journal of the Operational Research Society, 69(5):707-713, 2018.

[5] K. Ábele-Nagy and J. Fülöp. On computing the principal eigenvector of positive matrices by the method of cyclic coordinates. kézirat, 2019.

[6] J. Aczél and T. Saaty. Procedures for synthesizing ratio judgements. Journal of Mathematical Psychology, 27(1):93-102, 1983.

[7] J. Aguarón and J. M. Moreno-Jiménez. The geometric consistency index: Approximated thresholds. European Journal of Operational Research, 147(1):137-145, 2003. 
[8] G. Bajwa, E. U. Choo, and W. C. Wedley. Effectiveness analysis of deriving priority vectors from reciprocal pairwise comparison matrices. Asia-Pacific Journal of Operational Research, 25(3):279-299, 2008.

[9] R. Blanquero, E. Carrizosa, and E. Conde. Inferring efficient weights from pairwise comparison matrices. Mathematical Methods of Operations Research, 64(2):271-284, 2006.

[10] S. Bozóki and V. Tsyganok. The logarithmic least squares optimality of the geometric mean of weight vectors calculated from all spanning trees for (in)complete pairwise comparison matrices. kézirat, 2017. https: //arxiv.org/pdf/1701.04265.pdf.

[11] S. Bozóki. Inefficient weights from pairwise comparison matrices with arbitrarily small inconsistency. Optimization, 63(12):1893-1901, 2014.

[12] S. Bozóki, J. Fülöp, and L. Rónyai. On optimal completion of incomplete pairwise comparison matrices. Mathematical and Computer Modelling, 52(1-2):318-333, 2010.

[13] S. Bozóki, J. Fülöp, and A. Poesz. On pairwise comparison matrices that can be made consistent by the modification of a few elements. Central European Journal of Operations Research, 19(2):157-175, 2011.

[14] M. Brunelli, L. Canal, and M. Fedrizzi. Inconsistency indices for pairwise comparison matrices: a numerical study. Annals of Operations Research, 211(1):493-509, 2013.

[15] M. Brunelli and M. Fedrizzi. Axiomatic properties of inconsistency indices for pairwise comparisons. Journal of the Operational Research Society, 66(1):1-15, 2015.

[16] J. Buckley. Fuzzy hierarchical analysis. Fuzzy Sets and Systems, 17(3):233-247, dec 1985. 
[17] K. Chen, G. Kou, J. M. Tarn, and Y. Song. Bridging the gap between missing and inconsistent values in eliciting preference from pairwise comparison matrices. Annals of Operations Research, 235(1):155-175, 2015.

[18] E. Choo and W. Wedley. A common framework for deriving preference values from pairwise comparison matrices. Computers \& Operations Research, 31(6):893-908, 2004.

[19] E. U. Choo, B. Schoner, and W. C. Wedley. Interpretation of criteria weights in multicriteria decision making. Computers $\&$ Industrial Engineering, 37(3):527-541, 1999.

[20] A. T. W. Chu, R. E. Kalaba, and K. Spingarn. A comparison of two methods for determining the weights of belonging to fuzzy sets. Journal of Optimization Theory and Applications, 27(4):531-538, 1979.

[21] E. Conde and M. d. 1. P. R. Pérez. A linear optimization problem to derive relative weights using an interval judgement matrix. European Journal of Operational Research, 201(2):537-544, 2010.

[22] W. Cook and M. Kress. Deriving weights from pairwise comparison ratio matrices: An axiomatic approach. European Journal of Operational Research, 37(3):355-362, 1988.

[23] G. Crawford and C. Williams. A note on the analysis of subjective judgment matrices. Journal of Mathematical Psychology, 29(4):387-405, 1985.

[24] L. Csató. Ranking by pairwise comparisons for swiss-system tournaments. Central European Journal of Operations Research, 21(4):783803, 2012.

[25] L. Csató. Felsőoktatási rangsorok jelentkezôi preferenciák alapján. Közgazdasági Szemle, 63:27-61, 2016. 
[26] L. Csató. Characterization of an inconsistency measure for pairwise comparison matrices. Annals of Operations Research, 261(1-2):155-165, 2017.

[27] J. G. de Graan. Extensions of the multiple criteria analysis method of T.L. Saaty. Technical report, National Institute for Water Supply, Leidschendam, The Netherlands, 1980.

[28] P. de Jong. A statistical approach to Saaty's scaling method for priorities. Journal of Mathematical Psychology, 28(4):467-478, 1984.

[29] Sz. Duleba. Szeméyes kommunikáció, 2018.

[30] Sz. Duleba, T. Mishina, and Y. Shimazaki. A dynamic analysis on public bus transport's supply quality by using AHP. Transport, 27(3):268-275, 2012.

[31] Z. Duszak and W. W. Koczkodaj. Generalization of a new definition of consistency for pairwise comparisons. Information Processing Letters, 52(5):273-276, 1994.

[32] C. A. B. E Costa and J.-C. Vansnick. MACBETH - an interactive path towards the construction of cardinal value functions. International Transactions in Operational Research, 1(4):489-500, 1994.

[33] M. Ehrgott. Multicriteria Optimization. volume 491 of Lecture Notes in Economics and Mathematical Systems. Springer Verlag, Berlin, 2000.

[34] A. Farkas. The analysis of the principal eigenvector of pairwise comparison matrices. Acta Polytechnica Hungarica, 4(2):99-115, 2007.

[35] A. Farkas, P. Rózsa, and E. Stubnya. Transitive matrices and their applications. Linear Algebra and its Applications, 302-303:423-433, 1999. 
[36] M. Fedrizzi. Obtaining non-dominated weights from preference relations through norm-induced distances. XXXVII Meeting of the Italian Association for Mathematics Applied to Economic and Social Sciences (AMASES), September 5-7, 2013, Stresa, Italy, 2013.

[37] J. Fichtner. Some thoughts about the mathematics of the analytic hierarchy process. Inst. für Angewandte Systemforschung u. OperationsResearch, 1984.

[38] J. Fichtner. On deriving priority vectors from matrices of pairwise comparisons. Socio-Economic Planning Sciences, 20(6):341-345, 1986.

[39] J. Fülöp. A sajátvektor módszer egy optimalizálási megközelítése. XXX. Magyar Operációkutatási Konferencia, 2013.

[40] S. Gass and T. Rapcsák. Singular value decomposition in AHP. European Journal of Operational Research, 154(3):573-584, 2004.

[41] L. Gáspár. A mérnökök hozzájárulása a túlélés szellemi kör célkitúzéseinek eléréséhez. Magyar Tudomány, 9:1126-1129, 2013.

[42] P. Harker. Incomplete pairwise comparisons in the Analytic Hierarchy Process. Mathematical Modelling, 9(11):837-848, 1987.

[43] P. T. Harker. Derivatives of the Perron root of a positive reciprocal matrix: With application to the Analytic Hierarchy Process. Applied Mathematics and Computation, 22(2-3):217-232, 1987.

[44] W. Ho. Integrated analytic hierarchy process and its applications - a literature review. European Journal of Operational Research, 186(1):211$228,2008$.

[45] R. C. V. D. Honert and F. A. Lootsma. Group preference aggregation in the multiplicative AHP the model of the group decision process and Pa- 
reto optimality. European Journal of Operational Research, 96(2):363370, jan 1997.

[46] C.-L. Hwang and K. Yoon. Methods for Multiple Attribute Decision Making. Springer, Berlin, Heidelberg, 1981.

[47] A. Ishizaka and M. Lusti. How to derive priorities in AHP: a comparative study. Central European Journal of Operations Research, 14(4):387-400, 2006.

[48] A. Ishizaka and P. Nemery. Multi-criteria Decision Analysis: Methods and Software. Wiley, 2013.

[49] R. Jensen. Comparison of eigenvector, least squares, chi square and logarithmic least squares methods of scaling a reciprocal matrix. Trinity University, Working Paper 127, 1983.

[50] R. E. Jensen. An alternative scaling method for priorities in hierarchical structures. Journal of Mathematical Psychology, 28(3):317-332, 1984.

[51] R. L. Keeney and H. Raiffa. Decisions with multiple objectives: preferences and value trade-offs. Cambridge University Press, 1993.

[52] W. W. Koczkodaj. A new definition of consistency of pairwise comparisons. Mathematical and Computer Modelling, 18(7):79-84, 1993.

[53] W. W. Koczkodaj and J.-P. Magnot. Axiomatization of inconsistency indicators for pairwise comparisons matrices revisited. kézirat, 2017. https://arxiv.org/pdf/1509.03781.pdf.

[54] W. W. Koczkodaj and R. Szwarc. On axiomatization of inconsistency indicators for pairwise comparisons. Fundamenta Informaticae, 132(4):485-500, 2014. 
[55] G. Kou and C. Lin. A cosine maximization method for the priority vector derivation in AHP. European Journal of Operational Research, 235(1):225-232, 2014.

[56] K. Kułakowski. Heuristic rating estimation approach to the pairwise comparisons method. Fundamenta Informaticae, 133(4):367-386, 2014.

[57] K. Kułakowski. Notes on the existence of a solution in the pairwise comparisons method using the heuristic rating estimation approach. Annals of Mathematics and Artificial Intelligence, 77(1):105-121, 2016.

[58] M. Kwiesielewicz. The logarithmic least squares and the generalized pseudoinverse in estimating ratios. European Journal of Operational Research, 93(3):611-619, 1996.

[59] M. Kwiesielewicz and E. van Uden. Ranking decision variants by subjective paired comparisons in cases with incomplete data. In Computational Science and Its Applications - ICCSA 2003, pages 208-215. Springer Berlin Heidelberg, 2003.

[60] D. G. Luenberger and Y. Ye. Linear and Nonlinear Programming, volume 116 of International Series in Operations Research 85 Management Science. Springer, 3rd edition, 2008.

[61] M. Lundy, S. Siraj, and S. Greco. The mathematical equivalence of the ,spanning tree" and row geometric mean preference vectors and its implications for preference analysis. European Journal of Operational Research, 257(1):197-208, 2017.

[62] É. Orbán-Mihálykó, C. Mihálykó, and L. Koltay. A generalization of the Thurstone method for multiple choice and incomplete paired comparisons. Central European Journal of Operations Research, 2017. 
[63] D. Petróczy. Egy életminôség-rangsor a hazautalások alapján. kézirat, 2018.

[64] A. Poesz. Inkonzisztencia a döntéshozatalban. Ph.D. értekezés, Budapesti Corvinus Egyetem, Általános és Kvantitatív Közgazdaságtan Doktori Iskola, 2018.

[65] M. A. Pöyhönen, R. P. Hämäläinen, and A. A. Salo. An experiment on the numerical modelling of verbal ratio statements. Journal of MultiCriteria Decision Analysis, 6(1):1-10, 1997.

[66] G. Rabinowitz. Some comments on measuring world influence. Journal of Peace Science, 2(1):49-55, feb 1976.

[67] R. Ramanathan and L. S. Ganesh. Group preference aggregation methods employed in AHP: An evaluation and an intrinsic process for deriving members' weightages. European Journal of Operational Research, 79(2):249-265, dec 1994.

[68] T. Rapcsák. Többszempontú döntési problémák. 2007. http://www. oplab.sztaki.hu/tanszek/download/I_Tobbsz_dont_modsz.pdf.

[69] T. L. Saaty. A scaling method for priorities in hierarchical structures. Journal of Mathematical Psychology, 15(3):234-281, 1977.

[70] T. L. Saaty. The Analytic Hierarchy Process. McGraw-Hill, 1980.

[71] T. L. Saaty. How to make a decision: The analytic hierarchy process. European Journal of Operational Research, 48(1):9-26, 1990.

[72] T. L. Saaty. Fundamentals of decision making. Pittsburgh: RWS Publications, 1994.

[73] T. L. Saaty. The Analytic Network Process: Decision Making With Dependence and Feedback. RWS Publications, 2nd edition, 2001. 
[74] T. L. Saaty and L. G. Vargas. Models, Methods, Concepts \&3 Applications of the Analytic Hierarchy Process. Springer Science \& Business Media, 2012. Google-Books-ID: 6J9XI8I1qjwC.

[75] S. Shiraishi, T. Obata, and M. Daigo. Properties of a positive reciprocal matrix and their application to AHP. Journal of the Operations Research Society of Japan, 41(3):404-414, 1998.

[76] R. E. Steuer. Multiple Criteria Optimization: Theory, Computation, and Application. Wiley Series in Probability and Mathematical Statistics. Wiley, 1986.

[77] R. E. Steuer and P. Na. Multiple criteria decision making combined with finance: A categorized bibliographic study. European Journal of Operational Research, 150(3):496-515, 2003.

[78] N. Subramanian and R. Ramanathan. A review of applications of analytic hierarchy process in operations management. International Journal of Production Economics, 138(2):215-241, 2012.

[79] A. Telcs, Z. T. Kosztyán, and Á. Török. Hallgatói preferencia-sorrendek készítése az egyetemi jelentkezések alapján. Közgazdasági Szemle, 60(3):290, 2013.

[80] A. Telcs, Z. T. Kosztyán, and Á. Török. Unbiased one-dimensional university ranking - application-based preference ordering. Journal of Applied Statistics, 43(1):212-228, 2015.

[81] J. Temesi. A döntéselmélet alapjai. Aula Kiadó, 2002.

[82] V. Tsyganok. Combinatorial method of pairwise comparisons with feedback. Data Recording, Storage \& Processing, 2:92-102, 2000 (ukrán nyelven). 
[83] V. Tsyganok. Investigation of the aggregation effectiveness of expert estimates obtained by the pairwise comparison method. Mathematical and Computer Modelling, 52(3-4):538-544, 2010.

[84] V. R. Tummala and H. Ling. A note on the computation of the mean random consistency index of the analytic hierarchy process (AHP). Theory and Decision, 44(3):221-230, 1998.

[85] O. S. Vaidya and S. Kumar. Analytic hierarchy process: An overview of applications. European Journal of Operational Research, 169(1):1-29, 2006.

[86] P. van Laarhoven and W. Pedrycz. A fuzzy extension of Saaty's priority theory. Fuzzy Sets and Systems, 11(1-3):229-241, 1983.

[87] L. G. Vargas. An overview of the analytic hierarchy process and its applications. European Journal of Operational Research, 48(1):2-8, 1990.

[88] P. Vincke. Multicriteria Decision-Aid. John Wiley \& Sons Inc., 1992.

[89] W. C. Wedley. Consistency prediction for incomplete AHP matrices. Mathematical and Computer Modelling, 17(4-5):151-161, 1993. 